\title{
COMPOSIÇÃO FLORÍSTICA DA COMUNIDADE DE LIANAS LENHOSAS EM DUAS FORMAÇÕES FLORESTAIS DO ESTADO DE SÃO PAULO
}

\author{
RENATA GIASSI UDULUTSCH
}

Dissertação apresentada à Escola Superior de Agricultura "Luiz de Queiroz", Universidade de São Paulo, para obtenção do título de Mestre em Ecologia de Agroecossistemas.

P I R A C I C A B A

Estado de São Paulo - Brasil

Janeiro - 2004 


\title{
COMPOSIÇÃO FLORÍSTICA DA COMUNIDADE DE LIANAS LENHOSAS EM DUAS FORMAÇÕES FLORESTAIS DO ESTADO DE SÃO PAULO
}

\author{
RENATA GIASSI UDULUTSCH
}

Bióloga

Orientador: Prof. Dr. VINICIUS CASTRO SOUZA

Dissertação apresentada à Escola Superior de Agricultura "Luiz de Queiroz", Universidade de São Paulo, para obtenção do título de Mestre em Ecologia de Agroecossistemas.

P I R A C I C A B A

Estado de São Paulo - Brasil

Janeiro - 2004 
Dados Internacionais de Catalogação na Publicação (CIP)
DIVISÃO DE BIBLIOTECA E DOCUMENTAÇÃO - ESALQ/USP

Udulutsch, Renata Giassi

Composição florística da comunidade de lianas lenhosas em duas formações

florestais do Estado de São Paulo / Renata Giassi Udulutsch. - - Piracicaba, 2004.

114 p. : il.

Dissertação (mestrado) - - Escola Superior de Agricultura Luiz de Queiroz, 2004.

Bibliografia.

1. Composição florística 2. Morfologia vegetal 3. Parques florestais 4. Plantas (identificação) 5. Trepadeira I. Título

CDD 582.18

\section{"Permitida a cópia total ou parcial deste documento, desde que citada a fonte - O autor"}




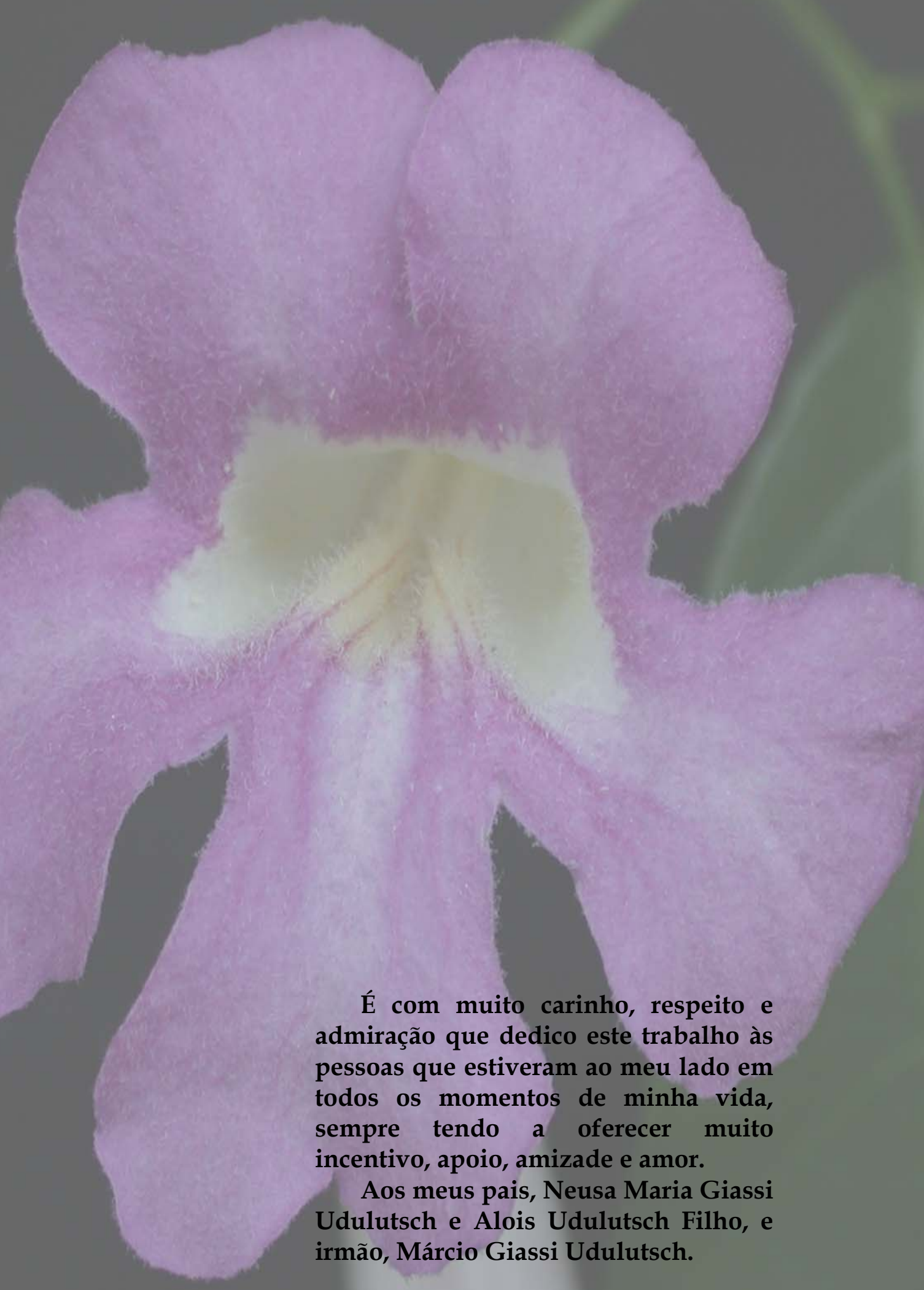




\section{SUMÁRIO}

Página

LISTA DE FIGURAS............................................................................... viii

LISTA DE TABELAS............................................................................. ix

RESUMO

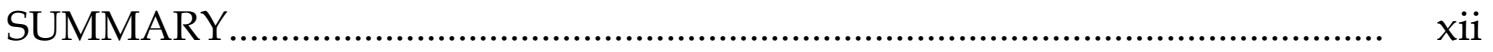

1 INTRODUÇÃ

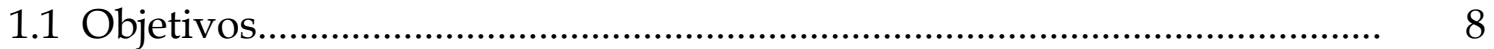

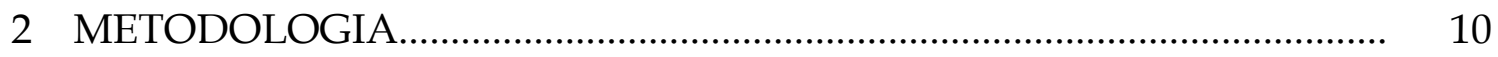

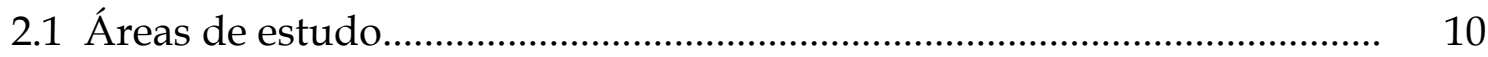

2.1.1 Estação Ecológica dos Caetetus............................................................... 10

2.1.2 Parque Estadual Carlos Botelho........................................................ 11

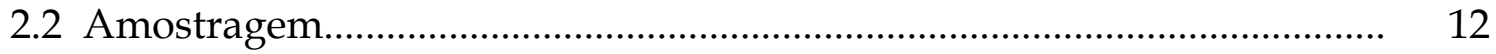

2.3 Produção do guia ilustrado de identificação............................................. 19

3 RESULTADOS E DISCUSSÃO.............................................................. 21

3.1 Composição florística............................................................................. 21

3.2 Adaptações morfológicas desenvolvidas pelas lianas............................... 29

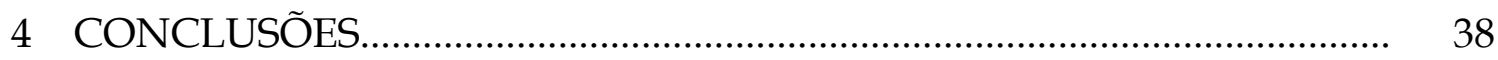

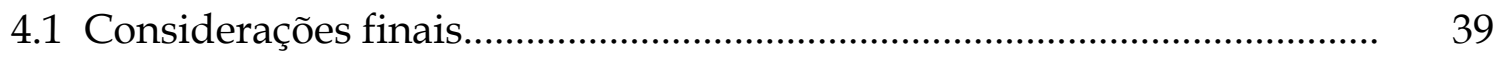

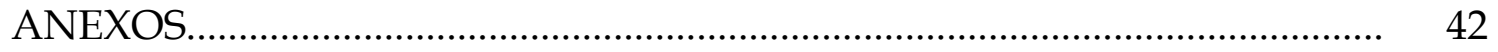

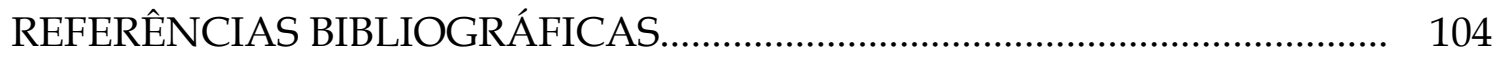

BIBLIOGRAFIA RECOMENDADA......................................................... 113 


\section{LISTA DE FIGURAS}

Página

1 Mapa de localização das duas áreas de estudo no Estado de São Paulo

2 Sub-parcelas sorteadas para a realização do levantamento florístico

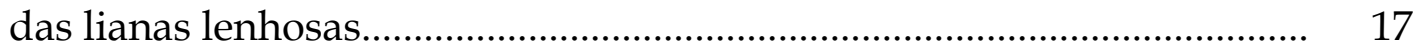

3 Aspecto geral da vegetação na Estação Ecológica dos Caetetus................. 18

4 Aspecto geral da vegetação no Parque Estadual Carlos Botelho................ 19

5 Famílias mais representativas segundo o número de espécies de lianas lenhosas, ocorrentes na área amostrada da Estação Ecológica

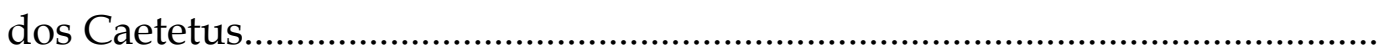

6 Famílias mais representativas segundo o número de espécies de lianas lenhosas, ocorrentes na área amostrada do Parque Estadual Carlos Botelho 


\section{LISTA DE TABELAS}

Página

1 Listagem das espécies de lianas lenhosas ocorrentes na área amostrada da Estação Ecológica dos Caetetus (No. do COLETOR = R. G. Udulutsch)

2 Listagem das espécies de lianas lenhosas ocorrentes na área amostrada do Parque Estadual Carlos Botelho (No. do COLETOR = R. G. Udulutsch).

3 Número de espécies de lianas em florestas tropicais úmidas.

4 Listagem das espécies de lianas lenhosas amostradas na Estação Ecológica dos Caetetus e respectivas formas de escalada.

5 Listagem das espécies de lianas lenhosas amostradas no Parque Estadual Carlos Botelho e respectivas formas de escalada...........................

6 Classificação e quantificação das lianas lenhosas, de acordo com o tipo de fixação, para a Estação Ecológica dos Caetetus e para o Parque Estadual Carlos Botelho. 


\title{
COMPOSIÇÃO FLORÍSTICA DA COMUNIDADE DE LIANAS LENHOSAS EM DUAS FORMAÇÕES FLORESTAIS DO ESTADO DE SÃO PAULO
}

\author{
Autora: RENATA GIASSI UDULUTSCH \\ Orientador: Prof. Dr. VINICIUS CASTRO SOUZA
}

\section{RESUMO}

Tendo em vista a necessidade de se estudar as formações florestais do Estado de São Paulo de forma mais detalhada, a fim de que sua composição florística seja definida e seu processo de dinâmica compreendido, este estudo tem como objetivos principais: levantar e identificar as espécies de lianas lenhosas ocorrentes em um trecho de Floresta Ombrófila Densa do Parque Estadual Carlos Botelho (P.E.C.B.) e outro de Floresta Estacional Semidecídua da Estação Ecológica dos Caetetus (E.E.C.) e produzir um guia ilustrado de campo incluindo fotografias e diagnoses para as espécies de lianas lenhosas encontradas nas sub-parcelas amostradas e chaves de identificação baseadas em caracteres vegetativos. Foram sorteadas, para as duas áreas, 50 sub-parcelas de $20 \times 20$ m das 256 pertencentes ao projeto temático "Diversidade, dinâmica e conservação de florestas no Estado de São Paulo: 40 ha de parcelas permanentes". Também foram realizadas coletas aleatórias por trilhas e na borda dos fragmentos. Foram consideradas lianas todas as plantas que 
necessitavam de um suporte para o seu desenvolvimento e que mantinham contato permanente com o solo. Foram encontradas 76 espécies de lianas lenhosas para a E.E.C., distribuídas por 52 gêneros e 19 famílias e, para o P.E.C.B., 49 espécies, 40 gêneros e 19 famílias. Em campo e no laboratório foram feitos os registros fotográficos para cada espécie de liana, incluindo detalhes importantes para sua identificação. Com esses dados foi elaborado um guia ilustrado de identificação para as lianas lenhosas. Quanto aos mecanismos de fixação, na E.E.C. a forma preênsil esteve presente na maioria das espécies (57\%) e no P.E.C.B. a forma volúvel foi a que apresentou maior destaque, estando presente em $45 \%$ das espécies amostradas, o que reforça as indicações de que em regiões neotropicais, um dos fatores que está relacionado ao sucesso adaptativo das lianas refere-se às especializações nos mecanismos de fixação ao forófito. 


\title{
FLORISTIC COMPOSITION OF THE WOODY LIANA COMMUNITY IN TWO FOREST FORMATIONS OF SÃO PAULO STATE
}

\author{
Author: RENATA GIASSI UDULUTSCH \\ Adviser: Prof. Dr. VINICIUS CASTRO SOUZA
}

\section{SUMMARY}

Having in mind the necessity of a detailed study of the forest formations in São Paulo State, in order that its floristic composition is defined and its dynamic process is understood, this study have as main goals: a survey and identification of the woody liana species in a Tropical Rain Forest at Parque Estadual Carlos Botelho (P.E.C.B.) and in a Seasonal Semideciduous Forest at Estação Ecológica dos Caetetus (E.E.C.), and a field illustrated guide with photographs, diagnoses and identification keys based on vegetative characters for woody liana species of the sub-plots sampled. For the two areas, 50 sub-plots of $20 \times 20 \mathrm{~m}$ were chosen at random among 256 of the tematic project "Diversity, dinamic and conservation of forests in the São Paulo State: 40 ha of permanente plots". Random collections were made in trails and border of the remnants. It was considered "liana" as climbing plants that maintained permanent contact with the ground. Seventy six woody liana species were found at E.E.C., grouped in 52 genera and 19 families and, at P.E.C.B., 49 
species, 40 genera and 19 families were found. Photographs were taken in the field and at the laboratory for each liana species, with essential characters useful for its determination. With these data a field illustrated guide was produced for the woody lianas. As for climbing strategies, seizing was the most common technique for the majority of species (57\%) at E.E.C. and, at P.E.C.B., the twining form was most representative, in $45 \%$ of the sampled species, evidencing that, in neotropical regions, one of the factors related to the adaptative success of the lianas refers to their specialization in the climbing methods. 


\section{INTRODUÇÃO}

Os biomas brasileiros vêm passando por uma série de transformações estruturais e funcionais, ligadas às atividades antrópicas que se sobrepõem aos eventos naturais, interferindo tanto nas relações intra e interespecíficas quanto no processo evolutivo, pois as formações vegetais estão sendo cada vez mais reduzidas e os remanescentes ficando cada vez mais isolados. Tendo em vista esses aspectos e sabendo da importância do papel desempenhado por cada espécie em uma comunidade, percebe-se o quanto é significativa a realização de pesquisas que mostrem, em um primeiro momento, a composição florística e como as várias formas de vida estão estruturadas para compreendermos como é construída a relação de interdependência entre os indivíduos e destes com o ambiente. Desta forma, poderemos interferir no sentido de determinar diretrizes mais seguras para conservar os remanescentes florestais, além de estabelecer medidas racionais de manejo.

O Brasil está entre os países mais ricos em termos de biodiversidade, detendo cerca de $20 \%$ das espécies de fanerógamas (Piliackas, 2001), as quais distribuem-se pelos vários tipos vegetacionais que aqui ocorrem: florestas pluviais, como a Amazônica e a Atlântica; florestas deciduais, como a Caatinga e o Cerrado e Pradarias e Florestas Subtropicais do sul do país.

Entre as principais formações florestais ocorrentes no Estado de São 
Paulo destacam-se as Formações Pioneiras com Influência Marinha (Floresta de Restinga), a Floresta Ombrófila Densa (Floresta Atlântica de Encosta), a Floresta Estacional Semidecidual e a Savana Florestada (Cerradão) (Veloso \& Goés Filho, 1982). Mas poucos são os remanescentes que abrangem uma maior área e, além disso, que apresentem baixa intensidade de perturbações, o que normalmente está relacionado à dificuldade de acesso e/ou à dificuldade de realização de alguma prática rentável. Dentre esses estão os dois remanescentes selecionados para a realização deste trabalho, localizados nos municípios de Sete Barras (Floresta Atlântica de Encosta) e Gália (Floresta Estacional Semidecídua).

Embora seja aceito que florestas tropicais com alta pluviosidade são aquelas mais ricas em termos de espécies vegetais (Cain \& Castro, 1959), a base para tal afirmação restringe-se basicamente ao componente arbóreo (Silva \& Leitão Filho, 1982; Pagano \& Leitão Filho, 1987; Rodrigues et al., 1989; Grombone et al., 1990; Tabarelli \& Mantovani, 1999), pouco se relatando sobre as lianas, mesmo sendo estas responsáveis por grande parte da diversidade biológica das florestas, podendo representar 35\% do número de espécies de plantas vasculares (Gentry \& Dodson, 1987). Essa escassez de trabalhos sobre lianas deve estar associada à alta diversidade taxonômica do grupo e às dificuldades metodológicas para a coleta de dados no dossel.

A competição pela luz é um dos fatores de maior importância na determinação da fisionomia das florestas tropicais (Hegarty \& Caballé, 1991). Os diferentes grupos de plantas desenvolveram adaptações próprias para a obtenção de luz, sendo a mais óbvia apresentada pelas árvores, onde ocorre o desenvolvimento de um sistema caulinar que leva as folhas a grandes alturas, geralmente com grande investimento de recursos na sustentação. Uma vez presentes estas árvores, existem duas outras possibilidades de acesso à luminosidade: o direto estabelecimento de plantas sobre o tronco, galhos ou folhas de outros vegetais, o qual é realizado pelas epífitas, ou ainda um rápido 
crescimento em altura, não havendo grande investimento de recursos em sustentação (Darwin, 1897; Hora, 1999). Esta última forma de maximizar a captação de luz, através da busca pelo dossel, foi desenvolvida pelas lianas.

Menninger (1970) menciona que não é simples estabelecer uma classificação para as lianas. Richards (1952) e Gentry (1985) separam essas plantas em dois grupos: lianas, como sendo aquelas quase sempre lenhosas e de grande porte, capazes de se desenvolver em florestas maduras e trepadeiras herbáceas, que são restritas à vegetação rasteira e ambiente de sombra, crescendo geralmente em áreas perturbadas ou em bordas de florestas. O termo trepadeiras (climbers) foi empregado por diversos autores tanto para as lenhosas como para herbáceas (Gentry, 1991; Opler, Baker \& Frankie, 1991; Morellato \& Leitão Filho, 1998).

Cada definição para forma de vida envolve uma série de conceitos morfológicos, ecológicos e ontogenéticos (Kelly, 1985). Veloso (1992) adaptou o sistema de classificação das formas de vida terrestre de Raunkiaer ${ }^{1}$ (citado por Veloso, 1992) para a vegetação brasileira, definindo 10 classes, onde uma delas é a de lianas. De acordo com esse sistema, lianas são plantas herbáceas ou lenhosas que vivem apoiadas em outra planta ou substrato, cujas gemas, acima do solo, são protegidas por catáfilos.

Segundo Putz \& Windsor (1987), lianas são plantas cujo crescimento em altura depende da sustentação mecânica fornecida por outras plantas. Partindo deste princípio, Hegarty (1991) classificou essas plantas segundo suas técnicas usuais de escalada em:

1. Volúveis: que utilizam o caule, ramos ou pecíolos/peciólulos para se enrolarem;

1 VELOSO, H. P. Sistema fitogeográfico. In: FUNDAÇÃO INSTITUTO BRASILEIRO DE GEOGRAFIA E ESTATÍSTICA. Manual Técnico da Vegetação Brasileira. Rio de Janeiro: IBGE, 1992. p.9-38. (Manuais Técnicos em Geociências, 1). 
2. Preênseis: apresentam gavinhas, incluindo as gavinhas foliares;

3. Escandentes: freqüentemente auxiliadas por ganchos (ramos curvos que acabam auxiliando na fixação) que evitam a queda;

4. Radicantes: aquelas que se utilizam de raízes adventícias.

A classificação proposta por Lima et al. (1997) difere da apresentada anteriormente quanto à definição das plantas escandentes e daquelas com órgãos preensores. As escandentes apóiam passivamente sobre o forófito e galgam o suporte sem qualquer mecanismo sensível de aderência; a fixação se faz através do alongamento de ramos laterais divaricados ou por dispositivos morfológicos, como os espinhos. As preensoras possuem sensibilidade localizada na região de aderência ao suporte, sendo que esses órgãos preensores podem ser de natureza foliar ou caulinar. Entre as estruturas de natureza foliar estão os pecíolos e peciólulos dotados de sensibilidade, como ocorre em Ranunculaceae, gavinha filiforme na bainha foliar, como ocorre em Smilacaceae, raque foliar prolongada em gavinhas ramificadas, como ocorre em Mutisia (Asteraceae) e as gavinhas filiformes, justapostas às folhas, como ocorre em Cucurbitaceae ou como substituição ao folíolo, em algumas Bignoniaceae. De natureza caulinar podem ser citados os ramos curtos laterais, de aspecto normal, porém com nós e entrenós que funcionam como estrutura preensora (ganchos), como ocorre em Hippocrateaceae, Leguminosae e Polygalaceae. Outras diferenciações, ainda de origem caulinar, são gavinhas elásticas originadas de um pedúnculo homólogo ao das inflorescências de algumas espécies de Sapindaceae e Leguminosae (Bauhinia), gavinhas originadas a partir da axila, junto com o pedúnculo da inflorescência e o pecíolo, em Passifloraceae, e, finalmente, as gavinhas opostas às folhas em Vitaceae.

Os mecanismos de fixação são evidentemente muito diversificados e certas espécies apresentam simultaneamente características que permitem 
incluí-las em mais de uma categoria.

Além das diferenciações nos mecanismos de escalada, muitas lianas apresentam uma série de modificações durante o desenvolvimento, desde o estágio de plântula até o reprodutivo. Em muitos casos as mudanças são sutis, envolvendo tamanho do internó ou pequenas mudanças no tamanho e forma das folhas. Em outros, as mudanças são profundas, tanto que muitas vezes uma determinada espécie pode receber, erroneamente, identificações diferentes segundo o estágio de desenvolvimento em que se encontra (Lee \& Richards, 1991). Isso fez com que Goebel ${ }^{2}$ (citado por Lee \& Richards, 1991) passasse a reconhecer duas formas de desenvolvimento: homoblástica, para o primeiro caso, e heteroblástica, para o segundo. Os fatores que podem estar atuando, afetando o curso das mudanças no desenvolvimento, são muitos, podendo ser, inclusive, de natureza intrínseca ou não, como a gravidade, estimulação tátil, temperatura, disponibilidade hídrica e luz (Lee \& Richards, 1991). Embora todos esses parâmetros ambientais possam afetar o desenvolvimento heteroblástico das lianas, a luz (tanto em qualidade, quanto em quantidade) é o que apresenta maior influencia na fase de mudanças (Lee \& Richards, 1991). Segundo os mesmos autores, a arquitetura dos ramos e a disposição das folhas em plantas com adaptações ao desenvolvimento em áreas sombreadas, permitem a minimização da própria sombra, caso contrário, as folhas situadas em uma posição inferior na planta não teriam radiação suficiente para a fotossíntese.

A relação liana-forófito pode ser vista, em um primeiro momento, como a mesma definida por Waechter (1992) para epífita-forófito, onde existe uma relação comensal, em que uma espécie beneficia-se do suporte proporcionado

2 LEE, D.W.; RICHARDS, J.H. Heteroblastic development in vines. In: PUTZ, F.E.; MOONEY, H.A. The biology of vines. Cambridge: Cambridge University Press, 1991. p.205-243. 
por uma espécie hospedeira (forófito), a qual não é prejudicada por estruturas haustoriais. No entanto, as lianas crescem geralmente em direção ao dossel, sombreando as árvores hospedeiras e competindo com estas por luz, água e nutrientes (Gentry, 1991). Com isso, as taxas de crescimento e mortalidade das árvores são alteradas (Putz \& Chai, 1987), o que pode atuar como uma importante força seletiva na evolução do componente arbóreo em matas tropicais (Putz, 1984). Segundo Stevens (1987), podem ser consideradas como "parasitas estruturais" das árvores, pois afetam negativamente a reprodução de sua hospedeira. Por outro lado, além das lianas estarem entre os componentes estruturais do habitat de diversos animais, são de grande importância para estes como recurso alimentar (Emmons \& Gentry, 1983; Morellato \& Leitão Filho, 1996). Uma alta capacidade competitiva proporcionada pelas suas características de crescimento e regeneração, associada a condições favoráveis de crescimento, possibilitaram às lianas um sucesso adaptativo nos trópicos provavelmente quase tão grande quanto o de árvores (Engel, Fonseca \& Oliveira, 1998).

O hábito lianescente aparentemente evoluiu de forma independente nos táxons, incluindo as "Gimnospermas", Liliopsida, Magnoliopsida (Putz, 1984) e também nas "Pteridófitas". Segundo Schenck (1892-3, apud Richards, 1952) aproximadamente metade das famílias de plantas vasculares contém espécies de lianas. Famílias como Menispermaceae, Smilacaceae, Cucurbitaceae, Aristolochiaceae, Passifloraceae e Dioscoreaceae são compostas quase que exclusivamente por espécies com esse hábito (Cronquist, 1981).

As lianas são, do ponto de vista geográfico, desigualmente distribuídas. A grande maioria das espécies lenhosas é restrita às florestas tropicais (Croat, 1978). Segundo Jacobs (1976) 8\% de todas as espécies de plantas tropicais são lianas e, considerando a flora neotropical, 10\% das espécies apresentam o hábito lianescente (Gentry, 1991). 
Devido à maior diversidade e abundância de lianas ocorrer em florestas tropicais, onde são membros característicos (Richards, 1952; Gentry, 1991; Peñalosa, 1984; Putz, 1984) acabam constituindo um importante componente florístico, estrutural e funcional nestas florestas (Gentry, 1991). Fatores naturais, incluindo os físico-climáticos, e antrópicos, como a abertura de clareiras, podem influenciar na diversidade florística de lianas (Leitão Filho, 1995; Rezende, 1997). No entanto, clareiras não devem ser consideradas apenas como indicativo de perturbações antrópicas, mas sim como parte integrante da dinâmica de uma floresta, onde são formadas pela freqüente e natural queda das árvores, dando início, assim, às sucessões pontuais. Mas, em matas onde as perturbações são mais freqüentes, o número de clareiras tanto naturais quanto artificiais também é maior, o que acaba levando a um desequilíbrio dessa comunidade, havendo um grande aumento do número de espécies de lianas e/ou, o que é mais freqüente, do número de indivíduos das espécies que são mais agressivas, que afetam negativamente o desenvolvimento do estrato arbóreo e que, portanto, necessitam de manejo.

Apesar de sua importância nas florestas tropicais, usualmente, lianas são coletadas de forma oportuna, não sendo abordadas como o principal objetivo dos estudos botânicos (Gentry, 1991; Morellato, 1991). No Brasil, os poucos trabalhos que dão um maior enfoque às lianas foram realizados na vegetação amazônica (Gentry, 1991) e, mais recentemente, em florestas semideciduais (Morellato, 1991; Bernacci \& Leitão Filho, 1996; Morellato \& Leitão Filho, 1996 e 1998; Rezende, 1997; Hora, 1999; Lombardi \& Gonçalves, 2000; Udulutsch, 2001) e atlântica (Lima et al., 1997; Kim, 1996). No entanto, a maioria desses trabalhos trata principalmente das relações ecológicas, fornecendo poucas ferramentas para o reconhecimento das espécies, como diagnoses, chaves e guias de identificação. 
Dada a importância do componente de lianas na estrutura e dinâmica de uma floresta, torna-se imprescindível o conhecimento desses táxons, não só para o entendimento dessas formações florestais, mas também como base para posteriores estudos sobre a ecologia das mesmas e até de seus manejos, sendo este último enfoque de grande importância em locais perturbados. Com base no que já foi exposto, enfatizando a importância desta forma de vida e sabendo que poucos são os trabalhos no Brasil que abordam as lianas, esta comunidade terá suas espécies tratadas neste estudo.

\subsection{Objetivos}

Tendo em vista a necessidade de se estudar as formações vegetais do Estado de São Paulo de forma mais detalhada, a fim de que sua composição florística seja definida e seu processo de dinâmica compreendido, o presente trabalho apresenta os seguintes objetivos:

\section{Objetivos gerais:}

1 Contribuir para o conhecimento da flora do Parque Estadual Carlos Botelho (P.E.C.B.) e da Estação Ecológica dos Caetetus (E.E.C.), através do levantamento florístico da comunidade de lianas lenhosas;

2 Fornecer instrumentos de fácil e prática consulta que auxiliem na identificação das lianas dos locais acima citados;

3 Contribuir para o projeto temático vinculado ao BIOTA/FAPESP, "Diversidade, dinâmica e conservação em Florestas do Estado de São Paulo: 40ha de parcelas permanentes", pois auxiliará no reconhecimento das espécies de lianas lenhosas quando as parcelas forem reavaliadas, além de estar contribuindo com o levantamento de mais uma forma de vida, 
possibilitanto que os estudos de diversidade, dinâmica e conservação possam ser mais completos.

Objetivos específicos:

1 Identificar e elaborar uma diagnose para cada espécie de liana lenhosa amostrada nas sub-parcelas dos trechos de Floresta Ombrófila Densa (P.E.C.B.) e Floresta Estacional Semidecidual (E.E.C.);

2 Produzir chaves de identificação para as lianas lenhosas dessas sub-parcelas com base apenas em caracteres vegetativos;

3 Ilustrar através de registros fotográficos características fundamentais para a identificação das espécies, como detalhes do caule, folhas e estruturas reprodutivas quando presentes.

4 Com base nas diagnoses, chaves de identificação e registros fotográficos, elaborar um guia ilustrado de identificação para as lianas lenhosas das subparcelas estudadas na E.E.C. e P.E.C.B. 


\section{METODOLOGIA}

\section{1 Áreas de Estudo}

Para a realização deste trabalho foram incluídas duas áreas florestais do Estado de São Paulo, abordadas pelo projeto temático "Diversidade, dinâmica e conservação em florestas do Estado de São Paulo: 40ha de parcelas permanentes" (Anexo A). O projeto "Parcelas Permanentes" está sendo desenvolvido nas quatro principais formações florestais do Estado, mas para o presente estudo optou-se em considerar apenas duas: floresta atlântica e floresta estacional semidecidual.

\subsubsection{Estação Ecológica dos Caetetus}

A Estação Ecológica dos Caetetus (E.E.C.) possui uma área contínua de 2.178,84 ha situada nos municípios de Gália e Alvinlândia, Estado de São Paulo, entre as coordenadas geográficas: $2^{\circ} 41^{\prime}$ e $22^{\circ} 46^{\prime} \mathrm{S}$ e $49^{\circ} 10^{\prime}$ e $49^{\circ} 16^{\prime} \mathrm{W}$ (Figura 1), e está incluída na bacia hidrográfica do Médio Paranapanema.

Predominam nas áreas mais elevadas da E.E.C. (altitude média de $650 \mathrm{~m}$ ) o Latossolo de textura média Álico, enquanto nas partes mais baixas (altitude média de 550m) o Podzólico Vermelho-Amarelo Profundo de textura arenosa/média (Mattos et al., 1996). O clima local, segundo a proposta de classificação de Köeppen (1948), é Cwa, mesotérmico de inverno seco.

A E.E.C. caracteriza-se como um grande remanescente de Floresta Estacional Semidecidual de acordo com a classificação de Veloso \& Góes-Filho 
(1982), do Planalto Ocidental do Estado de São Paulo. Essa formação florestal revestia originalmente parte do Planalto Paulista, a Depressão Periférica, a Cuesta Basáltica e parte do Planalto Ocidental do interior paulista, certamente constituindo-se hoje na formação florestal mais ameaçada do Estado, face à sua fragmentação como conseqüência de alterações antrópicas, já que quase toda sua ocupação original é agriculturável (Mattos et al., 1996).

\subsubsection{Parque Estadual Carlos Botelho}

O Parque Estadual Carlos Botelho (P.E.C.B.) possui área total de $37.793,63$ ha e encontra-se na região sul do Estado de São Paulo $\left(24^{\circ} 00^{\prime}\right.$ a $24^{\circ} 15^{\prime}$ 'S, $47^{\circ} 45^{\prime}$ a $48^{\circ} 10^{\prime} \mathrm{W}$ ) (Figura 1). Engloba parte dos municípios de São Miguel Arcanjo, Capão Bonito e Sete Barras, com altitudes que variam de 30 a $1000 \mathrm{~m}$ (Domingues \& Silva, 1988). De acordo com a classificação de Veloso \& GóesFilho (1982), trata-se de uma região de Floresta Ombrófila Densa Submontana/Montana.

O P.E.C.B. compreende duas unidades geomorfológicas: o Planalto de Guapiara, drenado pelos rios que formam a bacia hidrográfica do rio Parapanema e a Serra de Paranapiacaba, drenada pelos ribeirões Travessão, Temível e da Serra e pelos rios Preto e Quilombo, todos formadores da bacia do rio Ribeira de Iguape. Predominam no Parque as rochas graníticas, que definem um relevo altamente acidentado (Domingues \& Silva, 1988). Esse relevo define dois tipos climáticos diferentes, segundo a classificação de Köeppen (1948): a) clima quente úmido sem estiagem ( $\mathrm{Cfa}$ ), que ocupa áreas do Planalto de Guapiara com altitudes inferiores a $800 \mathrm{~m}$ e a média e a baixa escarpa da Serra de Paranapiacaba, possuindo temperaturas inferiores a $18^{\circ} \mathrm{C}$ no mês mais frio e superiores a $22^{\circ} \mathrm{C}$ no mês mais quente, sendo o total pluviométrico do mês mais seco superior a $30 \mathrm{~mm}$; b) clima temperado úmido sem estiagem ( $\mathrm{Cfb}$ ), nas partes mais elevadas da Serra de Paranapiacaba e que difere do anterior apenas 
pela temperatura média do mês mais quente, a qual não ultrapassa $22^{\circ} \mathrm{C}$ (Setzer, 1946).

No P.E.C.B. foram descritas a ocorrência de solos Hidromórficos e Podzólicos Vermelho-Amarelo "intergrade" Latossolo Vermelho-Amarelo (Camargo et al., 1987). Os solos do Parque apresentam elevados teores de matéria orgânica e de alumínio, baixos teores de bases trocáveis e ainda acidez elevada, como a maioria dos solos da região serrana do litoral do Estado (Negreiros, 1982).

\subsection{Amostragem}

Foi alocada, em cada uma das áreas de estudo, uma parcela de 10,4 ha, sub-dividida em 256 sub-parcelas de $20 \times 20 \mathrm{~m}$. Para o presente estudo, foram sorteadas 50 sub-parcelas (Figura 2) em cada área, perfazendo um total de 2 ha. Foi utilizado o mesmo sorteio para as duas formações florestais onde o levantamento florístico das lianas lenhosas foi realizado. O método de sorteio para as sub-parcelas foi empregado com a finalidade de obter uma amostragem aleatória, percorrendo áreas não contínuas.

Na E.E.C., o marco A0 da parcela permanente (Figura 2) apresenta as seguintes coordenadas (UTM/SAD69): x=633687,344 e y=7521076,166. Quanto à vegetação da parcela (Figura 3), o estrato arbóreo atinge em média 20-25m de altura, sendo composto principalmente por representantes das famílias Leguminosae, Meliaceae, Euphorbiaceae, Myrtaceae e Lauraceae, e sub-bosque muito bem representado por indivíduos de Metrodorea nigra A. St. Hil. (Rutaceae). As epífitas são pouco freqüentes, com predomínio de espécies pertencentes às famílias Polypodiaceae, Orchidaceae e Cactaceae. Em contrapartida, as lianas apresentam papel determinante na fisionomia dessa formação florestal, constituindo densos emaranhados que dificultam até mesmo a locomoção 

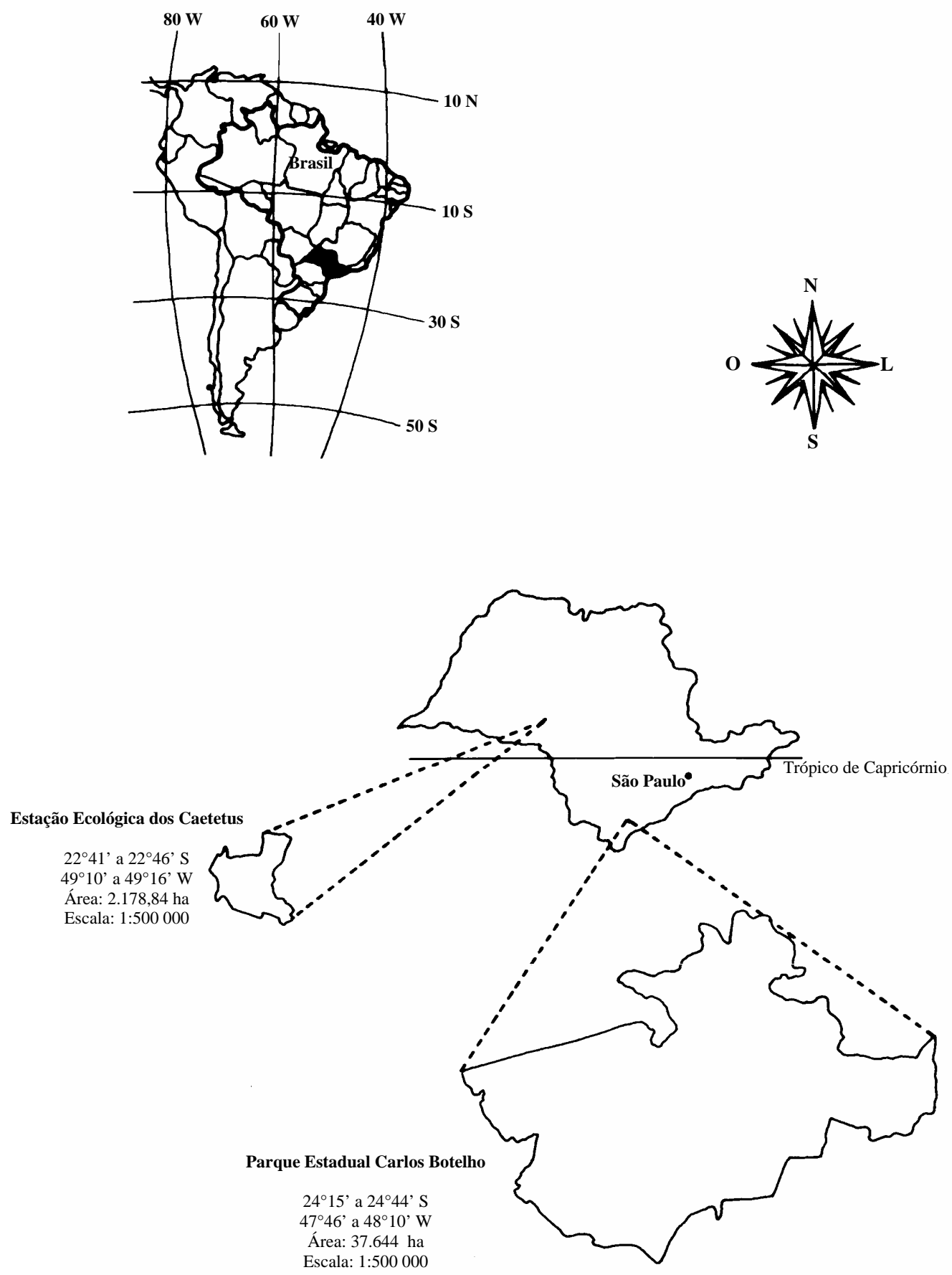

Figura 1 - Mapa de localização das duas áreas de estudo no Estado de São Paulo 
na área. (Corrêa et al.). ${ }^{3}$

A parcela permanente do P.E.C.B possui o marco A0 nas seguintes coordenadas (em UTM/SAD69): $x=202480,82$ e $y=7222544,01$. Com relação à vegetação (Figura 4), o estrato arbóreo pode atingir $30 \mathrm{~m}$ ou mais de altura, sendo principalmente composto por representantes das famílias Myrtaceae, Leguminosae, Rubiaceae, Lauraceae e Sapotaceae, e sub-bosque ricamente representado por fetos arborescentes (Cyatheaceae), palmito (Euterpe edulis Mart. -Arecaceae) e uma espécie de Nyctaginaceae (Guapira opposita Vell.), a qual geralmente está associada aos cursos d’água. As epífitas apresentam papel marcante na fisionomia de tal formação vegetal, sendo a área densamente ocupada por membros das famílias Orchidaceae, Bromeliaceae, Araceae, Hymenophyllaceae e Polypodiaceae. As lianas nessa fisionomia ocorrem de forma esparsa, diferentemente do que foi encontrado na E.E.C., com formação de pequenos agrupamentos de indivíduos da mesma espécie. $\mathrm{O}$ estrato herbáceo é dominado por Calathea communis Wanderley \& S. Vieira (Marantaceae) (Souza et al.). ${ }^{4}$

Foram coletadas todas as lianas lenhosas ocorrentes nas sub-parcelas sorteadas, sendo consideradas como integrantes de uma parcela aquelas que possuíam ao menos ramos com folhas nesta, independentemente da base estar ou não ligada ao solo dentro da área delimitada. Além das sub-parcelas, também foram coletadas as lianas lenhosas encontradas ao longo das trilhas de acesso à parcela permanente e na borda e trilhas dos remanescentes florestais, em áreas próximas às instalações do Instituto Florestal. As coletas foram feitas com o mínimo impacto possível, utilizando uma tesoura de poda alta e, na maioria das vezes, técnica de escalada.

3 CORRÊA, G.A.D.; RIBEIRO, R.R. \& SOUZA, V.C. Comunicação pessoal, 2003. Dados preliminares do projeto "Parcelas Permanentes".

4 SOUZA, V.C.; RIBEIRO, R.R.; DUARTE, A.R. Comunicação pessoal, 2003. Corresponde aos dados preliminares do projeto "Parcelas Permanentes". 
Para o P.E.C.B., a área considerada para que pudessem ser feitas as comparações com outros estudos incluiu apenas a região aos arredores onde a amostragem foi realizada (cerca de 1000 ha) e não a área total do Parque, pois este é muito grande e abrange áreas muito distintas do ponto de vista florístico.

Sabendo da problemática envolvida na definição de liana, uma vez que não há consenso por parte dos mais diversos autores até o momento, optou-se por buscar definições (adaptadas de Veloso (1992) e Putz \& Windsor (1987)), as quais serão empregadas no presente trabalho. Definiu-se lianas como sendo plantas lenhosas ou herbáceas que utilizam um forófito como suporte durante a maior parte de seu desenvolvimento (com exceção apenas dos estágios iniciais, onde há um período considerado crucial para a continuidade de seu desenvolvimento, a procura pelo forófito) e que mantém um contato permanente com o solo. Esse contato, se perdido, pode comprometer a sobrevivência do indivíduo ou, em poucos casos, levar à formação de raízes adventícias que crescem em direção ao solo (são as chamadas raízes alimentadoras). Segundo as adaptações que apresentam e que permitem a relação com o forófito seguiu-se a classificação abaixo:

- Lianas preênseis: possuem estruturas preensoras, como gavinhas (órgãos de fixação, em geral filiformes, que envolvem o forófito helicoidalmente) ou ganchos (porções sensitivas do caule que podem enroscar-se como se fossem gavinhas, mas não são filiformes);

- Lianas volúveis: possuem caules ou ramos que envolvem o forófito de forma helicoidal.

- Lianas escandentes: possuem em geral ramos longos, geralmente divaricados (perpendiculares ao caule principal), que se apóiam em outras plantas; muitas vezes as espécies incluídas nessa categoria apresentam estruturas especializadas que auxiliam no apoio ao forófito, como os espinhos; 
Também é citada como adaptação a presença de raízes adventícias ao longo do caule (raízes grampiformes), o que caracteriza as chamadas radicantes. Essa categoria não está sendo considerada no presente trabalho por ser uma particularidade das hemiepífitas. Quando as raízes adventícias ocorrem nas lianas, apenas crescem em direção ao solo (raízes alimentadoras), sem contribuir para a fixação no forófito.

Tanto as lianas como as hemiepífitas apresentam um crescimento rápido em altura em comparação do investimento em sua sustentação. Por esse motivo, muitas hemiepífitas são confundidas com lianas, mas, diferentemente apresentam raízes adventícias ao longo do caule, as quais são altamente responsáveis pelo sucesso de sua sustentação. Por definição, hemiepífitas são plantas que utilizam um forófito como apoio e que não apresentam contato com o solo em uma das fases do seu desenvolvimento: podem germinar no solo e futuramente perder o contato com o mesmo (hemiepífitas secundárias) ou germinar em um forófito e, então, enviar raízes para o solo (Benzing, 1990), além de produzir raízes que auxiliam na fixação da planta ao forófito (hemiepífitas primárias). Trata-se de uma definição que não é muito prática quando não se conhece a espécie, pois, no campo, os indivíduos podem ser encontrados mantendo contato com o solo e a certeza da classificação advém de um acompanhamento de longo prazo. Embora as definições de liana e hemiepífita, em uma primeira vista, pareçam se sobrepor, se forem analisadas com cautela, apresentam uma diferença fundamental para o reconhecimento prático da forma de vida: a função das raízes adventícias, uma vez que toda hemiepífita apresenta as raízes grampiformes. Mas, a título de definição, o principal fator que separa liana de hemiepífita é a questão de sobrevivência do indivíduo, uma vez que as lianas obrigatoriamente necessitam do solo para o seu desenvolvimento e quando ocorre a perda permanente desse contato, há a morte do indivíduo. 
Para cada planta coletada foi anotado o número da árvore onde a liana estava apoiada (todas as árvores com $\mathrm{PAP} \geq 15 \mathrm{~cm}$ foram marcadas e numeradas - trabalho realizado por uma equipe do Projeto "Parcelas Permanentes"), para facilitar a procura do indivíduo caso fosse necessário recoletá-lo. Também foram feitos registros fotográficos em campo, quando possível, ou, em último caso, os registros foram feitos do material já herborizado. Para algumas fografias de frutos e sementes foi utilizada uma escala quadriculada, na qual cada unidade apresenta $1 \mathrm{~cm}$ de lado.

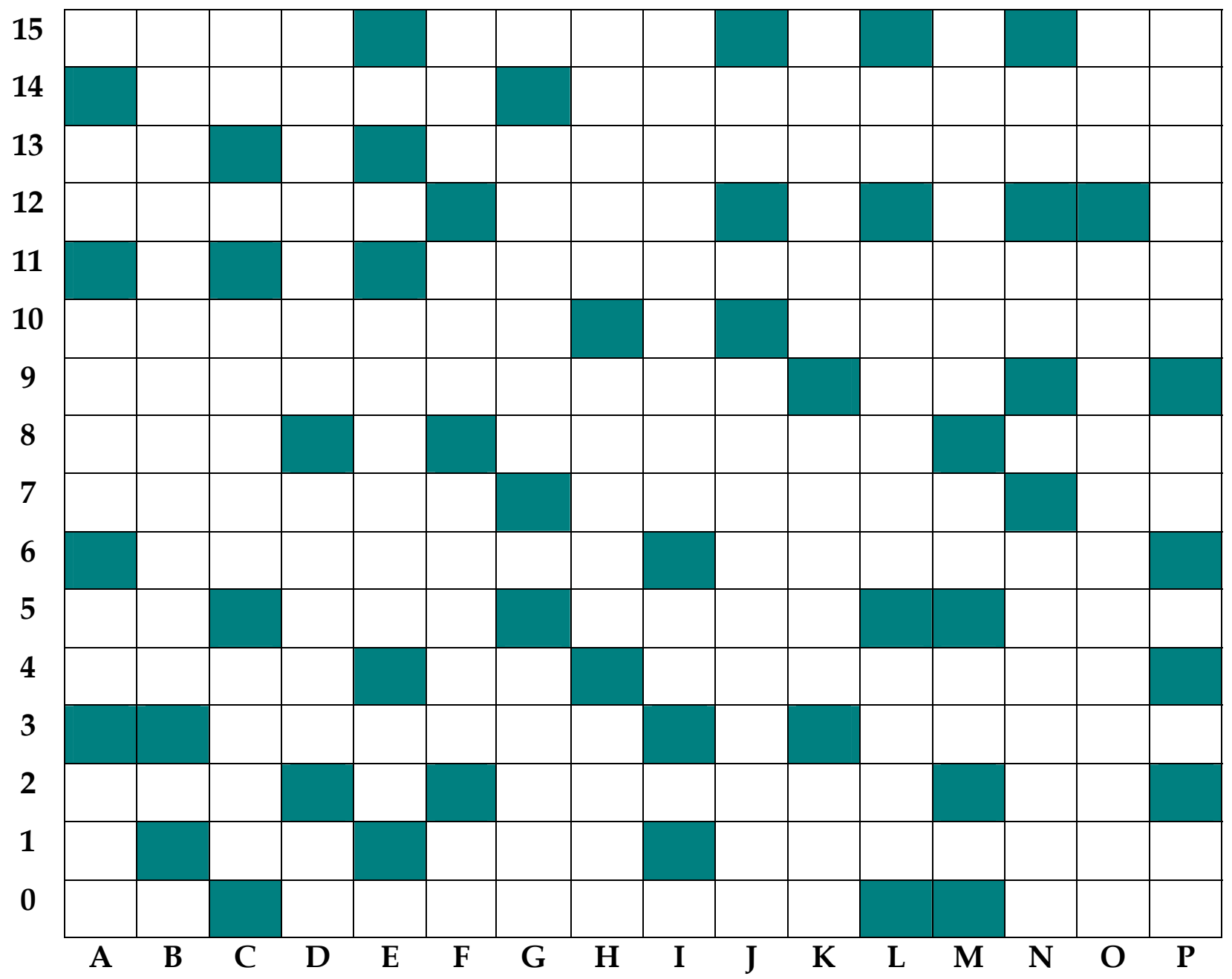

Figura 2 - Sub-parcelas sorteadas para a realização do levantamento florístico das lianas lenhosas 
O material coletado foi preparado e herborizado e as exsicatas depositadas no Herbário ESA, pertencente à ESALQ/USP. Concomitantemente, foram feitas as identificações utilizando bibliografia especializada e, quando necessário, comparando com exsicatas disponíveis nos herbários ESA, HRCB, SP, SPF e UEC. Para os táxons com elevada complexidade taxonômica foram consultados os seguintes especialistas: Dra. Luiza S. Kinoshita (Apocynaceae), Dr. Lindolpho Capellari Júnior (Aristolochiaceae), Dr. Marco Antonio de Assis (Bignoniaceae), Dr. Julio Lombardi (Hippocrateaceae e Vitaceae), Dra. Maria Candida Henrique Mamede (Malpighiaceae), Dra. María Silvia Ferrucci (Sapindaceae) e Dr. João Renato Stehmann (Solanaceae).

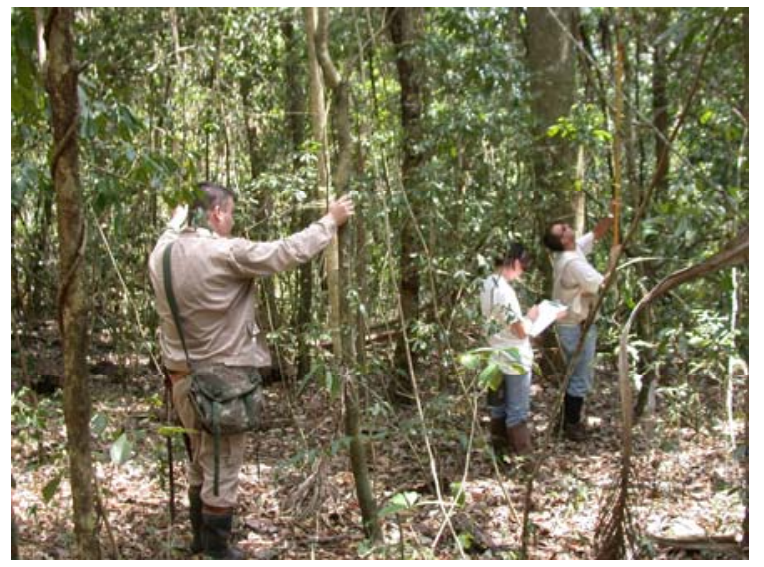

Figura 3 - Aspecto geral da vegetação na Estação Ecológica dos Caetetus 


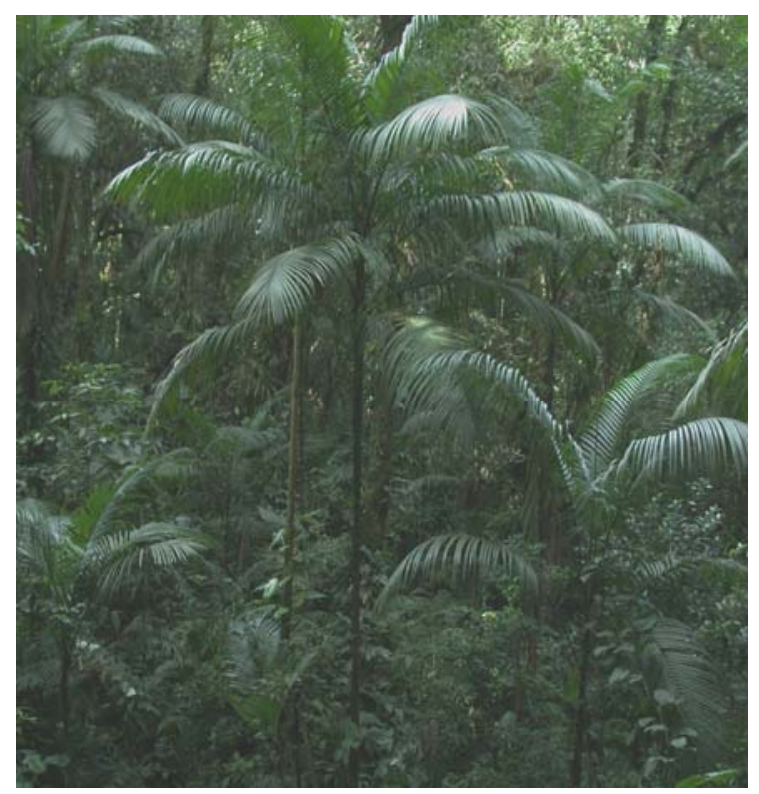

Figura 4 - Aspecto geral da vegetação no Parque Estadual Carlos Botelho

\subsection{Produção do guia ilustrado de identificação}

Para cada espécie coletada e devidamente identificada, foi elaborada uma breve diagnose, intitulada "Dica de Campo", com ênfase em características de maior importância para o seu reconhecimento prático. Também foram feitas chaves dicotômicas de identificação, baseadas exclusivamente em características vegetativas. Foi elaborada uma chave para as famílias de lianas lenhosas (cujos terminais são famílias) e uma chave para as espécies de cada família. Também foram feitos alguns comentários, incluindo distribuição e características morfológicas para as famílias, com base nas referências listadas no item “Bibliografia recomendada".

Partindo destas informações e dos registros fotográficos foram elaborados os guias ilustrados de identificação para as lianas lenhosas amostradas nas subparcelas das formações florestais estudadas (Floresta Estacional Semidecídua e 
Floresta Ombrófila Densa Sub-montana) (Anexos B e C), tendo como modelo a “Flora da Reserva Ducke" (Ribeiro et al., 1999). 


\section{RESULTADOS E DISCUSSÃO}

\subsection{Composição florística}

O levantamento florístico realizado na Estação Ecológica dos Caetetus (E.E.C.) catalogou 76 espécies de lianas lenhosas, distribuídas por 52 gêneros e 19 famílias (Tabela 1). As famílias com maior riqueza de espécies foram Bignoniaceae, com 26 espécies, o que representa 34\% do total amostrado, seguida por Sapindaceae, com 11 (14\%), Apocynaceae e Malpighiaceae, com 7 cada (9\%) e Leguminosae, 6 (8\%) (Figura 5). Essas famílias com maior riqueza abrangem $74 \%$ das espécies, evidenciando que poucas são aquelas com um maior número de táxons, corroborando os dados citados nos estudos realizados em florestas estacionais semidecíduas do Estado de São Paulo (Rezende, 1997; Morellato \& Leitão Filho, 1998; Hora, 1999 e Udulutsch, 2001), que incluíram estas famílias entre aquelas com maior riqueza de espécies de lianas. Considerando apenas as coletas aleatórias, que foram realizadas ao longo de trilhas e na borda do fragmento estudado, foram levantadas 58 espécies e 16 famílias. Enquanto que nas sub-parcelas foram encontradas 51 espécies estando estas distribuídas por 15 famílias. 
Tabela 1. Listagem das espécies de lianas lenhosas ocorrentes na área amostrada da Estação Ecológica dos Caetetus (No. do COLETOR = R.G. Udulutsch)

\begin{tabular}{|c|c|c|c|}
\hline \multirow[b]{2}{*}{ FAMÍLIA } & \multirow[t]{2}{*}{ ESPÉCIE } & \multicolumn{2}{|c|}{$\begin{array}{c}\text { OCORRÊNCIA / No. do } \\
\text { COLETOR }\end{array}$} \\
\hline & & Sub-parcelas & $\begin{array}{c}\text { Fora das } \\
\text { sub- } \\
\text { parcelas }\end{array}$ \\
\hline AMARANTHACEAE & Hebanthe paniculata Mart. & 1628 & 2390 \\
\hline \multirow[t]{7}{*}{ APOCYNACEAE } & Condylocarpon isthmicum (Vell.) A. DC. & 1462 & 498 \\
\hline & Forsteronia australis Müll. Arg. & 1611 & \\
\hline & Forsteronia pilosa (Vell.) Müll. Arg. & 537 & 549 \\
\hline & Forsteronia pubescens DC. & 1599 & \\
\hline & Prestonia coalita (Vell.) Woodson & 1590 & 497 \\
\hline & Prestonia tomentosa R. Br. & & 538 \\
\hline & Temnadenia violacea (Vell.) Miers & 1464 & 1466 \\
\hline \multirow[t]{26}{*}{ BIGNONIACEAE } & Adenocalymma bracteatum (Cham.) DC. & & 1206 \\
\hline & Adenocalymma marginatum (Cham.) DC. & 1617 & 528 \\
\hline & Adenocalymma paulistarum Bureau \& K. Schum. & 1476 & 1207 \\
\hline & Amphilophium paniculatum (L.) Kunth & 1485 & 548 \\
\hline & Anemopaegma chamberlaynii (Sims) Bureau \& K. Schum. & 1605 & 1196 \\
\hline & Arrabidaea brachypoda (A. DC.) Bureau & & 842 \\
\hline & Arrabidaea chica (Humb. \& Bonpl.) B. Verl. & & 1205 \\
\hline & Arrabidaea conjugata (Vell.) Mart. & 516 & 2375 \\
\hline & Arrabidaea florida A. DC. & 510 & 545 \\
\hline & Arrabidaea pulchella Bureau & & 1204 \\
\hline & Arrabidaea pulchra (Cham.) Sandwith & 1469 & 2376 \\
\hline & Arrabidaea samydoides (Cham.) Sandwith & & 495 \\
\hline & Arrabidaea triplinervia (Mart. ex DC.) Baill. ex Bureau & & 503 \\
\hline & Clytostoma sciuripabulum Bureau \& K. Schum. & 1608 & 1644 \\
\hline & Cuspidaria convoluta (Vell.) A.H. Gentry & & 543 \\
\hline & Distictella elongata (Vahl) Urb. & & 1210 \\
\hline & Fridericia speciosa Mart. & & 1209 \\
\hline & Glaziovia bauhinioides Bureau ex Baill. & 1483 & \\
\hline & Lundia obliqua Sonder & 1610 & 493 \\
\hline & Macfadyena mollis (Sond.) Seem. & 1478 & \\
\hline & Macfadyena unguis-cati (L.) A.H. Gentry & 1471 & 490 \\
\hline & Mansoa difficilis (Cham.) Bureau \& K. Schum. & 508 & 519 \\
\hline & Pithecostenium crucigerum (L.) A.H. Gentry & 1475 & \\
\hline & Pyrostegia venusta (Ker Gawl.) Miers & 1477 & 1007 \\
\hline & Stizophyllum perforatum (Cham.) Miers & 1470 & 1194 \\
\hline & Tynanthus micranthus Corr. Méllo ex K. Shum. & 1619 & \\
\hline CACTACEAE & Pereskia aculeata Mill. & 507 & 518 \\
\hline \multirow[t]{3}{*}{ DILLENIACEAE } & Davilla rugosa Poir. & 1486 & 1581 \\
\hline & Doliocarpus dentatus (Aubl.) Standl. & & 520 \\
\hline & Doliocarpus sp. & 1606 & \\
\hline
\end{tabular}


Tabela 1. Listagem das espécies de lianas lenhosas ocorrentes na área amostrada da Estação Ecológica dos Caetetus (No. do COLETOR ${ }^{*}=$ R.G. Udulutsch)

\begin{tabular}{|c|c|c|c|}
\hline \multirow[b]{2}{*}{ FAMÍLIA } & \multirow[t]{2}{*}{ ESPÉCIE } & \multicolumn{2}{|c|}{$\begin{array}{c}\text { OCORRÊNCIA / No. do } \\
\text { COLETOR }\end{array}$} \\
\hline & & Sub-parcelas & $\begin{array}{c}\text { Fora das } \\
\text { sub- } \\
\text { parcelas }\end{array}$ \\
\hline \multirow{2}{*}{ HIPPOCRATEACEAE } & Anthodon decussatum Ruiz \& Pav. & 1623 & \\
\hline & Hippocratea volubilis $\mathrm{L}$. & 1487 & \\
\hline LEG. - Caesalpinioideae & Bauhinia microstachya (Raddi) J.F. Macbr. & 1489 & \\
\hline \multirow[t]{2}{*}{ LEG. - Faboideae } & Dalbergia frutescens (Vell.) Britton & 1616 & 502 \\
\hline & Dioclea cf. virgata (Rich.) Amshoff & & 531 \\
\hline \multirow[t]{3}{*}{ LEG. - Mimosoideae } & Acacia mollissima Willd. & & 500 \\
\hline & Acacia plumosa Lowe & 1490 & 869 \\
\hline & Acacia polyphylla DC. & & 820 \\
\hline \multirow[t]{7}{*}{ MALPIGHIACEAE } & Banisteriopsis muricata (Cav.) Cuatrec. & 511 & 527 \\
\hline & Banisteriopsis oxyclada (A. Juss.) B. Gates & & 494 \\
\hline & Dicella bracteosa (A. Juss.) Griseb. & 512 & 526 \\
\hline & Heteropterys sp. & 1632 & \\
\hline & Mascagnia cordifolia (A. Juss.) Griseb. & 1491 & \\
\hline & Tetrapterys multiglandulosa A. Juss. & & 499 \\
\hline & Tetrapterys phlomoides (Sprengel) Nied. & & 501 \\
\hline MENDONCIACEAE & Mendoncia velloziana Mart. & & 1658 \\
\hline \multirow[t]{2}{*}{ NYCTAGINACEAE } & Bougainvillea glabra Choisy & 506 & \\
\hline & Pisonia aculeata $\mathrm{L}$. & 1496 & 2380 \\
\hline PHYTOLACCACEAE & Seguieria floribunda Benth. & 1495 & \\
\hline RHAMNACEAE & Gouania acalyphoides Reissek & 536 & 542 \\
\hline \multirow[t]{11}{*}{ SAPINDACEAE } & Cardiospermum grandiflorum Sw. & & 831 \\
\hline & Paullinia rhomboidea Radlk. & & 1652 \\
\hline & Serjania caracasana (Jacq.) Willd. & 1502 & 1008 \\
\hline & Serjania fuscifolia Radlk. & 1505 & 2392 \\
\hline & Serjania glabrata Kunth & 2549 & \\
\hline & Serjania laruotteana Cambess. & 1618 & 2487 \\
\hline & Serjania meridionalis Cambess. & 1643 & 525 \\
\hline & Serjania multiflora Cambess. & & 2391 \\
\hline & Serjania pinnatifolia Radlk. & & 2393 \\
\hline & Thinouia ventricosa Radlk. & 1597 & \\
\hline & Urvillea laevis Radlk. & 1638 & \\
\hline \multirow[t]{2}{*}{ SOLANACEAE } & Lycianthes australe (Morton) A.T. Hunz. \& Barboza & 1498 & 513 \\
\hline & Solanum hirtellum (Spreng.) Hassl. & 556 & 1593 \\
\hline STERCULIACEAE & Byttneria catalpifolia Jacq. & 1635 & 1655 \\
\hline TRIGONIACEAE & Trigonia nivea Cambess. & & 547 \\
\hline ULMACEAE & Celtis iguanae (Jacq.) Sarg. & & 1592 \\
\hline VERBENACEAE & Petrea volubilis $\mathrm{L}$. & & 2381 \\
\hline VITACEAE & Cissus verticillata (L.) Nicolson \& C.E. Jarvis & 1497 & \\
\hline
\end{tabular}




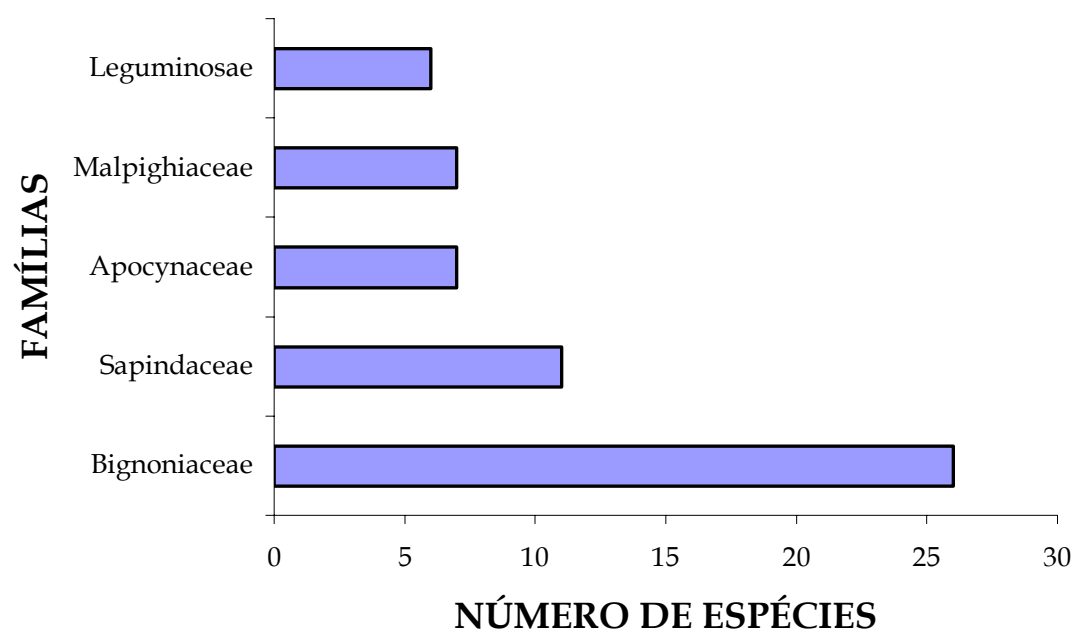

Figura 5 - Famílias mais representativas segundo o número de espécies de lianas lenhosas ocorrentes na área amostrada da Estação Ecológica dos Caetetus

Na área de Mata Atlântica amostrada no Parque Estadual Carlos Botelho, foram levantadas 19 famílias, 40 gêneros e 49 espécies (Tabela 2). As famílias com maior número de representantes (Figura 6) foram Leguminosae, com 8 espécies, representando $16 \%$ do total amostrado, Apocynaceae e Hippocrateaceae, com 6 espécies cada (12\%) e Bignoniaceae e Malpighiaceae, com 5 cada (10\%). Essas famílias contribuem com $60 \%$ do total amostrado e estão corroborando os resultados obtidos nos trabalhos desenvolvidos em mata atlântica no Estado de São Paulo (Kim, 1996; Lima et al., 1997), principalmente se forem desconsideradas as lianas herbáceas, as quais foram incluídas nos dois levantamentos citados para o Estado. Levando em consideração apenas as coletas realizadas ao longo das trilhas e bordas de mata, foram catalogadas 31 espécies, distribuídas por 12 famílias. Enquanto que nas sub-parcelas amostradas foram levantadas 37 espécies e 16 famílias. 
Tabela 2. Listagem das espécies de lianas lenhosas ocorrentes na área amostrada do Parque Estadual Carlos Botelho (No. do COLETOR = R.G. Udulutsch)

\begin{tabular}{|c|c|c|c|}
\hline \multirow[b]{2}{*}{ FAMÍLIA } & \multirow[b]{2}{*}{ ESPÉCIE } & \multicolumn{2}{|c|}{$\begin{array}{c}\text { OCORRÊNCIA / No. do } \\
\text { COLETOR }\end{array}$} \\
\hline & & $\begin{array}{c}\text { Sub- } \\
\text { parcelas }\end{array}$ & $\begin{array}{l}\text { Fora das } \\
\text { sub- } \\
\text { parcelas }\end{array}$ \\
\hline \multirow[t]{6}{*}{ APOCYNACEAE } & Forsteronia sp. & 1362 & 2430 \\
\hline & Mandevilla funiformis (Vell.) K. Schum. & & 1305 \\
\hline & Mandevilla urophylla (Hook.) Woodson & & 1333 \\
\hline & Peltastes peltatus (Vell.) Woodson & 1328 & 609 \\
\hline & Prestonia coalita (Vell.) Woodson & 2451 & \\
\hline & Secondatia densiflora A. DC. & 2343 & \\
\hline ARISTOLOCHIACEAE & Aristolochia paulistana Hoehne & 2452 & 2429 \\
\hline ASTERACEAE & Mikania hirsutissima DC. & 1363 & \\
\hline \multirow[t]{5}{*}{ BIGNONIACEAE } & Adenocalymma grandifolium Mart. ex DC. & & 1357 \\
\hline & $\begin{array}{l}\text { Adenocalymma ternatum (Vell.) Corr. Méllo ex } \\
\text { Bureau \& K. Schum. }\end{array}$ & 1364 & 1341 \\
\hline & $\begin{array}{l}\text { Anemopaegma lanceolatum (A. DC.) Bureau ex K. } \\
\text { Schum. }\end{array}$ & 1330 & 688 \\
\hline & Parabignonia unguiculata (Vell.) A.H. Gentry & 1317 & 2442 \\
\hline & Paragonia pyramidata (Rich.) Bureau & 1308 & 1331 \\
\hline CACTACEAE & Pereskia aculeata Mill. & 1368 & \\
\hline CONNARACEAE & Connarus rostratus (Vell.) L.B. Sm. & 1311 & \\
\hline \multirow{2}{*}{ DILLENIACEAE } & Davilla sp. & & 1343 \\
\hline & Dolliocarpus dentatus (Aubl.) Standl. & & 2325 \\
\hline \multirow[t]{6}{*}{ HIPPOCRATEACEAE } & Anthodon decussatum Ruiz \& Pav. & 1315 & \\
\hline & Cheiloclinium cognatum (Miers) A.C. Sm. & & 1346 \\
\hline & Peritassa sp. & 2362 & \\
\hline & Salacia elliptica (Mart. ex Schult.) G. Don & 1310 & \\
\hline & Salacia mosenii A.C. Sm. & 2361 & \\
\hline & Tontelea sp. & 1374 & \\
\hline \multirow[t]{2}{*}{ LEG. - Caesalpinioideae } & Bauhinia guianensis Aubl. & & 684 \\
\hline & Bauhinia microstachya (Raddi) J.F. Macbr. & 1314 & 2446 \\
\hline \multirow[t]{5}{*}{ LEG. - Faboideae } & Dahlstedtia pentaphylla (Taub.) Burkart & 1337 & \\
\hline & Dahlstedtia pinnata (Benth.) Malme & & 1348 \\
\hline & Dalbergia frutescens (Vell.) Britton & 1307 & 1359 \\
\hline & Machaerium triste Vogel & 1379 & \\
\hline & Mucuna urens (L.) Medik. & 1384 & 1385 \\
\hline LEG. - Mimosoideae & Acacia lacerans Benth. & 2353 & 2447 \\
\hline LOGANIACEAE & Strychnos trinervis (Vell.) Mart. & 1386 & 1350 \\
\hline \multirow[t]{5}{*}{ MALPIGHIACEAE } & Banisteriopsis argyrophylla (A. Juss.) B. Gates & 1387 & \\
\hline & Heteropterys intermedia (Grisebach) A. Juss. & & 473 \\
\hline & Heteropterys nitida (Lamarck) DC. & 2470 & 2428 \\
\hline & Hiraea sp. 1 & 2471 & 2435 \\
\hline & Hiraea sp. 2 & 2333 & \\
\hline
\end{tabular}


Tabela 2. Listagem das espécies de lianas lenhosas ocorrentes na área amostrada do Parque Estadual Carlos Botelho (No. do COLETOR = R.G. Udulutsch)

\begin{tabular}{|c|c|c|c|}
\hline \multirow[b]{2}{*}{ FAMÍLIA } & \multirow[b]{2}{*}{ ESPÉCIE } & \multicolumn{2}{|c|}{$\begin{array}{c}\text { OCORRÊNCIA / No. do } \\
\text { COLETOR }\end{array}$} \\
\hline & & Sub-parcelas & $\begin{array}{l}\text { Fora das } \\
\text { sub- } \\
\text { parcelas }\end{array}$ \\
\hline MENDONCIACEAE & Mendoncia velloziana Mart. & & 1332 \\
\hline \multirow[t]{2}{*}{ MENISPERMACEAE } & Abuta selloana Eichler & 1324 & 1360 \\
\hline & Cissampelos andromorpha DC. & 2346 & 2432 \\
\hline PHYTOLACCACEAE & Seguieria floribunda Benth. & 2336 & \\
\hline POLYGONACEAE & Coccoloba cf. parimensis Benth. & 2472 & \\
\hline RUBIACEAE & Sabicea villosa Willd. ex Roem. \& Schult. & & 1334 \\
\hline \multirow[t]{4}{*}{ SAPINDACEAE } & Paullinia carpopoda Cambess. & 2335 & 1324 \\
\hline & Paullinia meliifolia Juss. & 1390 & 2433 \\
\hline & Paullinia trigonia Vell. & 1329 & 1351 \\
\hline & Serjania communis Cambess. & & 1329 \\
\hline VIOLACEAE & Anchietea pyrifolia (Mart.) G. Don. & 1393 & \\
\hline VITACEAE & Cissus verticillata (L.) Nicolson \& C.E. Jarvis & 2340 & \\
\hline
\end{tabular}

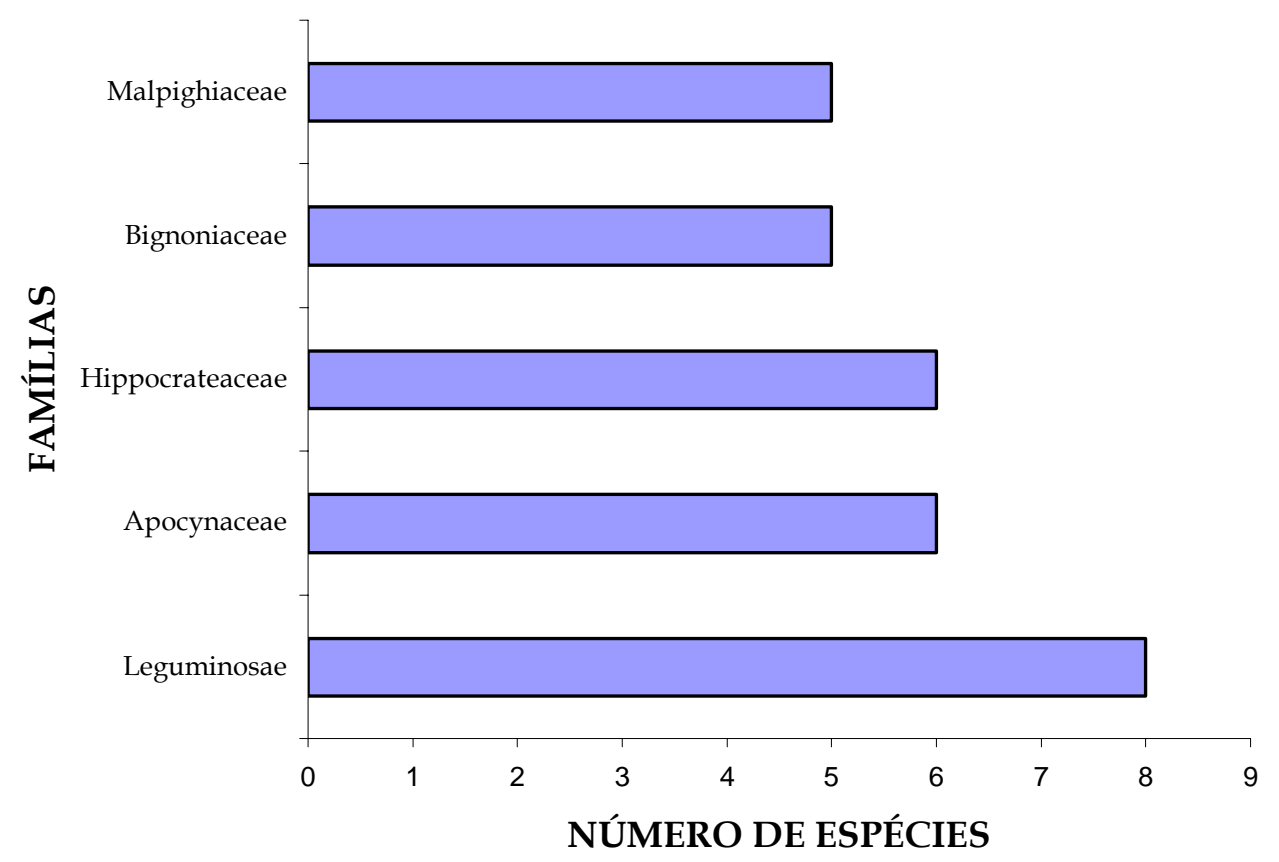

Figura 6 - Famílias mais representativas segundo o número de espécies de lianas lenhosas ocorrentes na área amostrada do Parque Estadual Carlos Botelho 
Para as duas áreas onde o estudo foi desenvolvido, as famílias com maior número de espécies, em geral, estão entre as 10 mais ricas em lianas do Novo Mundo listadas por Gentry (1991), embora a ordem de riqueza não seja exatamente a mesma: Leguminosae ocupa a $3^{a}$ posição, Bignoniaceae a 6a, Sapindaceae a 7a, Malpighiaceae a $8^{\mathrm{a}}$ e Apocynaceae a $10^{\mathrm{a}}$ posição. A única exceção é a família Hippocrateaceae, que para o P.E.C.B. está entre as mais representativas, mas ocupa a 25a posição na listagem de Gentry (1991). Uma observação que deve ser feita quando compara-se as famílias com maior riqueza amostradas no presente trabalho com a listagem para as famílias mais ricas em lianas do novo mundo, é que esta última listagem inclui lianas herbáceas e hemiepífitas, para exemplificar, os primeiro e segundo lugares são ocupados, respectivamente, por Asclepiadaceae e Convolvulaceae, duas famílias compostas quase que exclusivamente por lianas herbáceas, e o quinto lugar por Araceae, uma família com a maioria dos representantes hemiepífitas. Portanto, se fossem consideradas apenas as famílias representadas predominantemente por lianas lenhosas, Leguminosae, Asteraceae, Bignoniaceae, Sapindaceae, Malpighiaceae e Apocynaceae seriam as mais representativas, sendo esta a ordem de riqueza.

A contribuição significativa das lianas lenhosas para a flora das florestas estacionais semidecíduas e atlântica de encosta pode ser constatada através da comparação dos resultados obtidos nas duas áreas onde os levantamentos foram realizados com os dados de algumas regiões tropicais (Tabela 3). A riqueza de espécies tanto na E.E.C. quanto no P.E.C.B., ambos com área relativamente menor, pode ser considerada alta, com exceção apenas para a região de Palenque (Equador), onde em uma área de apenas 167 ha foram encontradas 171 espécies. 
Tabela 3. Número de espécies de lianas em florestas tropicais úmidas

\begin{tabular}{cccccc}
$\begin{array}{c}\text { E.E.C. } \\
(2.179 \text { ha })\end{array}$ & $\begin{array}{c}\text { P.E.C.B. } \\
(1.000 \text { ha })\end{array}$ & $\begin{array}{c}\text { M. Cima } \\
(7.200 \text { ha })\end{array}$ & $\begin{array}{c}\text { R. Ducke } \\
(10.000 \text { ha })\end{array}$ & $\begin{array}{c}\text { B. Colorado }^{3} \\
(15.600 \text { ha })\end{array}$ & $\begin{array}{c}\text { Palenque }^{4} \\
(167 \text { ha })\end{array}$ \\
\hline 76 & 49 & 714 & 266 & 171 \\
\hline \multicolumn{1}{l}{ Lima et al. (1997); ${ }^{2}$ Prance $(1994) ;{ }^{3}$ Croat $(1978) ;{ }^{4}$ Gentry \& Dodson $(1987)$}
\end{tabular}

Quando é feita uma comparação entre as espécies encontradas nas parcelas (interior de mata), com aquelas coletadas nas bordas e trilhas ao longo do remanescente florestal, verifica-se que da mesma forma que existem espécies em comum (que foram encontradas nas duas situações), existem aquelas que foram encontradas exclusivamente na borda.

Para a E.E.C., de um total de 76 espécies, 33 eram comuns para as duas situações, sendo que destas, cinco foram encontradas no interior da mata exclusivamente em regiões onde havia alta intensidade luminosa, ou seja, em regiões de clareiras, sendo elas Adenocalymma marginatum (Cham.) DC. e Arrabidaea conjugata (Vell.) Mart. (Bignoniaceae), Acacia plumosa Lowe (Leguminosae), Lycianthes australe (Morton) A.T. Hunz. \& Barboza e Solanum hirtellum (Spreng.) Hassl. (Solanaceae). Algumas espécies foram encontradas exclusivamente nas bordas do fragmento, sendo elas Prestonia tomentosa R. Br. (Apocynaceae), Arrabidaea triplinervia (Mart. ex DC.) Baill. ex Bureau (Bignoniaceae), Distictella elongata (Vahl) Urb. (Bignoniaceae), Doliocarpus dentatus (Aubl.) Standl. (Dilleniaceae), Tetrapterys phlomoides (Sprengel) Nied. (Malpighiaceae), Trigonia nivea Cambess. (Trigoniaceae) e Celtis iguanae (Jacq.) Sarg. (Ulmaceae). Já para o P.E.C.B., de um total de 49 espécies, apenas 17 foram comuns às duas situações, e destas, três foram encontradas exclusivamente nas clareiras, sendo elas Aristolochia paulistana Hoehne (Aristolochiaceae), Adenocalymma ternatum (Vell.) Corr. Méllo ex Bureau \& K. Schum. 
(Bignoniaceae) e Acacia lacerans Benth. (Leguminosae). Dentre as espécies que foram encontradas exclusivamente na borda, as mais comuns foram Mandevilla funiformis (Vell.) K. Schum. (Apocynaceae), Adenocalymma grandifolium Mart. ex DC. (Bignoniaceae) e Sabicea villosa Willd. ex Roem. \& Schltdl. (Rubiaceae).

Com o desenvolvimento do trabalho puderam ser identificadas as ocorrências de algumas espécies provavelmente novas para a ciência ou, caso contrário, novas para o Estado de São Paulo, sendo elas Forsteronia sp. (Apocynaceae) e duas espécies de Hiraea (Malpighiaceae), todas para o P.E.C.B.

Com o intuito de fornecer instrumentos que auxiliem na identificação das lianas lenhosas, foram elaborados guias ilustrados de identificação, um para cada área estudada, sendo o Anexo B referente às espécies amostradas na Estação Ecológica dos Caetetus e o Anexo C, às espécies do Parque Estadual Carlos Botelho. Como a idéia original do trabalho foi realizar apenas o levantamento florístico nas sub-parcelas, os guias de campo não incluem as espécies encontradas nas coletas aleatórias (trillhas e borda), mas apenas aquelas amostradas nas parcelas permanentes.

\subsection{Adaptações morfológicas desenvolvidas pelas lianas}

A fisionomia da vegetação na E.E.C. é fortemente marcada pela abundância tanto de indivíduos quanto de espécies com hábito lianescente. Já no P.E.C.B., essa forma de vida não se apresenta de forma tão marcante. As lianas, de um modo geral, são abundantes sobre a copa das árvores, tanto em

florestas primárias quanto em trechos em regeneração (Lima et al., 1997). As lianas lenhosas se caracterizam por habitar preferencialmente os ambientes florestais, atingindo grandes alturas na copa das árvores do dossel. Essa característica particular, que favoreceu o estabelecimento dessa forma de vida 
nas regiões tropicais, está entre as responsáveis pela significativa riqueza de espécies das florestas úmidas (Gentry \& Dodson, 1987). As novas bases da classificação das lianas têm sido desenvolvidas refletindo o recente aumento de interesse em seus aspectos ecológicos (Hegarty, 1991).

As lianas lenhosas amostradas nos locais estudados foram classificadas em três categorias: preênseis, volúveis e escandentes (Tabelas 4 e 5). A Tabela 6 mostra a quantificação desses tipos para a E.E.C. e para o P.E.C.B. 
Tabela 4. Listagem das espécies de lianas lenhosas amostradas na Estação Ecológica dos Caetetus e respectivas formas de escalada

\begin{tabular}{|c|c|c|}
\hline FAMÍLIA & ESPÉCIE & $\begin{array}{l}\text { FORMA DE } \\
\text { ESCALADA }\end{array}$ \\
\hline AMARANTHACEAE & Hebanthe paniculata Mart. & Volúvel \\
\hline \multirow{7}{*}{ APOCYNACEAE } & Condylocarpon isthmicum (Vell.) A. DC. & Volúvel \\
\hline & Forsteronia australis Müll. Arg. & Volúvel \\
\hline & Forsteronia pilosa (Vell.) Müll. Arg. & Volúvel \\
\hline & Forsteronia pubescens DC. & Volúvel \\
\hline & Prestonia coalita (Vell.) Woodson & Volúvel \\
\hline & Prestonia tomentosa R. Br. & Volúvel \\
\hline & Temnadenia violacea (Vell.) Miers & Volúvel \\
\hline \multirow[t]{26}{*}{ BIGNONIACEAE } & Adenocalymma bracteatum (Cham.) DC. & Preênsil \\
\hline & Adenocalymma marginatum (Cham.) DC. & Preênsil \\
\hline & Adenocalymma paulistarum Bureau \& K. Schum. & Preênsil \\
\hline & Amphilophium paniculatum (L.) Kunth & Preênsil \\
\hline & Anemopaegma chamberlaynii (Sims) Bureau \& K. Schum. & Preênsil \\
\hline & Arrabidaea brachypoda (A. DC.) Bureau & Preênsil \\
\hline & Arrabidaea chica (Humb. \& Bonpl.) B. Verl. & Preênsil \\
\hline & Arrabidaea conjugata (Vell.) Mart. & Preênsil \\
\hline & Arrabidaea florida A. DC. & Preênsil \\
\hline & Arrabidaea pulchella Bureau & Preênsil \\
\hline & Arrabidaea pulchra (Cham.) Sandwith & Preênsil \\
\hline & Arrabidaea samydoides (Cham.) Sandwith & Preênsil \\
\hline & Arrabidaea triplinervia (Mart. ex DC.) Baill. ex Bureau & Preênsil \\
\hline & Clytostoma sciuripabulum Bureau \& K. Schum. & Preênsil \\
\hline & Cuspidaria convoluta (Vell.) A.H. Gentry & Preênsil \\
\hline & Distictella elongata (Vahl) Urb. & Preênsil \\
\hline & Fridericia speciosa Mart. & Preênsil \\
\hline & Glaziovia bauhinioides Bureau ex Baill. & Preênsil \\
\hline & Lundia obliqua Sonder & Preênsil \\
\hline & Macfadyena mollis (Sond.) Seem. & Preênsil \\
\hline & Macfadyena unguis-cati (L.) A.H. Gentry & Preênsil \\
\hline & Mansoa difficilis (Cham.) Bureau \& K. Schum. & Preênsil \\
\hline & Pithecoctenium crucigerum (L.) A.H. Gentry & Preênsil \\
\hline & Pyrostegia venusta (Ker Gawl.) Miers & Preênsil \\
\hline & Stizophyllum perforatum (Cham.) Miers & Preênsil \\
\hline & Tynanthus micranthus Corr. Méllo ex K. Shum. & Preênsil \\
\hline CACTACEAE & Pereskia aculeata Mill. & Escandente \\
\hline \multirow[t]{2}{*}{ DILLENIACEAE } & Davilla rugosa Poir. & Volúvel \\
\hline & Doliocarpus dentatus (Aubl.) Standl. & Escandente \\
\hline DILLENIACEAE & Doliocarpus sp. & Volúvel \\
\hline \multirow[t]{2}{*}{ HIPPOCRATEACEAE } & Anthodon decussatum Ruiz \& Pav. & Preênsil \\
\hline & Hippocratea volubilis $\mathrm{L}$. & Preênsil \\
\hline LEG. - Caesalpinioideae & Bauhinia microstachya (Raddi) J.F. Macbr. & Preênsil \\
\hline \multirow{2}{*}{ LEG. - Faboideae } & Dalbergia frutescens (Vell.) Britton & Preênsil \\
\hline & Dioclea cf. virgata (Rich.) Amshoff & Volúvel \\
\hline \multirow[t]{3}{*}{ LEG. - Mimosoideae } & Acacia mollissima Willd. & Escandente \\
\hline & Acacia plumosa Lowe & Escandente \\
\hline & Acacia polyphylla DC. & Escandente \\
\hline MALPIGHIACEAE & Banisteriopsis muricata (Cav.) Cuatrec. & Volúvel \\
\hline
\end{tabular}


Tabela 4. Listagem das espécies de lianas lenhosas amostradas na Estação Ecológica dos Caetetus e respectivas formas de escalada

\begin{tabular}{llc}
\hline \multicolumn{1}{c}{ FAMÍLIA } & \multicolumn{1}{c}{ ESPÉCIE } & FORMA DE \\
& & ESCALADA \\
\hline MALPIGHIACEAE & Banisteriopsis oxyclada (A. Juss.) B. Gates & Volúvel \\
& Dicella bracteosa (A. Juss.) Griseb. & Volúvel \\
& Heteropterys sp. & Volúvel \\
& Mascagnia cordifolia (A. Juss.) Griseb. & Volúvel \\
& Tetrapterys multiglandulosa A. Juss. & Volúvel \\
& Tertrapterys phlomoides (Sprengel) Nied. & Volúvel \\
MENDONCIACEAE & Mendoncia velloziana Mart. & Volúvel \\
NYCTAGINACEAE & Bougainvillea glabra Choisy & Escandente \\
& Pisonia aculeata L. & Escandente \\
PHYTOLACCACEAE & Seguieria floribunda Benth. & Escandente \\
RHAMNACEAE & Gouania acalyphoides Reissek & Preênsil \\
SAPINDACEAE & Cardiospermum grandiflorum Sw. & Preênsil \\
& Paullinia rhomboidea Radlk. & Preênsil \\
& Serjania caracasana (Jacq.) Willd. & Preênsil \\
& Serjania fuscifolia Radlk. & Preênsil \\
& Serjania glabrata Kunth & Preênsil \\
& Serjania laruotteana Cambess. & Preênsil \\
& Serjania meridionalis Cambess. & Preênsil \\
& Serjania multiflora Cambess. & Preênsil \\
& Serjania pinnatifolia Radlk. & Preênsil \\
& Thinouia ventricosa Radlk. & Preênsil \\
Urvillea laevis Radlk. & Preênsil \\
SOLANACEAE & Lycianthes australe (Moton) A.T. Hunz. \& Barboza & Volúvel \\
& Solanum hirtellum (Spreng.) Hassl. & Escandente \\
STERCULIACEAE & Byttneria catalpifolia Jacq. & Volúvel \\
ULIGONIACEAE & Trigonia nivea Cambess. & Escandente \\
VERBENACEAE & Celtis iguanae (Jacq.) Sarg. & Escandente \\
& Petrea volubilis L. & Volúvel \\
& Cissus verticillata (L.) Nicolson \& C.E. Jarvis & Preênsil \\
\hline
\end{tabular}


Tabela 5. Listagem das espécies de lianas lenhosas amostradas no Parque Estadual Carlos Botelho e respectivas formas de escalada

\begin{tabular}{|c|c|c|}
\hline FAMÍLIA & ESPÉCIE & $\begin{array}{l}\text { FORMA DE } \\
\text { ESCALADA }\end{array}$ \\
\hline \multirow[t]{6}{*}{ APOCYNACEAE } & Forsteronia sp. & Volúvel \\
\hline & Mandevilla funiformis (Vell.) K. Schum. & Volúvel \\
\hline & Mandevilla urophylla (Hook.) Woodson & Volúvel \\
\hline & Peltastes peltatus (Vell.) Woodson & Volúvel \\
\hline & Prestonia coalita (Vell.) Woodson & Volúvel \\
\hline & Secondatia densiflora A. DC. & Volúvel \\
\hline ARISTOLOCHIACEAE & Aristolochia paulistana Hoehne & Volúvel \\
\hline ASTERACEAE & Mikania hirsutissima DC. & Volúvel \\
\hline \multirow[t]{5}{*}{ BIGNONIACEAE } & Adenocalymma grandifolium Mart. ex DC. & Preênsil \\
\hline & $\begin{array}{l}\text { Adenocalymma ternatum (Vell.) Corr. Méllo ex Bureau } \\
\& \text { K. Schum. }\end{array}$ & Preênsil \\
\hline & $\begin{array}{l}\text { Anemopaegma lanceolatum (A. DC.) Bureau ex K. } \\
\text { Schum. }\end{array}$ & Preênsil \\
\hline & Parabignonia unguiculata (Vell.) A.H. Gentry & Preênsil \\
\hline & Paragonia pyramidata (Rich.) Bureau & Preênsil \\
\hline CACTACEAE & Pereskia aculeata Mill. & Escandente \\
\hline CONNARACEAE & Connarus rostratus (Vell.) L.B. Sm. & Volúvel \\
\hline \multirow{2}{*}{ DILLENIACEAE } & Davilla sp. & Volúvel \\
\hline & Dolliocarpus dentatus (Aubl.) Standl. & Escandente \\
\hline \multirow[t]{6}{*}{ HIPPOCRATEACEAE } & Anthodon decussatum Ruiz \& Pav. & Preênsil \\
\hline & Cheiloclinium cognatum (Miers) A.C. Sm. & Preênsil \\
\hline & Peritassa sp. & Preênsil \\
\hline & Salacia elliptica (Mart. ex Schult.) G. Don & Volúvel \\
\hline & Salacia mosenii A.C. Sm. & Preênsil \\
\hline & Tontelea sp. & Preênsil \\
\hline \multirow[t]{2}{*}{ LEG. - Caesalpinioideae } & Bauhinia cf. guianensis Aubl. & Preênsil \\
\hline & Bauhinia microstachya (Raddi) J.F. Macbr. & Preênsil \\
\hline \multirow[t]{5}{*}{ LEG. - Faboideae } & Dahlstedtia pentaphylla (Taub.) Burkart & Escandente \\
\hline & Dahlstedtia pinnata (Benth.) Malme & Escandente \\
\hline & Dalbergia frutescens (Vell.) Britton & Preênsil \\
\hline & Machaerium triste Vogel & Preênsil \\
\hline & Mucuna urens (L.) Medik. & Volúvel \\
\hline LEG. - Mimosoideae & Acacia lacerans Benth. & Escandente \\
\hline LOGANIACEAE & Strychnos trinervis (Vell.) Mart. & Preênsil \\
\hline \multirow[t]{5}{*}{ MALPIGHIACEAE } & Banisteriopsis argyrophylla (A. Juss.) B. Gates & Volúvel \\
\hline & Heteropterys intermedia (Grisebach) A. Juss. & Volúvel \\
\hline & Heteropterys nitida (Lamarck) DC. & Volúvel \\
\hline & Hiraea sp. 1 & Volúvel \\
\hline & Hiraea sp. 2 & Volúvel \\
\hline MENDONCIACEAE & Mendoncia velloziana Mart. & Volúvel \\
\hline \multirow[t]{2}{*}{ MENISPERMACEAE } & Abuta selloana Eichler & Preênsil \\
\hline & Cissampelos andromorpha DC. & Volúvel \\
\hline PHYTOLACCACEAE & Seguieria floribunda Benth. & Escandente \\
\hline POLYGONACEAE & Coccoloba cf. parimensis Benth. & Volúvel \\
\hline RUBIACEAE & Sabicea villosa Willd. ex Roem. \& Schult. & Volúvel \\
\hline \multirow[t]{3}{*}{ SAPINDACEAE } & Paullinia carpopoda Cambess. & Preênsil \\
\hline & Paullinia meliifolia Juss. & Preênsil \\
\hline & Paullinia trigonia Vell. & Preênsil \\
\hline
\end{tabular}


Tabela 5. Listagem das espécies de lianas lenhosas amostradas no Parque Estadual Carlos Botelho e respectivas formas de escalada

\begin{tabular}{llc}
\hline FAMÍLIA & \multicolumn{1}{c}{ ESPÉCIE } & $\begin{array}{c}\text { FORMA DE } \\
\text { ESCALADA }\end{array}$ \\
\hline SAPINDACEAE & Serjania communis Cambess. & Preênsil \\
VIOLACEAE & Anchietea pyrifolia (Mart.) G. Don. & Volúvel \\
VITACEAE & Cissus verticillata (L.) Nicolson \& C.E. Jarvis & Preênsil \\
\hline
\end{tabular}

Tabela 6. Classificação e quantificação das lianas lenhosas, de acordo com o tipo de fixação, para a Estação Ecológica dos Caetetus e Parque Estadual Carlos Botelho

\begin{tabular}{ccccc}
\hline \multirow{2}{*}{ Tipo } & \multicolumn{2}{c}{ E.E.C. } & \multicolumn{2}{c}{ P.E.C.B. } \\
& Famílias & Espécies & Famílias & Espécies \\
\hline Preênsil & 6 & 43 & 7 & 21 \\
Volúvel & 9 & 22 & 13 & 22 \\
Escandente & 8 & 11 & 4 & 6 \\
\hline
\end{tabular}

As lianas escandentes estão representadas em menor número para as duas áreas amostradas (11 espécies na E.E.C. e 6 no P.E.C.B.). A maioria das espécies enquadradas nessa categoria apresentou espinhos como estrutura auxiliar na fixação ao forófito, sendo que as únicas sem essa adaptação foram Solanum hirtellum (Spreng.) Hassl. (Solanaceae) e Trigonia nivea Cambess. (Trigoniaceae) para a E.E.C. e Dahlstedtia pentaphylla (Taub.) Burkart e D. pinnata (Benth.) Malme (Leguminosae) para o P.E.C.B. As espécies do gênero Acacia (Leguminosae) apresentam outra adaptação que auxilia na fixação: a porção apical dos ramos encurvada. Em Cactaceae, Nyctaginaceae, Phytolaccaceae, Trigoniaceae e Ulmaceae a forma escandente foi exclusiva, ou seja, todas as espécies encontradas apresentaram esta forma de escalada. 
Quanto à forma volúvel, um elevado número de espécies (22 para cada área estudada) foi enquadrado nessa categoria. Amaranthaceae, Apocynaceae, Aristolochiaceae, Asteraceae, Connaraceae, Malpighiaceae, Mendonciaceae, Polygonaceae, Rubiaceae, Sterculiaceae, Verbenaceae e Violaceae apresentaram todos os seus representantes com esse mecanismo de escalada. Esse tipo de mecanismo que utiliza apenas os movimentos no ápice dos ramos para se fixar ao suporte, embora seja considerado menos especializado, pois supõe-se ser uma situação mais simples e primordial (Darwin, 1867) e envolver um maior gasto energético para o vegetal atingir o dossel (Maia, 1990), teve alta representatividade nas duas áreas abrangidas pelo estudo, principalmente no P.E.C.B., onde foi a categoria com um maior número de espécies. Esses dados indicam a grande importância da forma volúvel na radiação do hábito lianescente entre as famílias de plantas vasculares, como também foi observado por Lima et al. (1997).

A forma preênsil esteve ricamente representada tanto na E.E.C. como no P.E.C.B., ocorrendo respectivamente em $57 \%$ das espécies amostradas (43 espécies) e 43\% (21 espécies). São duas as estruturas preênseis deselvolvidas pelas lianas, as gavinhas, que podem ser de origem foliar ou caulinar, e os ganchos, que são de origem caulinar (Lima et al., 1997). Quanto à ocorrência dessas estruturas, as gavinhas estiveram presentes na grande maioria das espécies (em 40 na E.E.C. e em 13 no P.E.C.B.). Bignoniaceae, Leguminosae, Loganiaceae, Rhamnaceae e Sapindaceae possuíam representantes com gavinhas, as quais eram de origem foliar em Bignoniaceae e caulinar nas demais. A única família que não apresentou exclusividade para essa estrutura, dentre as preênseis, foi Leguminosae. Os ganchos estiveram presentes apenas em Hippocrateaceae, Leguminosae e Menispermaceae.

O grande número de espécies com estruturas preênseis e o reduzido número de famílias onde elas ocorrem, considerando as áreas de estudo, 
reforçam as indicações propostas por Gentry (1991), de que em regiões neotropicais o nível mais elevado de especialização no hábito lianescente, especialmente aquele associado a estruturas fixadoras como gavinhas, atingiu apenas algumas famílias.

As gavinhas apresentam uma morfologia bastante diversificada e, por este motivo, apresentam um importante valor do ponto de vista taxonômico, não só para o reconhecimento de algumas famílias, como também para a determinação de gêneros e espécies. Para exemplificar, na família Bignoniaceae, as gavinhas podem ser simples, como em Adenocalymma, ramificadas em Mansoa e Pithecoctenium e, além de serem ramificadas, podem ser uncinadas, como em Macfadyena e Parabignonia, ou ainda apresentar discos adesivos nos terminais, como ocorre em Glaziovia.

Uma variação morfológica observada que merece destaque refere-se à forma de vida. Algumas espécies podem apresentar mais de um hábito, dependendo das condições climáticas a que estão expostas, ou ainda, sob as mesmas pressões ambientais, podem apresentar plasticidade nessa característica. Nas áreas onde foi realizado o estudo, tal fato foi observado em Seguieria floribunda Benth. (Phytolaccaceae) e nas espécies de Dahlstedtia (Leguminosae) que, além de apresentarem hábito lianescente, podem ocorrer com a forma arbustivo-arbórea.

Tanto na E.E.C. quanto no P.E.C.B. algumas espécies de lianas lenhosas exibiram desenvolvimento heteroblástico. Givnish \& Vermeij (1976) verificaram que as folhas, ao longo de um perfil vertical na floresta, são pequenas na sombra, aumentam de tamanho conforme passam para pontos mais altos e voltam a diminuir nas condições ensolaradas do dossel. Essa variação de tamanho de folha segundo um gradiente vertical foi observada para várias espécies durante este estudo. Na E.E.C. ocorreu em Forsteronia pubescens DC. (Apocynaceae), em muitas espécies de Bignoniaceae (Adenocalymma marginatum 
(Cham.) DC., Adenocalymma paulistarum Bureau \& K. Schum., Arrabidaea conjugata (Vell.) Mart., Lundia obliqua Sonder, Macfadyena mollis (Sond.) Seem., Macfadyena unguis-cati (L.) A.H. Gentry e Stizophyllum perforatum (Cham.) Miers), Bauhinia microstachya (Raddi) J.F. Macbr. (Leguminosae), Mascagnia cordifolia (A. Juss.) Griseb. (Malpighiaceae) e em Gouania acalyphoides Reissek (Rhamnaceae). Já no P.E.C.B. essa variação foi observada em apenas três espécies, Aristolochia paulistana Hoehne (Aristolochiaceae), Adenocalymma ternatum (Vell.) Corr. Méllo ex Bureau \& K. Schum. (Bignoniaceae) e Bauhinia microstachia (Raddi) J.F. Macbr. (Leguminosae).

Um exemplo clássico de desenvolvimento heteroblástico ocorre no gênero Macfadyena (Bignoniaceae). As plântulas de M. unguis-cati (L.) A.H. Gentry se desenvolvem em indivíduos jovens com folhas bifolioladas, cada folha desenvolve uma gavinha uncinada e trífida e, depois de ascender, a liana produz raízes adventícias e grandes folhas bifolioladas que perdem as gavinhas (Lee \& Richards, 1991). Para a E.E.C. foi observado que os indivíduos jovens de M. mollis (Sond.) Seem. apresentam raízes adventícias que fixam a liana no forófito e, conforme ascendem, perdem essas raízes e as folhas, bifolioladas, passam a desenvolver uma gavinha uncinada e trífida. Uma outra característica dessas espécies, o que inclusive torna difícil o posicionamento entre as categorias de forma de vida, refere-se ao fato de ocorrerem germinando tanto no solo quanto no forófito. Considerando apenas essas observações é praticamente impossível afirmar se essas plantas são lianas, apresentando hemiepifitismo eventual, ou verdadeiramente hemiepífitas. Para isso, são necessários estudos futuros que acompanhem o desenvolvimento das espécies, verificando se há dependência do solo para a continuidade do desenvolvimento. 


\section{CONCLUSÕES}

- O termo liana deve ser empregado para todas as plantas lenhosas ou herbáceas que utilizam um forófito como suporte durante a maior parte de seu desenvolvimento e que mantém um contato permanente com o solo (são dependentes do solo).

- Para a Estação Ecológica dos Caetetus foram amostradas 76 espécies de lianas lenhosas, distribuídas em 52 gêneros, num total de 19 famílias. Já no Parque Estadual Carlos Botelho ocorreram 49 espécies, 40 gêneros e 19 famílias.

- As famílias mais ricas foram Bignoniaceae (26 spp.), Sapindaceae (11 spp.), Apocynaceae (7 spp.), Malpighiaceae (7 spp.) e Leguminosae (6 spp.) para a E.E.C. e Leguminosae (7 spp.), Apocynaceae (6 spp.), Hippocrateaceae (6 spp.), Bignoniaceae (5 spp.) e Malpighiaceae (5 spp.) para o P.E.C.B.. Portanto, são poucas famílias que detém um grande número de espécies, sendo que este sucesso adaptativo das lianas está relacionado às especializações nos mecanismos de fixação ao forófito.

- Quanto às formas de fixação, na E.E.C. a forma preênsil esteve presente na maioria das espécies (57\%), seguida pelas formas volúvel (29\%) e escandente (14\%). No P.E.C.B. a forma volúvel foi a que apresentou maior destaque, estando presente em $45 \%$ das espécies amostradas, seguida pelas formas preênsil (43\%) e escandente (12\%). 


\subsection{Considerações finais}

Esta parte do trabalho foi destinada à apresentação de alguns dados observados em campo e que permitem alguns comentários no sentido de incentivar a realização de estudos que averigúem a autenticidade por um caminho científico, ou seja, aplicando uma metodologia adequada para cada caso:

- Nas coletas em sub-parcelas na E.E.C. algumas espécies foram encontradas exclusivamente em clareiras, sendo elas Adenocalymma marginatum (Cham.) DC. e Arrabidaea conjugata (Vell.) Mart. (Bignoniaceae), Acacia plumosa Lowe (Leguminosae), Lycianthes australe (Morton) A.T. Hunz. \& Barboza e Solanum hirtellum (Spreng.) Hassl. (Solanaceae). Essas espécies que foram encontradas em clareiras também foram as mais abundantes nessa situação. Para o P.E.C.B. (nas subparcelas), três espécies foram encontradas exclusivamente nas clareiras, sendo elas Aristolochia paulistana Hoehne (Aristolochiaceae), Adenocalymma ternatum (Vell.) Corr. Méllo ex Bureau \& K. Schum. (Bignoniaceae) e Acacia lacerans Benth. (Leguminosae), das quais a segunda foi a mais abundante em tal situação. $O$ fato de algumas espécies terem ocupação favorecida em regiões de clareiras pode estar relacionado às diferentes exigências por luz apresentadas pelas mesmas.

- Com relação à ocorrência das espécies, algumas foram encontradas uma única vez ao longo dos estudos, podendo talvez ser enquadradas em uma categoria de rara ocorrência para os locais estudados. Para a E.E.C., três espécies enquadram-se nessa situação, sendo elas Arrabidaea pulchella Bureau, Tynanthus micranthus Corr. Méllo ex K. Schum. (ambas Bignoniaceae) e Serjania glabrata Kunth (Sapindaceae). A partir das consultas aos acervos dos herbários, pôde ser verificado que a primeira espécie é muito freqüente em áreas de Cerradão, como em Corumbataí e 
na Estação Ecológica de Assis e as outras duas são freqüentes em outras florestas estacionais semidecíduas. Para o P.E.C.B. também foram 3 espécies, sendo elas Banisteriopsis argyrophylla (A. Juss.) B. Gates, Hiraea sp.1 (ambas Malpighiaceae) e Coccoloba cf. parimensis Benth. (Polygonaceae).

- Como o P.E.C.B. apresenta uma área muito grande e, por este motivo, engloba regiões muito distintas do ponto de vista florístico, como já foi enfatizado na metodologia, áreas com altitude mais elevada não foram consideradas no presente estudo. Apesar disso, foram realizadas algumas expedições de coleta para a região de maior altitude (Núcleo São Miguel Arcanjo) e, a título de curiosidade, foram encontradas nessa região algumas espécies de lianas lenhosas que não ocorreram em altitudes mais baixas, na área onde foi realizada a amostragem: Adenocalymma trifoliatum (Vell.) Laroche, Anemopaegma prostratum DC. (ambas Bignoniaceae) e Fuchsia regia (Vell.) Munz (Onagraceae).

- As lianas herbáceas, apesar de não terem sido abordadas nesse estudo, foram freqüentemente observadas habitando as bordas das florestas e clareiras. Famílias como Asclepiadaceae, Dioscoriaceae e Passifloraceae, para a E.E.C., e Cucurbitaceae, Smilacaceae e Vitaceae, para o P.E.C.B., foram observadas no sub-bosque e, aparentemente, não atingem o estrato superior, o que vem a demonstrar a relevante participação das lianas herbáceas para a diversidade florística das comunidades que ocupam o interior sombreado da floresta.

- Uma característica que foi observada na E.E.C. refere-se às espécies de lianas lenhosas encontradas em clareiras. Algumas das espécies que ocorrem com maior freqüência nessas áreas apresentam uma forma de crescimento que pode ser considerada agressiva. As espécies com essas características foram Arrabidaea conjugata (Vell.) Mart. (Bignoniaceae), 
Acacia plumosa Lowe (Leguminosae), Serjania caracasana (Jacq.) Willd. e Serjania laruotteana Cambess. (Sapindaceae) que, além de ocorrerem nas clareiras, puderam ser encontradas em alguns pontos da região de borda, onde também apresentaram essa forma de ocupação, pois estavam claramente interferindo, de forma negativa, no desenvolvimento das árvores utilizadas como forófitos. Dentre as espécies citadas acima, apenas as Sapindaceae foram encontradas no sub-bosque, em locais sombreados. Para a área abrangida pelo estudo no P.E.C.B. não foram encontradas espécies que apresentassem uma forma de ocupação considerada agressiva. Portanto, quando se trata da recuperação de uma área não é correto afirmar que todas as espécies de lianas são agressivas e que necessitam de manejo. Sendo assim, o ideal seria, em um primeiro momento, identificar quais são essas espécies e acompanhar a fenologia das mesmas, para, a partir de então, traçar medidas racionais de manejo. 
ANEXOS 


\begin{abstract}
ANEXO A
RESUMO DO PROJETO TEMÁTICO “DIVERSIDADE, DINÂMICA E CONSERVAÇÃO EM FLORESTAS DO ESTADO DE SÃO PAULO: 40 ha DE PARCELAS PERMANENTES"
\end{abstract}

O projeto "Diversidade, dinâmica e conservação em florestas do Estado de São Paulo: 40 ha de parcelas permanentes", coordenado pelos Profs. Drs. Ricardo Ribeiro Rodrigues, Vinicius Castro Souza e Alexandre Adalardo de Oliveira, será desenvolvido em quatro Unidades de Conservação (Parque Estadual Ilha do Cardoso, Parque Estadual Carlos Botelho, Estação Ecológica dos Caetetus e Estação Ecológica de Assis), que representam as quatro principais formações florestais do Estado de São Paulo: Formações Pioneiras com Influência Marinha (Floresta de Restinga), Floresta Ombrófila Densa (Floresta Atlântica de Encosta), Floresta Estacional Semidecídua e Savana Florestada (Cerradão), cada uma sendo constituída por um componente florístico, estrutural e funcional característico e de fundamental importância.

O conhecimento disponível nos estudos já realizados sobre as formações florestais remanescentes do Estado de São Paulo ainda não permite que sejam abordadas, de forma satisfatória, suposições sobre os mecanismos reguladores da biodiversidade nesses fragmentos e como as alterações recentes e perturbações periódicas interferem nos processos da dinâmica florestal. Deste 
modo, o trabalho e a dedicação dos botânicos e ecólogos para a descrição dos elementos e processos ocorrentes nesses remanescentes precisa ainda ser incentivada, priorizando os esforços também para o entendimento dos processos reguladores da dinâmica florestal e dos mecanismos promotores e mantenedores da diversidade.

Este conhecimento é primordial para o estabelecimento de ações pertinentes de conservação, manejo e recuperação destas formações e de indicadores de avaliação e monitoramento destas áreas remanescentes. Neste contexto, a amostragem de grandes trechos de remanescentes florestais pertencentes a diferentes unidades fitogeográficas do sub-trópico, com reavaliações periódicas, visando uma descrição aprofundada dos elementos ambientais caracterizadores e diferenciadores destas unidades, através do acúmulo de séries temporais de dados, é imprescindível para uma interpretação consistente dos processos ecológicos envolvidos na dinâmica florestal de cada uma destas unidades e a sua diferenciação com relação às formações tipicamente tropicais.

Deve ser salientado que a principal perspectiva do projeto é disponibilizar grandes trechos das principais formações florestais do Estado de São Paulo com dados físicos (solo, topografia, umidade, pluviosidade, etc) e vegetacionais (florística, estrutura, alterações temporais, etc) detalhados, para estudos ecológicos nas mais diversas áreas do conhecimento, como estudos em biologia floral e reprodutiva, faunística, etc. Dessa forma será possível acumular conhecimento sobre diferentes processos ecológicos e assim gerar modelos mais integrados e amplos do ecossistema. A existência de uma base sólida de dados temporais de florestas remanescentes, oriunda dos estudos de amostragem em larga-escala são ainda de grande auxílio para a seleção de espécies potencialmente interessantes para o manejo florestal, incluindo os sistemas agroflorestais. 
Os dados gerados nesses projetos serão confrontados com aqueles gerados em parcelas permanentes já estabelecidas em diferentes regiões do mundo, permitindo identificar os padrões gerais e as particularidades das florestas tropicais e sub-tropicais, inserindo os estudos das florestas paulistas no contexto mundial e subsidiando o estabelecimento e a consolidação de uma política ambiental consistente para a conservação da diversidade do Estado de São Paulo.

Dentro de cada U.C. o trecho a ser amostrado com a parcela permanente será definido segundo alguns critérios de seleção: o estado de conservação, a representatividade regional das características do ambiente (tipo de solo, declividade, condição fitogeográfica na paisagem, interações ecotonais, etc), a disponibilidade de expansão futura da área amostral e as condições de acesso. No que se refere à conservação, serão definidos trechos centrais (core) da U.C., evitando-se áreas próximas à borda ou em limites de estradas, bem como descargas de águas superficiais, áreas de cultivos, etc.

O trecho de vegetação escolhido em cada unidade deve representar as variações regionais dominantes naquele tipo vegetacional para alguns fatores abióticos, como por exemplo variações edáficas na Floresta Estacional Semidecídua e no Cerradão, variações altitudinais na Floresta Ombrófila Densa de Encosta e variações na influência marinha para a Floresta de Restinga, permitindo relacioná-las com possíveis fatores reguladores e mantenedores da biodiversidade, das variações populacionais e dos processos ecológicos em geral.

Em cada área amostrada será feita a caracterização detalhada do solo (três profundidades em cada parcela) e da topografia (escala 1:500), e a caracterização continuada (4 anos) do clima, do lençol freático e da luz, considerando todas as unidades do mosaico florestal e também a caracterização da fauna microbiana do solo, através do perfil de $16 \mathrm{~S}$ rDNA gerado pelo método 
de DGGE. Para a vegetação será feita uma caracterização das espécies arbóreas ocorrentes em cada área e a elaboração de guias práticos ilustrados de reconhecimento de campo de todas as espécies florestais amostradas.. Em cada área selecionada será alocada uma parcela de $320 \times 320 \mathrm{~m}$, totalizando 10,24 ha ou $102.400 \mathrm{~m}^{2}$, subdividida em 256 sub-parcelas de $20 \times 20 \mathrm{~m}\left(400 \mathrm{~m}^{2}\right)$. A parcela maior vai ser alocada usando imagens geradas com videografia multiespectral Essa alocação da parcela maior e sub-parcelas na área será feita por equipe especializada de topografia, usando teodolito de alta precisão. Tanto a parcela como as sub-parcelas serão delimitadas com estacas permanentes. Essas estacas serão construídas usando tubos de PVC de 1,5 m de altura (3/4" de diâmetro) preenchidos com cimento e com uma barra de ferro de $1 / 2$ ".

Esta mesma equipe topográfica será também responsável pela marcação, numeração e mapeamento de todos os indivíduos arbóreos com DAP (diâmetro à altura do peito) igual ou superior a 4,8 cm (PAP - perímetro à altura do peito $\geq 15,0 \mathrm{~cm}$ ). Esta medida foi definida para possibilitar a comparação com os dados provenientes da maioria dos trabalhos realizados nas florestas do Estado de São Paulo.

O levantamento planialtimétrico de cada trecho florestal será realizado em escala de 1:500, locando os vértices de cada sub-parcela de $20 \times 20 \mathrm{~m}$. As informações serão levantadas com uso de estação total, com precisão angular nominal de $1 \mathrm{~mm}$, com respestivos acessórios como prismas, trenas e bastões telescópios. As informações serão armazenadas em arquivo ttxt e o cálculo topográfico será feito usando o programa TOPOESALQ 3.0, desenvolvido pelo Departamento de Engenharia Rural da ESALQ/USP e as plantas baixadas serão editadas em Autocad, gerando arquivos .dwg e .dxf.

Na caracterização edáfica, a cartografia de solos será realizada com apoio de técnicas de geoprocessamento. O mapeamento de solos será realizado de duas formas: a) mapa de solos e b) mapas temáticos. 
No mapa de solos, as classes ou unidades de mapeamento serão definadas por características morfogenéticas seguindo o Sistema Brasileiro de Classificação de Solos.

Visando dispor de dados climáticos que permitam correlações com os dados vegetacionais, em cada uma das áreas será instalada uma estação meteorológica que fornecerá continuamente dados básicos como temperatura, pressão, umidade relativa do ar e do solo, precipitação vertical e horizontal, velocidade e direção do vento, radiação global, radiação fotossinteticamente ativa e outros. Estes registros serão coletados continuamente em cada área de estudo por um "data logger", que ficará ligado à estação meteorológica 24 horas por dia.

Considerando-se que os níveis de radiação solar estão entre os principais fatores que determinam a distribuição espacial das espécies arbustivo-arbóreas e a dinâmica das florestas, a caracterização dos regimes de luz existentes nos trechos florestais em estudo será feita com grande detalhamento, em diferentes escalas temporais (mensal, estacional e anual) e espaciais (área total, unidades ecológicas, estratos, clareiras e outros). 

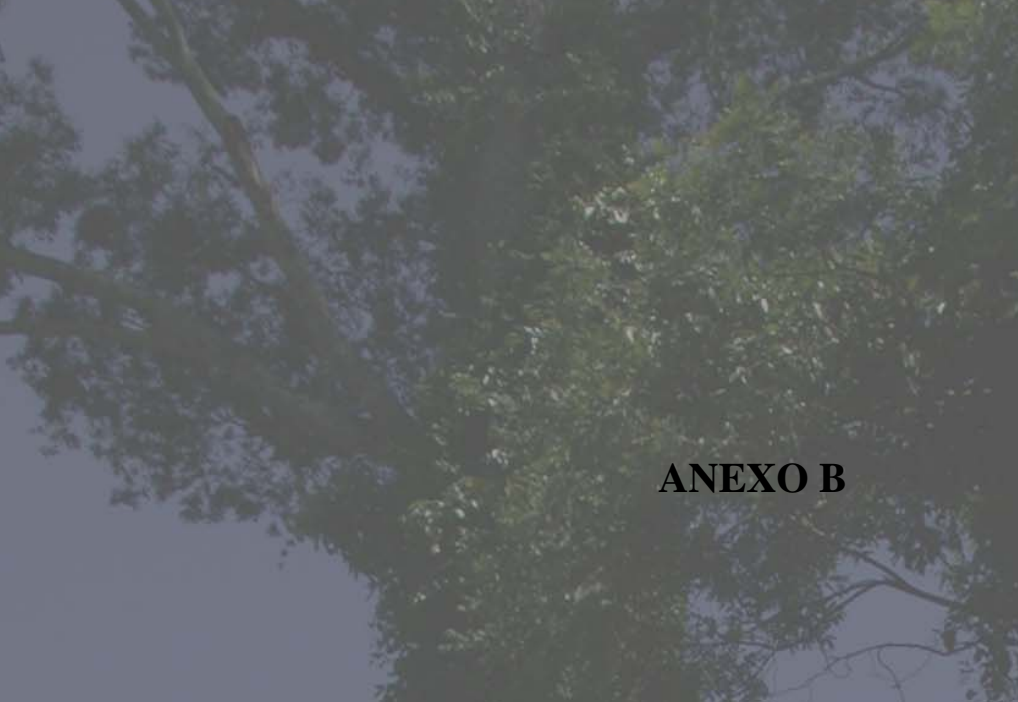

Guia Illustrado de Campo para Identificação das Espécies de

\section{Lianas Lenhosas de um Trecho de}

\section{Floresta Estacional Semidecídua na} Estação Ecológica dos Caetetus

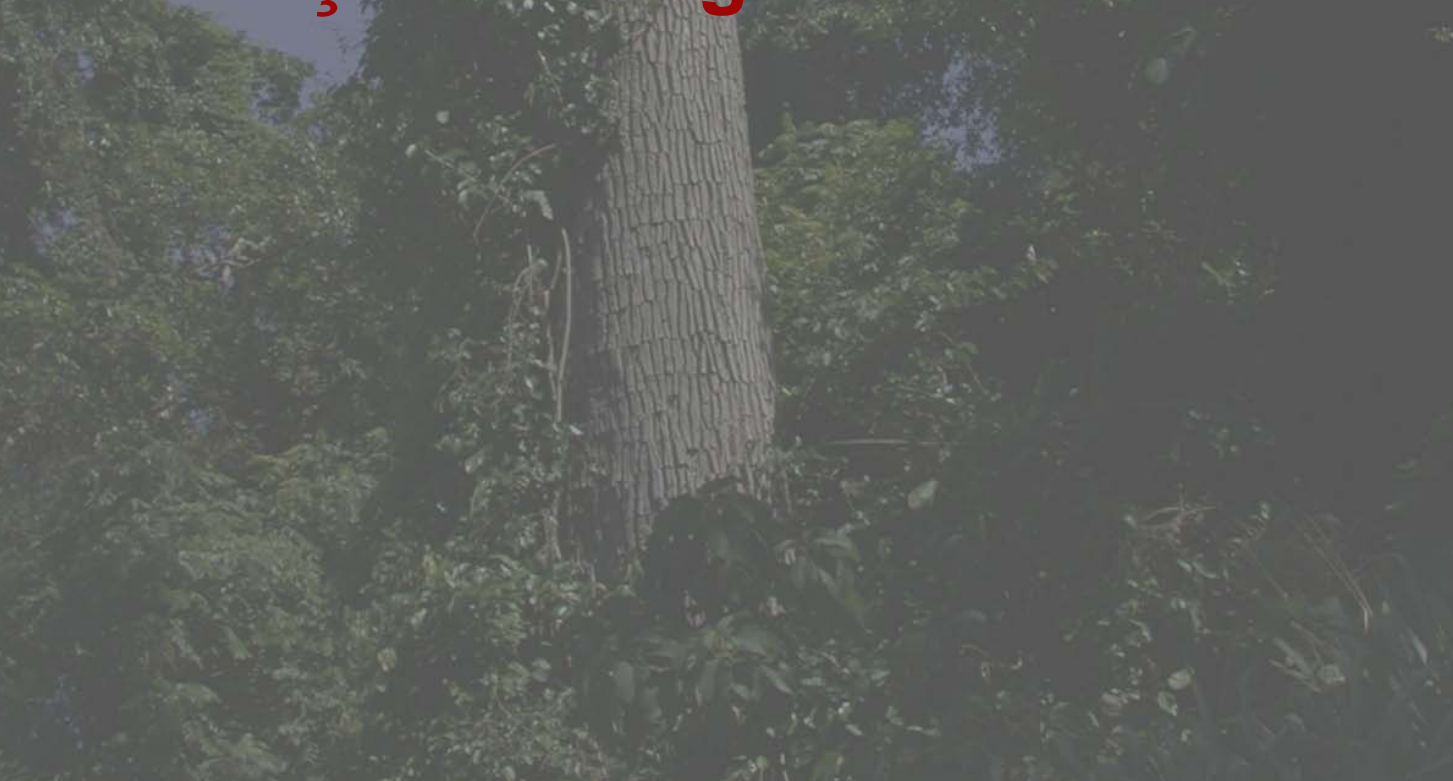

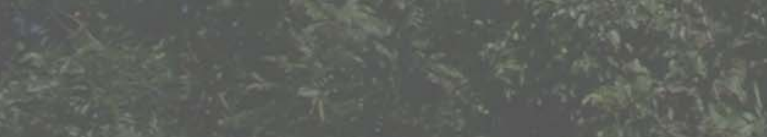




\section{CHAVE DE IDENTIFICAÇÃO PARA AS FAMÍLIAS BASEADA APENAS NAS ESPÉCIES AMOSTRADAS}

1. Folhas compostas

2. Folhas opostas

Bignoniaceae (Pág. 55)

2 '. Folhas alternas

3'. Plantas sem gavinhas

Leguminosae (Pág. 68)

3. Plantas com gavinhas

Leguminosae (Pág. 68)

4. Folhas bifolioladas

Sapindaceae (Pág. 74)

$4^{\prime}$. Folhas com 3 ou mais folíolos

$1^{\prime}$. Folhas simples

5. Folhas opostas

6. Plantas com látex

Apocynaceae (Pág. 51)

6'. Plantas sem látex

7. Caule com espinhos

Nyctaginaceae (Pág. 72)

$7^{\prime}$. Caules inermes

8. Nectários extraflorais no limbo foliar ou pecíolo; tricomas malpiguiáceos (em forma de “ $\mathrm{T}$ ”) presentes

Malpighiaceae (Pág. 70)

8 '. Nectários extraflorais e tricomas malpiguiáceos ausentes

9. Caule e folhas glabros

Hippocrateaceae (Pág. 67)

$9^{\prime}$. Caule e folhas pubescentes

Amaranthaceae (Pág. 51)

$5^{\prime}$. Folhas alternas ou sub-opostas

10. Plantas com espinhos

11. Folhas carnosas, com apenas a nervura central evidente

Cactaceae (Pág. 65)

$11^{\prime}$. Folhas papiráceas ou cartáceas, com nervuras principal e secundárias bem evidentes

12. Nós com 1 espinho Nyctaginaceae (Pág. 72)

$12^{\prime}$. Nós com 2 espinhos Phytolaccaceae (Pág. 73)

10'. Plantas inermes

13. Plantas com gavinhas 
14. Gavinhas opostas às folhas Vitaceae (Pág. 79)

$14^{\prime}$. Gavinhas na axila das folhas Rhamnaceae (Pág. 73)

13. Plantas sem gavinhas

15'. Face inferior das folhas com tricomas simples ..... Dilleniaceae (Pág. 66)

15. Face inferior das folhas com tricomas estrelados ou dendríticos

16. Folhas peninérveas Solanaceae (Pág. 78)

$16^{\prime}$. Folhas palminérveas Sterculiaceae (Pág. 79) 


\section{Amaramthaceae}

Família com ocorrência tanto nas regiões tropicais quanto nas temperadas, sendo bem representada nos continentes africano e americano. Apresenta cerca de 900 espécies, distribuídas por 65 gêneros. No Brasil ocorrem ca. de 86 espécies e 12 gêneros, sendo os mais freqüentes Alternanthera, Telanthera, Gomphrena e Philoxerus. Na área foi encontrada uma única espécie de liana lenhosa, Hebanthe paniculata.

Em geral, a família é caracterizada pelo hábito herbáceo e folhas simples, opostas ou alternas. A inflorescência é do tipo espiga ou glomérulo, sempre axilar. As flores são monoclamídeas; os estames monadelfos e alternados por estaminódios lacerados. Os frutos apresentam tépalas persistentes.

Muitas espécies são cultivadas como ornamentais e utilizadas na medicina popular e na alimentação.

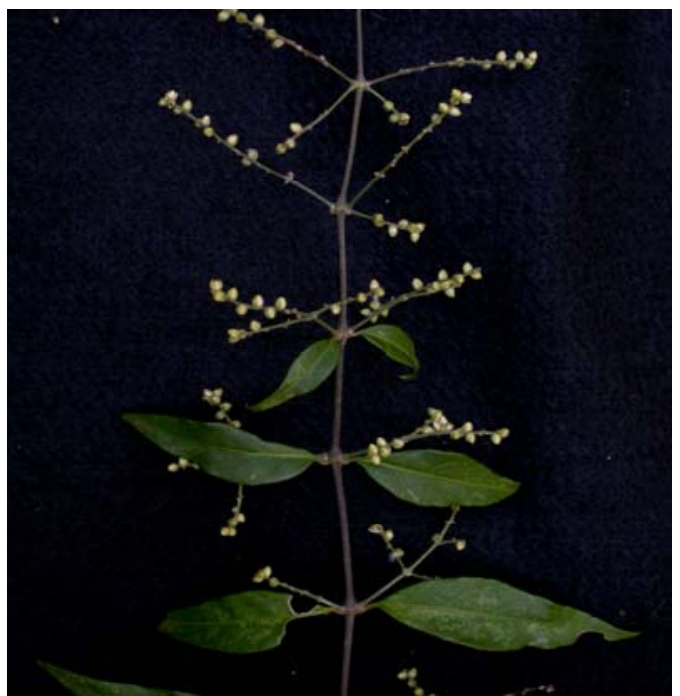

Hebanthe paniculata Mart.

\section{DICA DE CAMPO}

Esta espécie pode ser caracterizada por apresentar folhas e caule pubescentes, o que a difere das Hippocrateaceae, que também apresentam folhas simples e alternas.

\section{Apocynaceae}

Apocynaceae é uma família com cerca de 415 gêneros e 4.500 espécies, amplamente distribuída por regiões tropicais e subtropicais, com poucos representantes em regiões temperadas. No Brasil ocorrem cerca de 41 gêneros e 400 espécies. Para a área foram registrados 4 gêneros e 6 espécies.

O hábito nesse grupo é bastante variável, podendo ocorrer, além de lianas, ervas, arbustos e árvores. São plantas geralmente com látex alvo e abundante. As flores são bissexuais e geralmente vistosas, com corola tubulosa e os lobos torcidos no botão (prefloração contorta). Os filetes são unidos ao tubo da corola.

Recentemente, a partir de estudos moleculares, foi incluída nesta família as “Asclepiadaceae”.

\section{CHAVE DE IDENTIFICAÇÃO}

1. Folhas verticiladas Condylocarpon isthmicum

$1^{\prime}$.Folhas opostas

2. Domácias na superfície abaxial das folhas

3. Domácias urceoladas e pilosas Forsteronia australis

3’. Domácias não urceoladas, mas pilosas

4. Folhas com base arredondada Forsteronia pubescens

$4^{\prime}$. Folhas com base cordada Forsteronia pilosa

2’.Superfície abaxial das folhas sem domácias

5. Caule conspicuamente lenticelado; folhas com nervuras secundárias oblíquas em relação à nervura principal Prestonia coalita

5'. Caule sem lenticelas; folhas com nervuras secundárias sub-patentes 


\section{Apocynaceae}
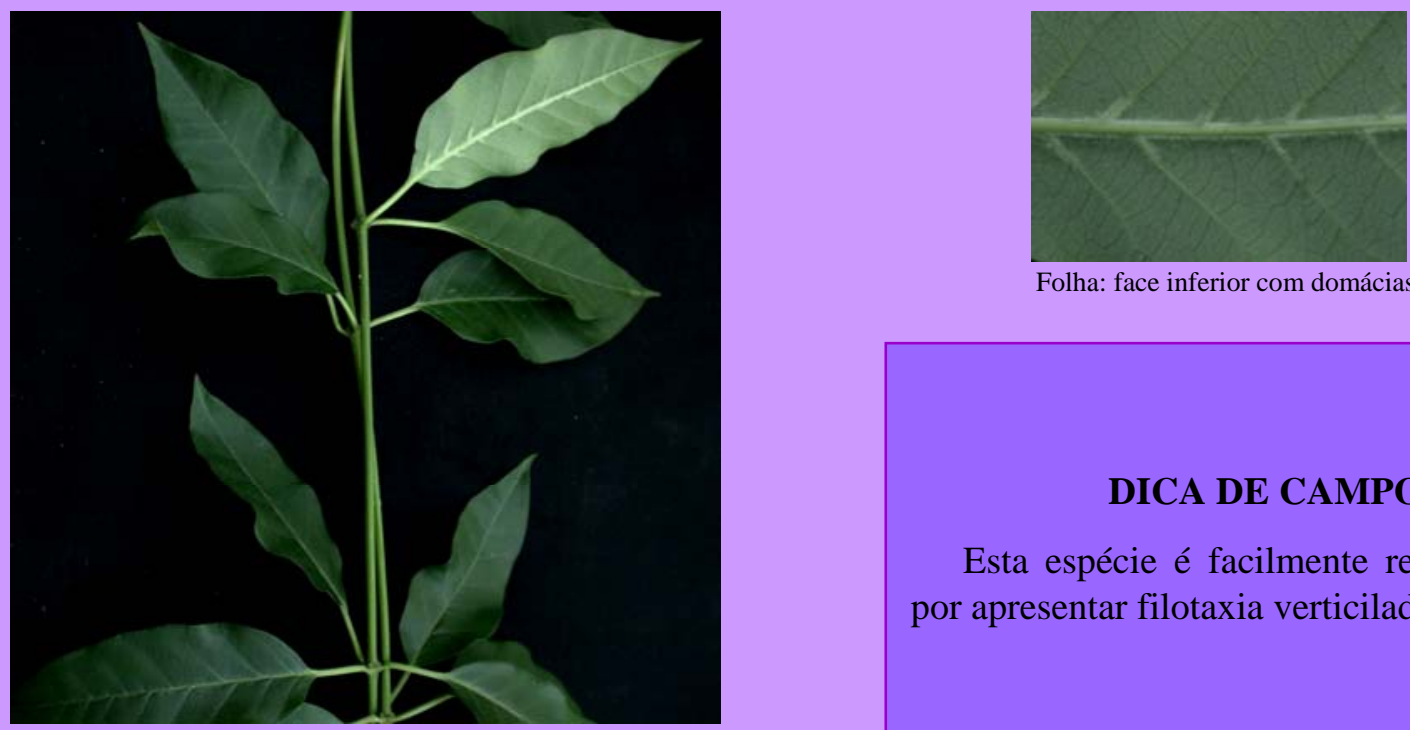

Folha: face inferior com domácias

\section{DICA DE CAMPO}

Esta espécie é facilmente reconhecida por apresentar filotaxia verticilada.

Condylocarpon isthmicum (Vell.) A. DC.

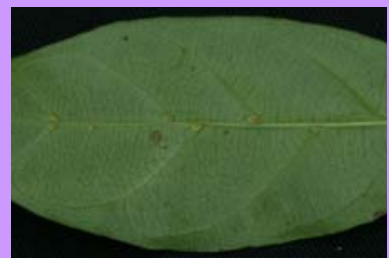

Folha: face inferior com domácias

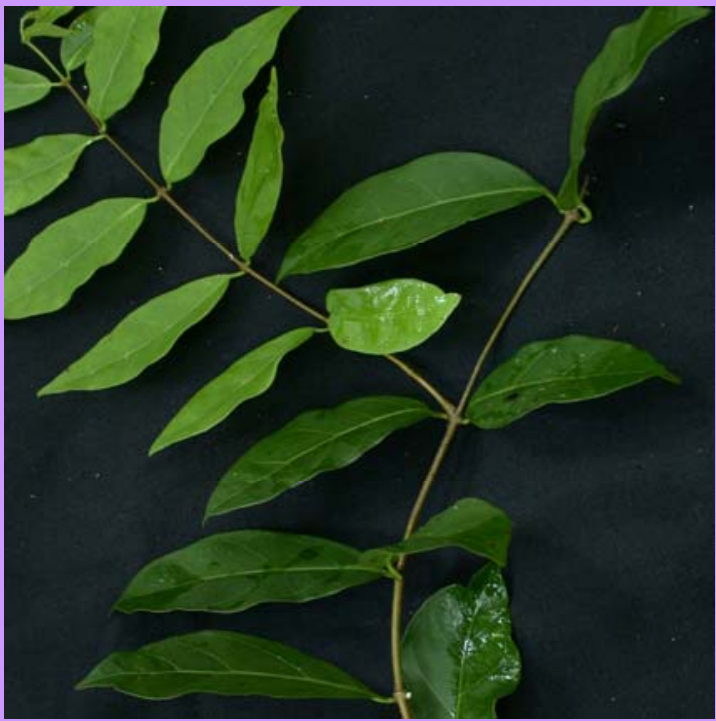

Forsteronia australis Müll. Arg.

DICA DE CAMPO

Esta espécie diferencia-se das demais Apocynaceae encontradas na área por apresentar domácias urceoladas. 


\section{Apocynaceae}

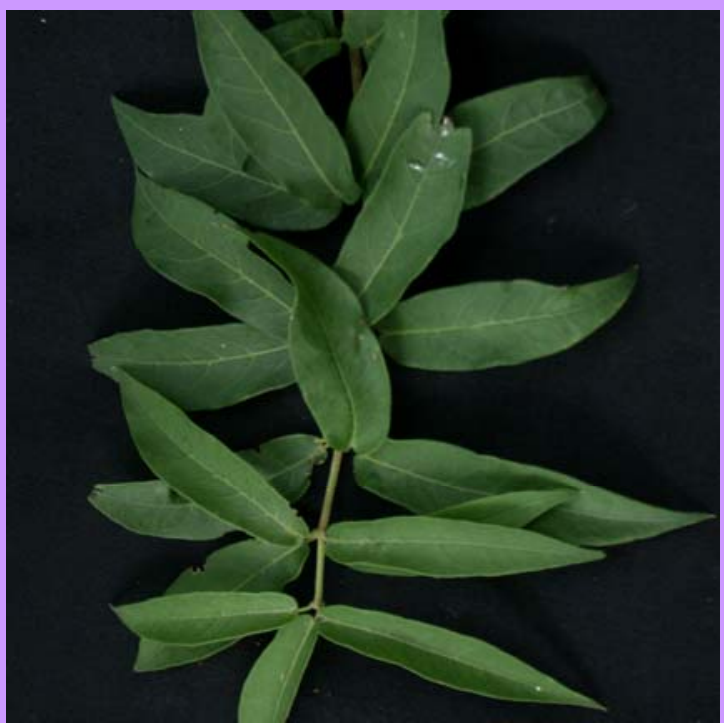

Forsteronia pilosa (Vell.) Müll. Arg.

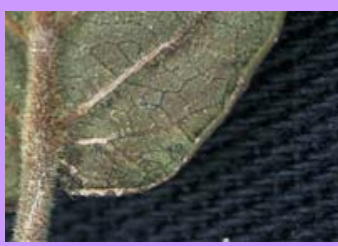

Folha: base cordada

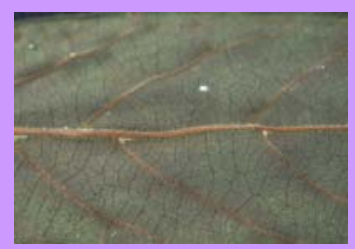

Folha: face inferior com domácias

\section{DICA DE CAMPO}

Além de apresentar domácias pilosas, esta espécie apresenta folhas com base cordada.

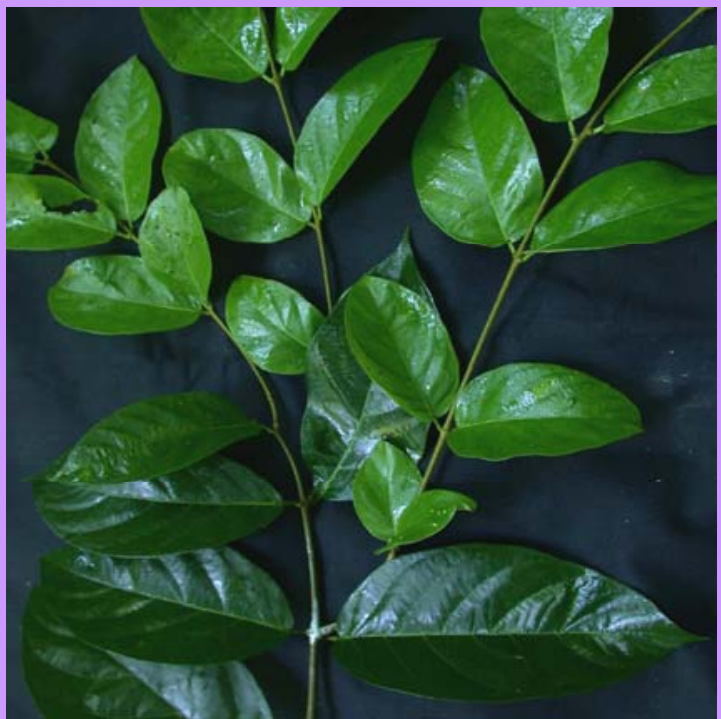

Forsteronia pubescens A. DC.

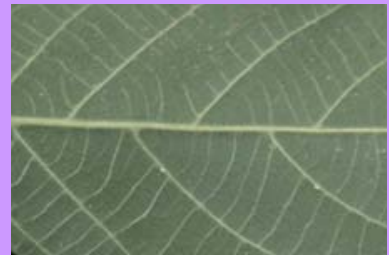

Folha: face inferior

\section{DICA DE CAMPO}

Assim como Forsteronia pilosa, apresenta domácias pilosas, mas difere da mesma por apresentar folhas com base arredondada. 


\section{Apocynaceae}

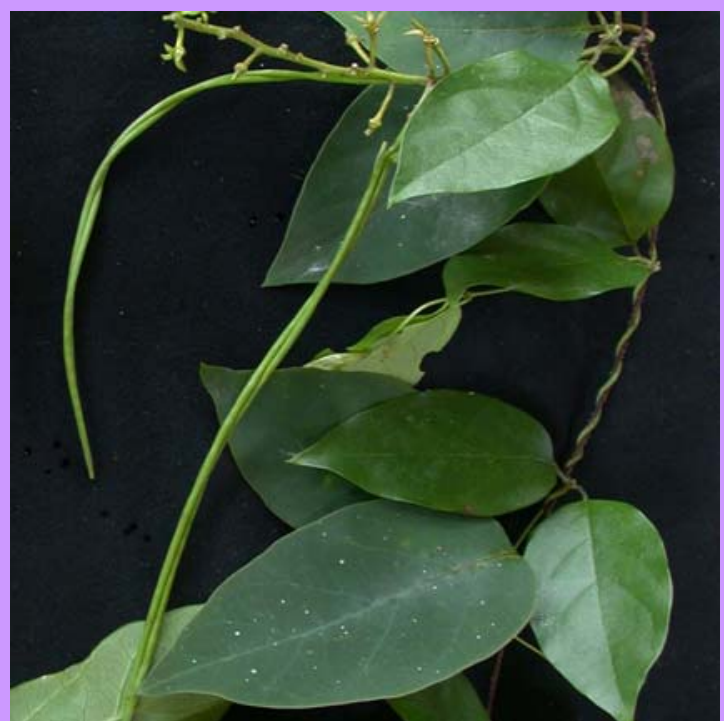

Prestonia coalita (Vell.) Woodson

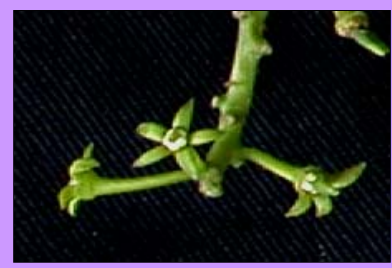

Detalhe do cálice

\section{DICA DE CAMPO}

Esta espécie, além de não possuir domácias, apresenta caule com muitas lenticelas e as nervuras secundárias das folhas são oblíquas em relação à nervura principal.

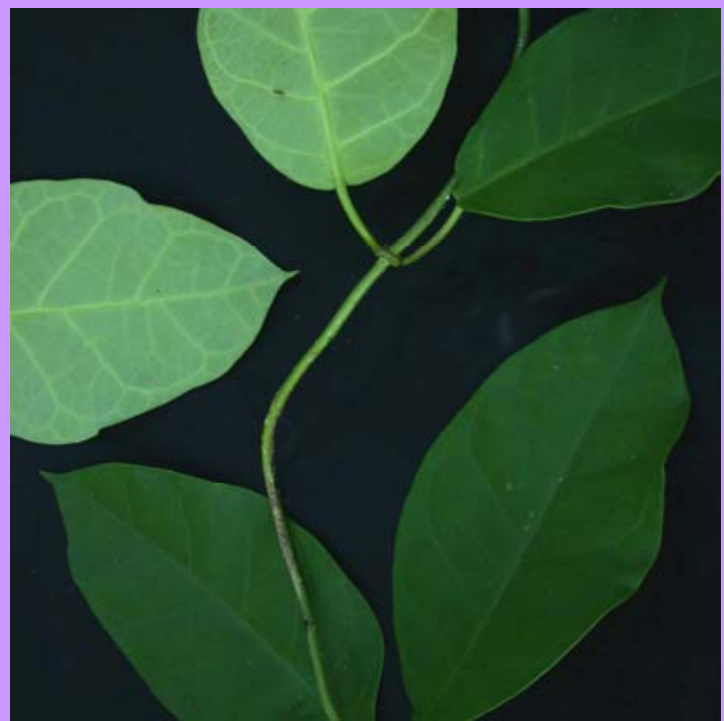

Temnadenia violacea (Vell.) Miers

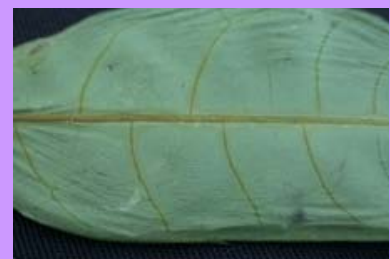

Folha: face superior

DICA DE CAMPO

Planta com folhas glabras e sem domácias. O caule não apresenta lenticelas e as nervuras secundárias das folhas são sub-patentes. 


\section{Bignoniaceae}

Família com cerca de 800 espécies e 113 gêneros, distribuídos por 8 tribos. Apresenta distribuição predominantemente neotropical, com poucas espécies nas regiões temperadas. Nas florestas estacionais semidecíduas do Estado de São Paulo é a família mais representativa em número de espécies de lianas.

No trecho do fragmento estudado é representada por 17 espécies e 13 gêneros. As lianas dessa família podem facilmente ser reconhecidas no campo pelos nós espessados, mesmo após a queda das folhas, que são opostas e compostas, pelo floema arranjado em forma de cruz na maioria das espécies e pelo folíolo terminal geralmente modificado em gavinha, a qual pode ser simples ou ramificada. As flores são caracterizadas por apresentar corola gamopétala, 4 estames didínamos, um estaminódio e estigma bífido. Os frutos, em geral, são cápsulas achatadas, com sementes aladas.

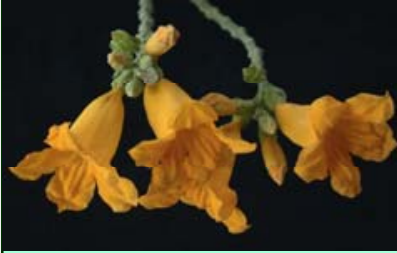

Adenocalymma marginatum

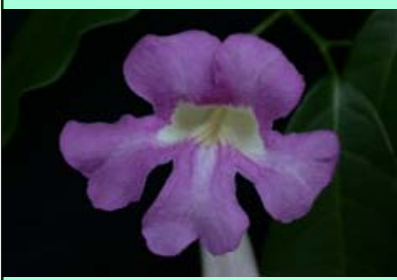

Clytostoma sciuripabulum

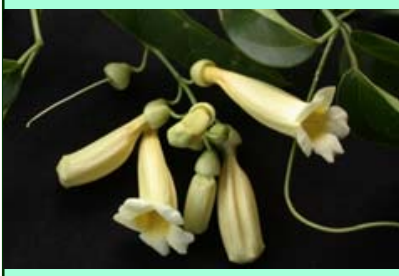

Anemopaegma chamberlaynii

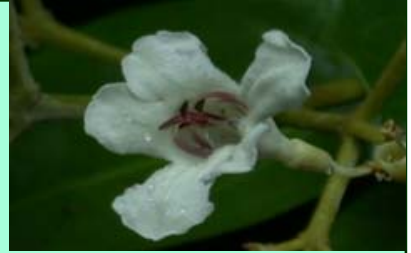

Arrabidaea florida

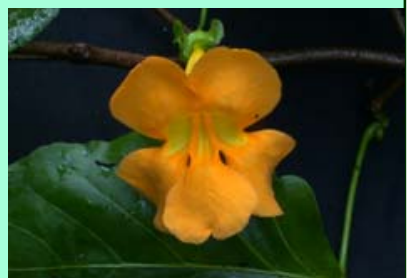

Macfadyena unguis-cati

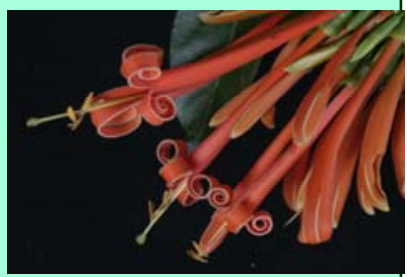

Pyrostegia venusta

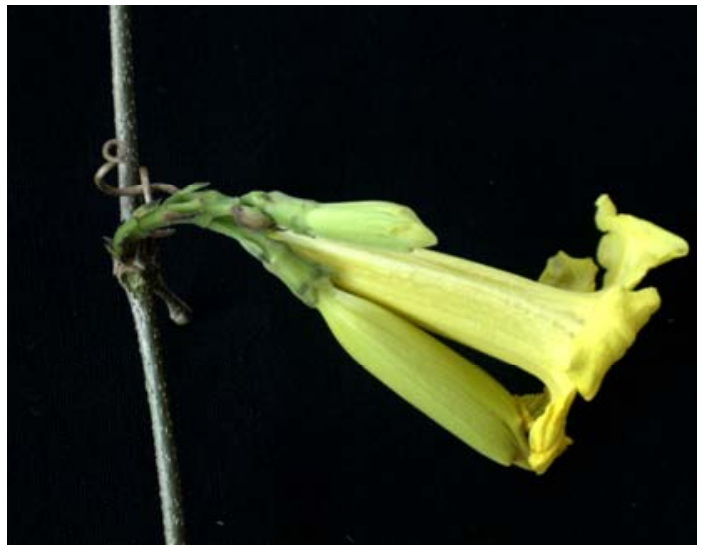

Adenocalymma paulistarum

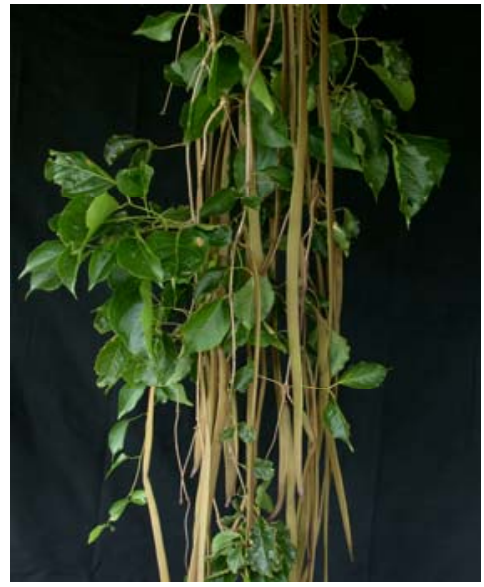

Macfadyena unguis-cati: ramo com frutos

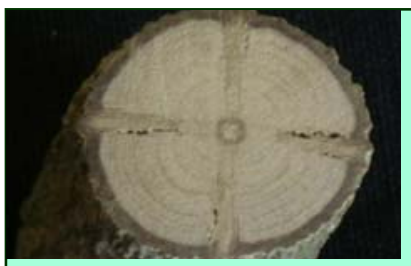

Adenocalymma marginatum: caule em corte transversal com floema em cruz

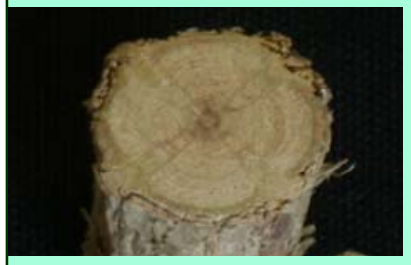

Arrabidaea conjugata: caule em corte transversal com

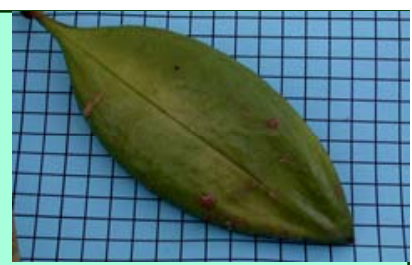

Fruto imaturo de Anemopaegma

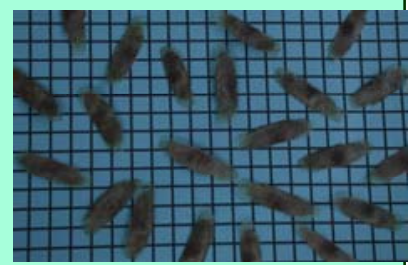

Sementes de Pyrostegia venusta 


\section{Bignoniaceae}

\section{CHAVE DE IDENTIFICAÇÃO}

1. Plantas com gavinhas ramificadas

2. Gavinhas trífidas com ápice modificado em disco adesivo

Glaziovia bauhinioides

2’. Gavinhas trífidas com ápice sem disco adesivo

3. Plantas com gavinhas não uncinadas

4. Caule cilíndrico ou sub-tetragonal Mansoa difficilis

4'. Caule hexagonal

5. Gavinhas com ramificações de $1^{\mathrm{a}}$ e e $2^{\mathrm{a}}$. ordens

Pithecoctenium crucigerum

5’. Gavinhas trífidas, ramificadas uma única vez

Pyrostegia venusta

3’. Plantas com gavinhas uncinadas

6. Folíolos glabros; pseudoestípulas ovadas Macfadyena unguis-cati

6’. Folíolos com face inferior pubescente; pseudoestípulas linear-lanceoladas Macfadyena mollis

1 '. Plantas com gavinhas simples

7. Caule anguloso

8. Ramos hexagonais Amphilophium paniculatum

8'. Ramos tetragonais Clytostoma sciuripabulum

7’. Caule cilíndrico

10. Caules e pecíolos jovens com tricomas glandulares em grande quantidade. Arrabidaea pulchra 10’. Caules glabros ou com tricomas tectores (não glandulares)

11. Pseudoestípulas foliáceas Anemopaegma chamberlaynii

11’. Pseudoestípulas, quando presentes, não foliáceas

12. Folíolos com base assimétrica

13. Folíolos com pontuações lepidotas na face abaxial Stizophyllum perforatum

13’. Folíolos sem pontuações lepidotas Lundia obliqua

12’. Folíolos com base simétrica

14. Folhas com pecíolo menor que $1,5 \mathrm{~cm}$ Arrabidaea florida

$14^{\prime}$. Folhas com pecíolo sempre maior que $2,5 \mathrm{~cm}$

15. Folíolos com domácias Tynanthus micranthus 15’. Folíolos sem domácias

16. Folíolos lanceolados, membranáceo-papiráceos, face superior opaca Adenocalymma paulistarum

16’. Folíolos ovados, cartáceo-coriáceos, face superior lustrosa

17. Margem dos folíolos levemente revoluta, cartilaginosa, que se torna branca depois de seca

Adenocalymma marginatum 17. Folíolos sem as características acima Arrabidaea conjugata 


\section{Bignoniaceae}

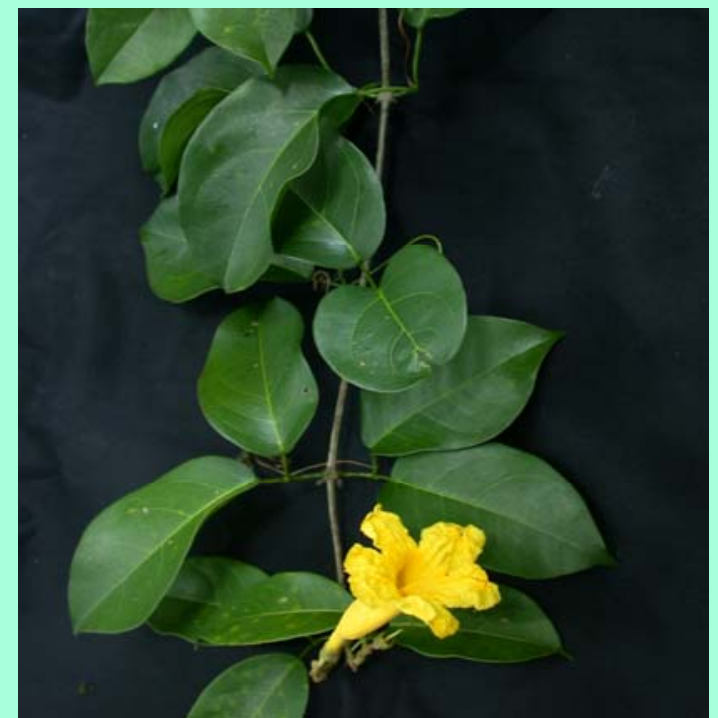

Adenocalymma marginatum (Cham.) DC.

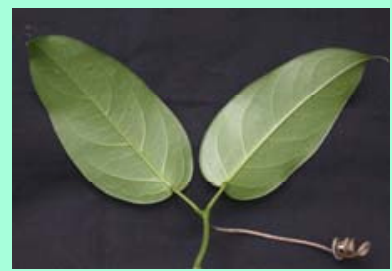

Folha: face inferior

\section{DICA DE CAMPO}

Esta espécie difere da outra do gênero que ocorre na área por apresentar folíolos coriáceos. Quando seca é facilmente reconhecida por apresentar a margem dos folíolos branca. Vegetativamente pode ser confundida com Arrabidaea conjugata, mas esta última apresenta os folíolos ondulados e a margem não é revoluta.

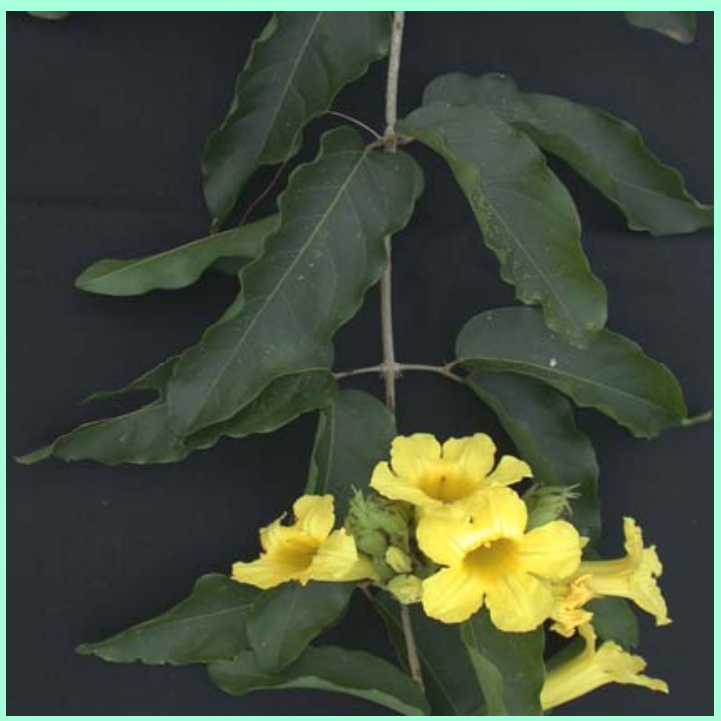

Adenocalymma paulistarum

Bureau \& K. Schum.

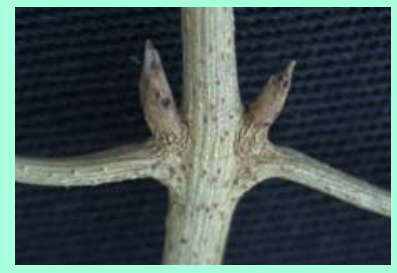

Pseudoestípulas

\section{DICA DE CAMPO}

Difere da outra espécie do gênero que ocorre na área por apresentar folíolos papiráceos e margem não revoluta. 


\section{Bignoniaceae}

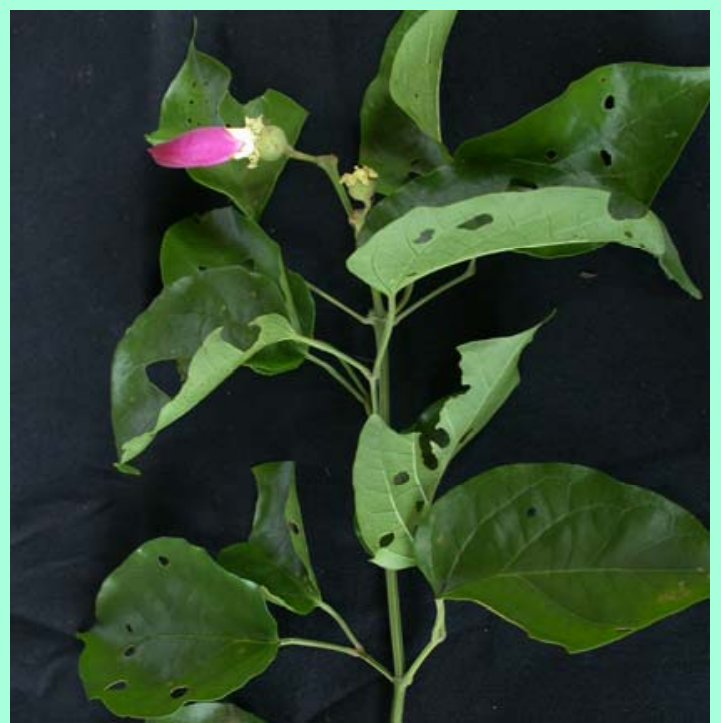

Amphilophium paniculatum (L.) Kunth

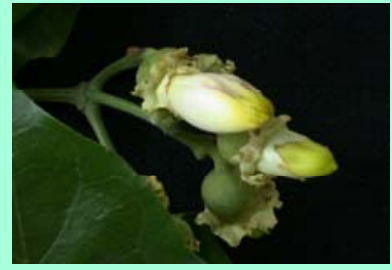

Botões florais: cálice duplo

\section{DICA DE CAMPO}

Única espécie da família, dentre as encontradas na área de estudo, que apresenta, ao mesmo tempo, gavinha simples e caule hexagonal.

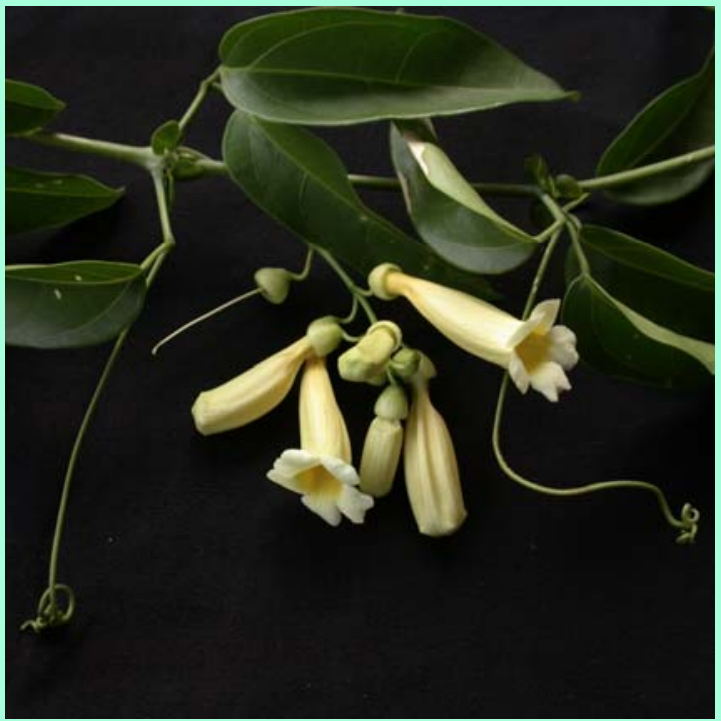

Anemopaegma chamberlaynii (Sims) Bureau \& K. Schum.

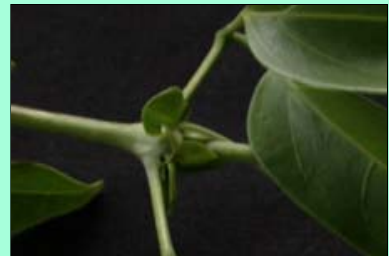

Pseudoestípulas foliáceas

\section{DICA DE CAMPO}

Dentre as espécies da família encontradas na área de estudo, é a única que apresenta pseudoestípulas foliáceas. 


\section{Bignoniaceae}

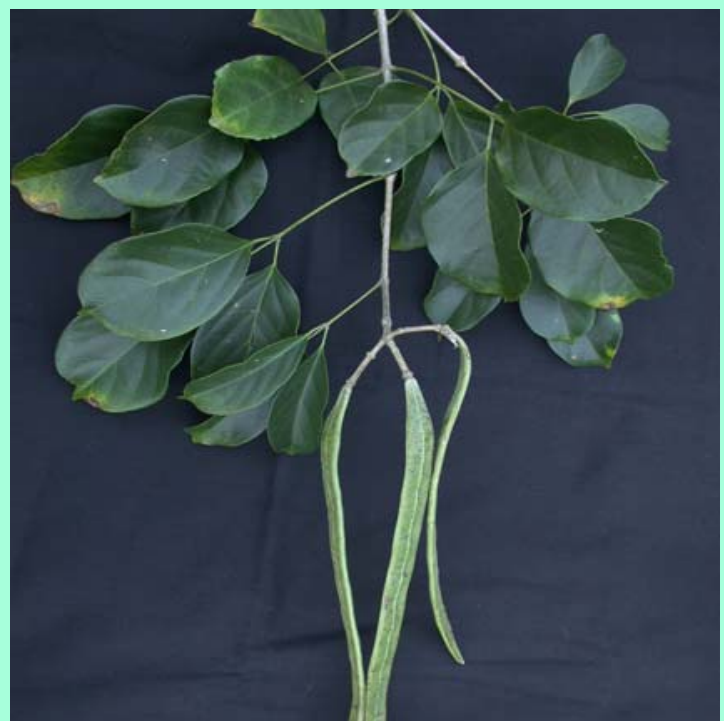

Arrabidaea conjugata (Vell.) Mart.

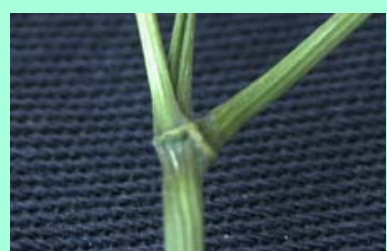

Cicatriz entre os peciólulos

\section{DICA DE CAMPO}

Espécie muito abundante nas parcelas. Vegetativamente pode ser confundida com Adenocalymma marginatum, mas suas pseudoestípulas são inconspícuas e os folíolos são bulados. Estes últimos, quando secos, não apresentam margem branca.

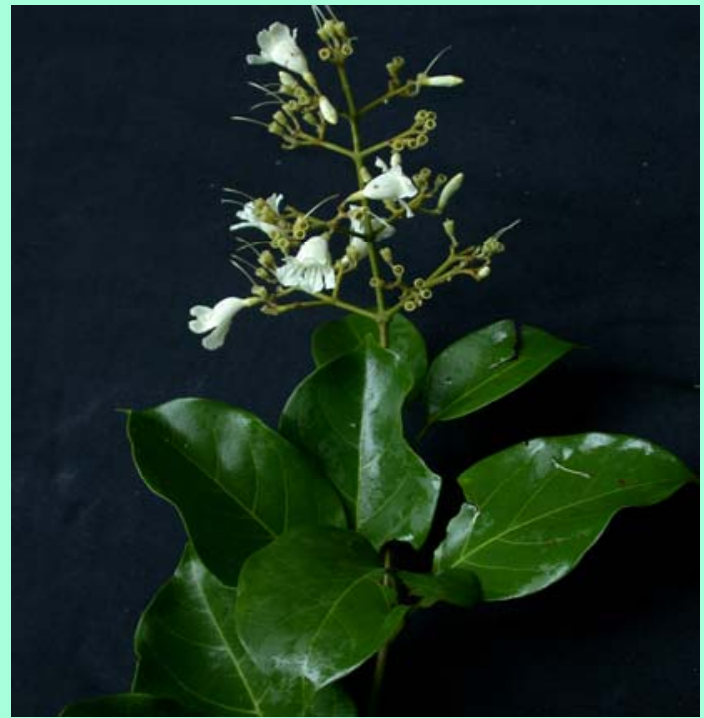

Arrabidaea florida A. DC.

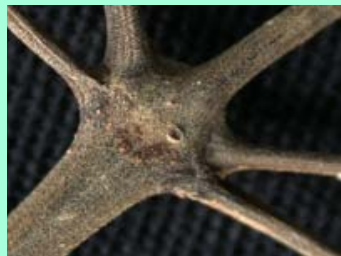

Região interpeciolar: campo de glândulas

\section{DICA DE CAMPO}

Esta espécie apresenta pecíolo sempre menor que $1,5 \mathrm{~cm}$. Dentre todas as Bignoniaceae amostradas para a área é a única que apresenta flores brancas. 


\section{Bignoniaceae}

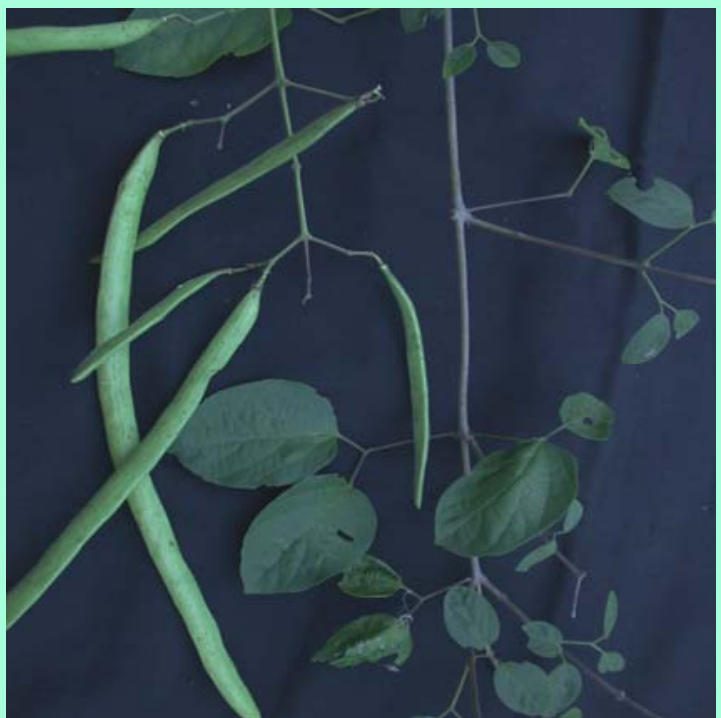

Arrabidaea pulchra (Cham.) Sandwith

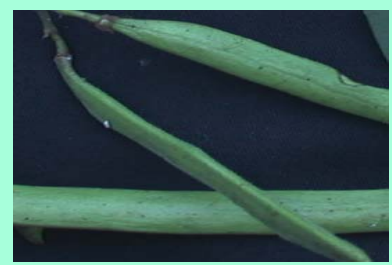

Detalhe dos frutos

\section{DICA DE CAMPO}

Planta com grande quantidade de tricomas glandulares nos caules e pecíolos jovens, tornando-os viscosos ao toque.

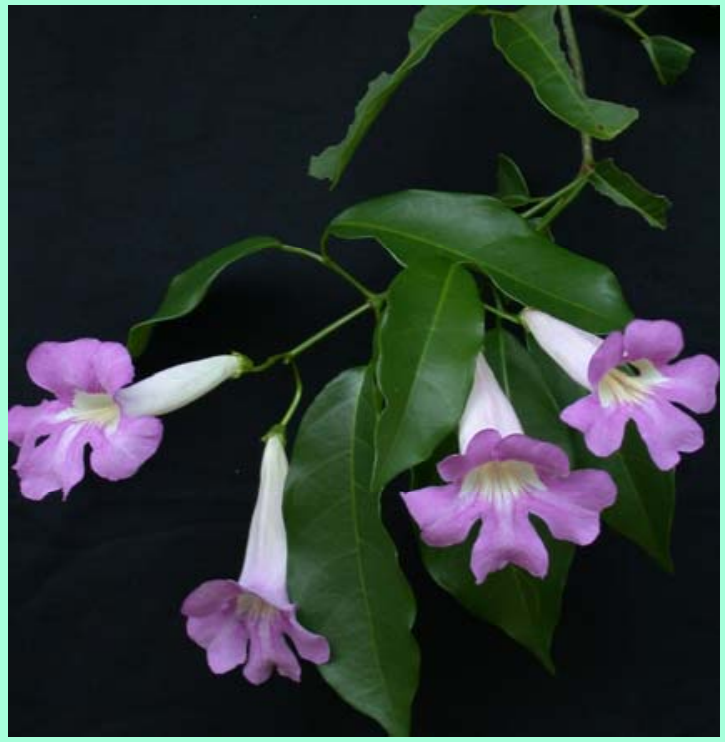

Clytostoma sciuripabulum Bureau \& K. Schum.

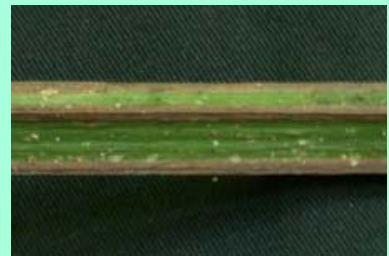

Caule tetragonal

\section{DICA DE CAMPO}

Espécie facilmente reconhecível no campo por apresentar caule conspicuamente tetragonal e gavinha simples. 


\section{Bignoniaceae}
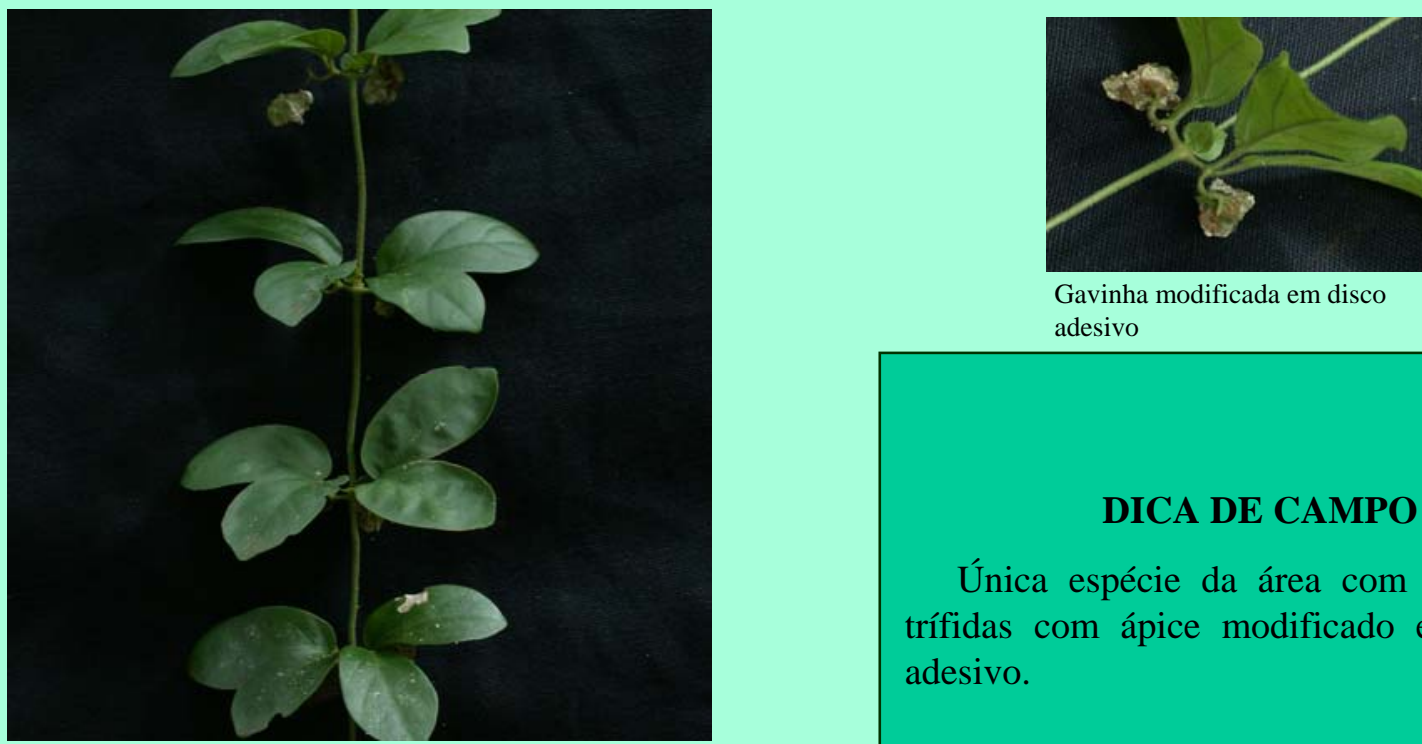

Gavinha modificada em disco adesivo

Glaziovia bauhinioides Bureau ex Baill.

\section{DICA DE CAMPO}

Única espécie da área com gavinhas trífidas com ápice modificado em disco adesivo.

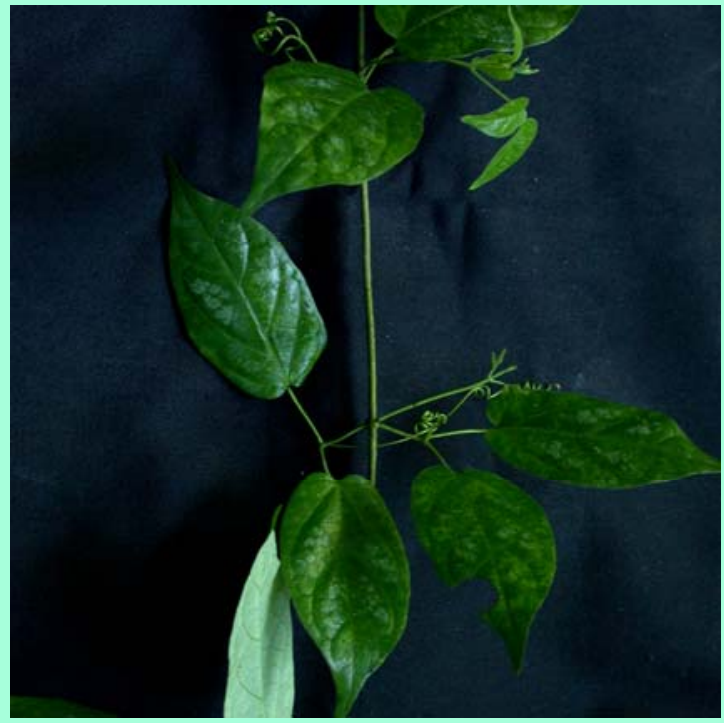

Lundia obliqua Sonder

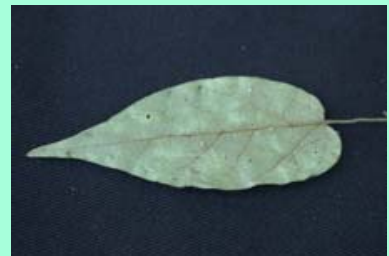

Folíolo com base assimétrica

\section{DICA DE CAMPO}

A espécie apresenta folíolos muito parecidos com os de Stizophyllum perforatum, sendo facilmente diferenciados por não apresentarem pontuações lepidotas na face abaxial. Além disso, o caule não é fistuloso como em S. perforatum. 


\section{Bignoniaceae}

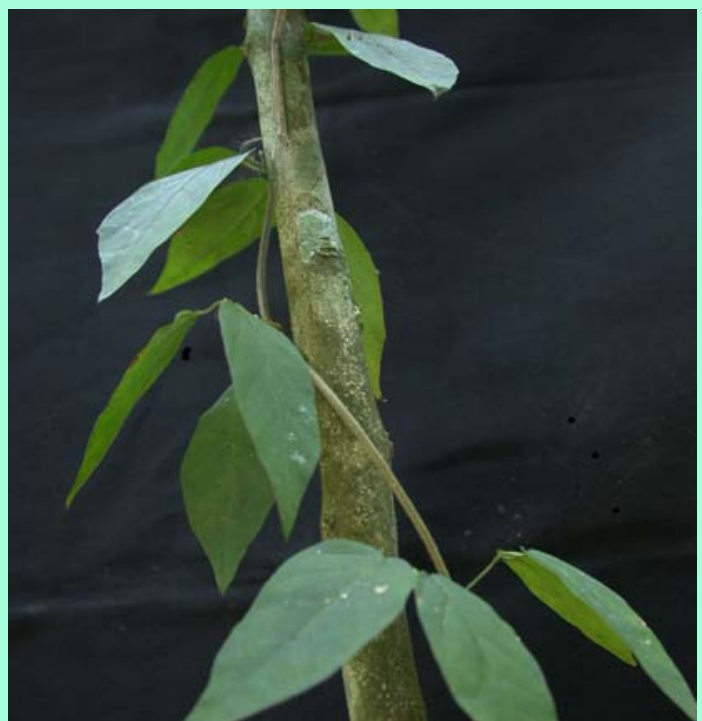

Macfadyena mollis (Sond.) Seem.

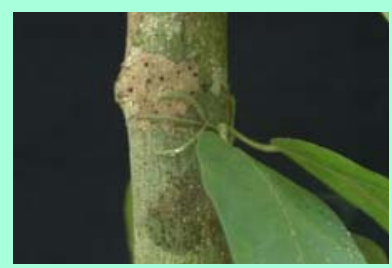

Gavinha uncinada

\section{DICA DE CAMPO}

Dentre as espécies com gavinhas uncinadas, é a única com folíolos pubescentes e pseudoestípulas linearlanceoladas.

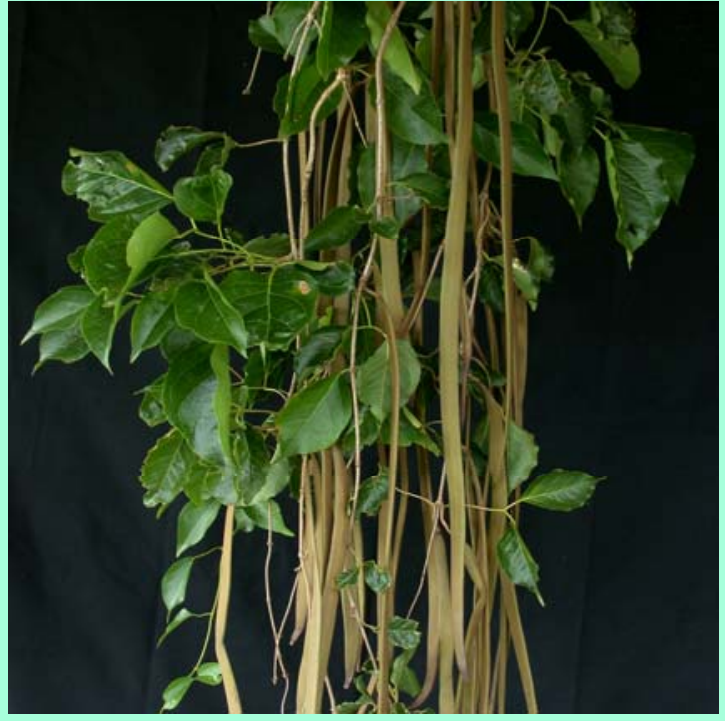

Macfadyena unguis-cati (L.) A.H. Gentry

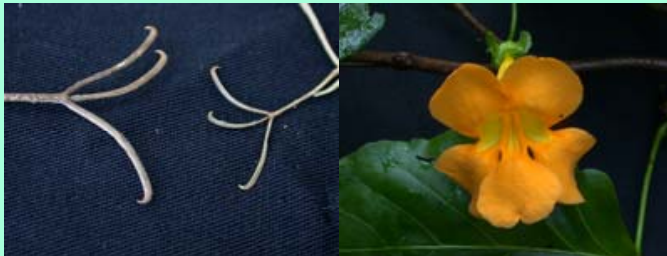

Gavinhas uncinadas

Flor

\section{DICA DE CAMPO}

Esta é uma das espécies conhecidas popularmente por unha-de-gato, pois apresenta gavinha trífida e uncinada. Difere da outra espécie do gênero por apresentar folíolos glabros e pseudoestípulas ovadas. 


\section{Bignoniaceae}

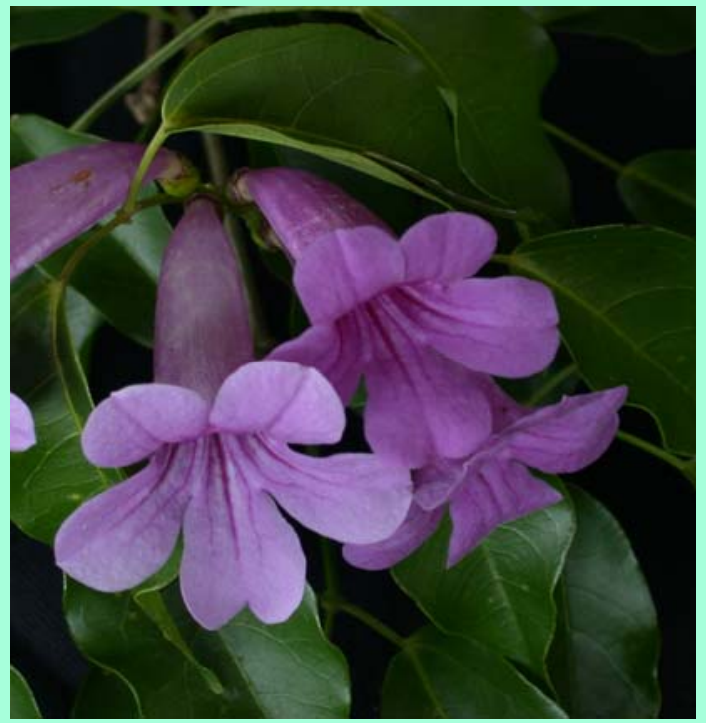

Mansoa difficilis (Cham.) Bureau \& K. Schum.

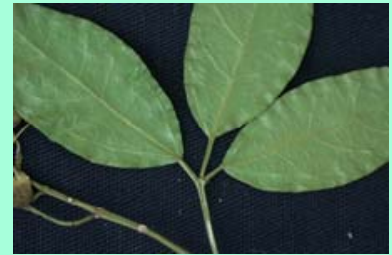

Folíolos 3-nervados

\section{DICA DE CAMPO}

Planta caracterizada por apresentar gavinha trífida, caule cilíndrico ou subtetragonal e folíolos 3-nervados.

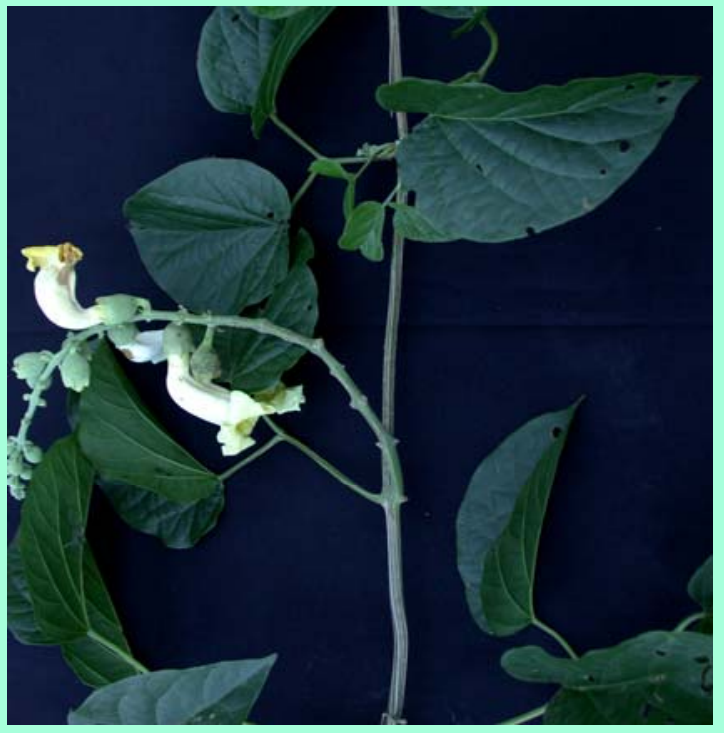

Pithecoctenium crucigerum (L.) A.H. Gentry

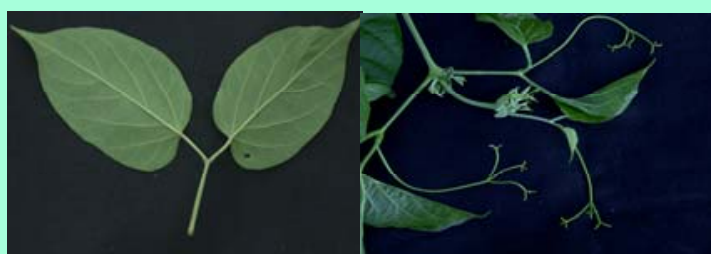

Folha: face inferior

Gavinhas 2 vezes ramificadas

\section{DICA DE CAMPO}

Esta espécie é mais comum em borda de mata, sendo encontrada apenas uma vez nas parcelas. É facilmente reconhecida por apresentar gavinha 2 vezes ramificada (com ramificações de primeira e segunda ordens) e caule hexagonal. 


\section{Bignoniaceae}

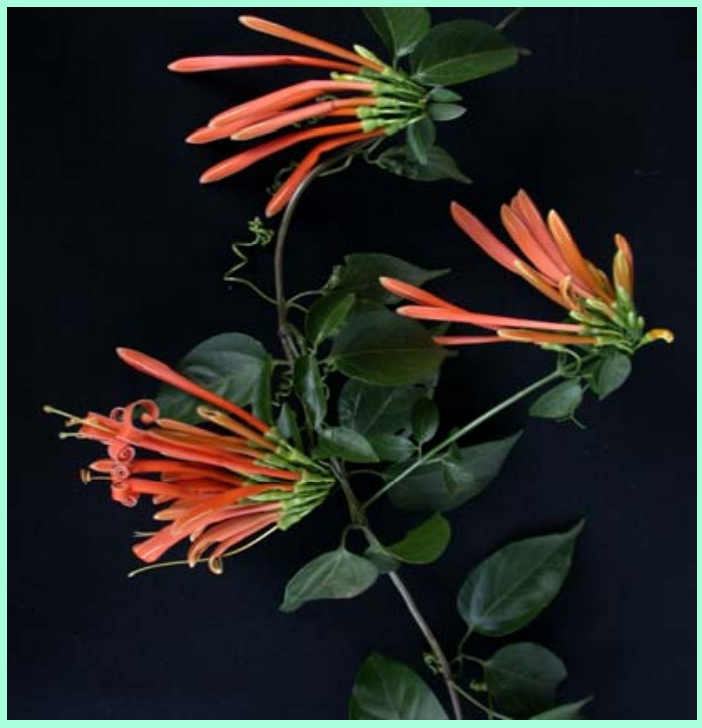

Pyrostegia venusta (Ker Gawl.) Miers

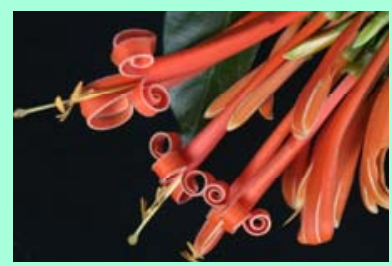

Flores

\section{DICA DE CAMPO}

Esta espécie é muito freqüente na área de estudo. Apresenta ramos hexagonais, glândulas impressas na face inferior dos folíolos e gavinhas trífidas.

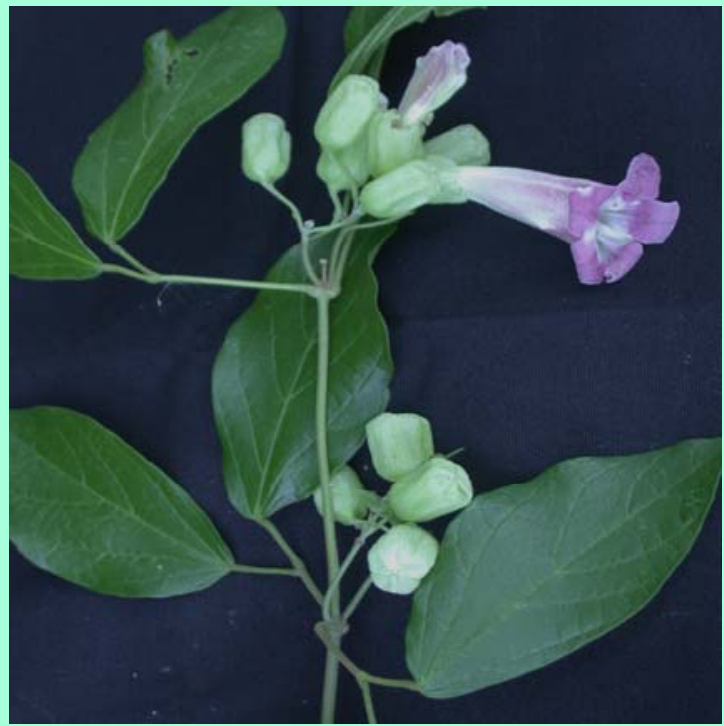

Stizophyllum perforatum (Cham.) Miers

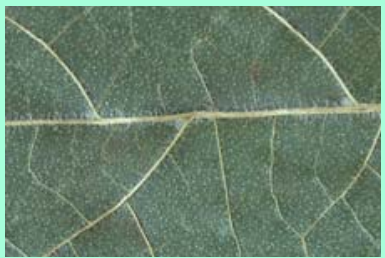

Pontuações lepidotas

\section{DICA DE CAMPO}

Liana presente apenas em grandes clareiras e bordas da mata.

Os folíolos apresentam face abaxial com pontuações lepidotas e são assimétricos. O caule é fistuloso. 


\section{Bignoniaceae}

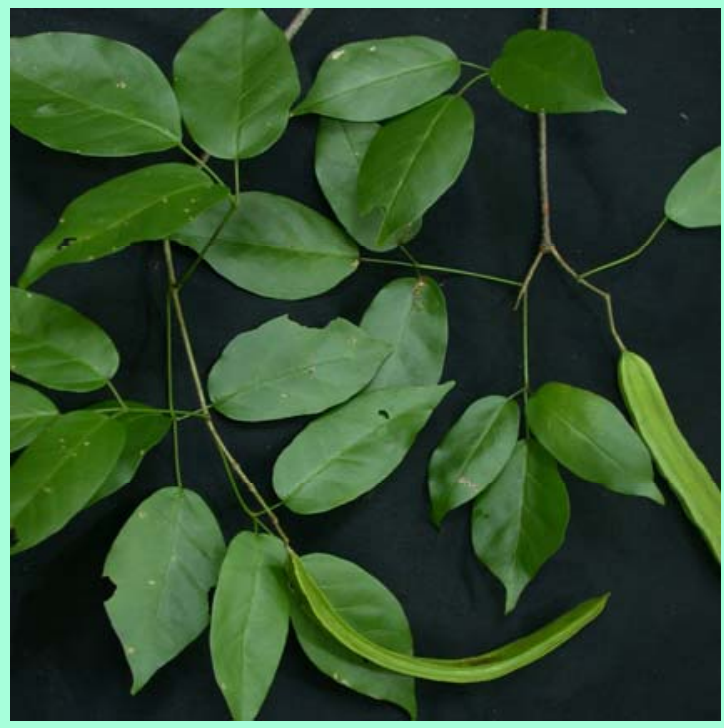

Tynanthus micranthus Corr. Méllo ex K. Schum.

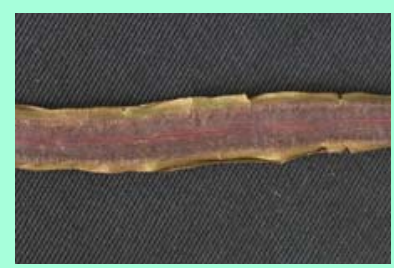

Detalhe: fruto alado

\section{DICA DE CAMPO}

Planta com pecíolo completamente glabro e limbo com tricomas apenas nas domácias.
Família neotropical representada por cerca de 1.500 espécies, distribuídas por 100 gêneros. Em geral são adaptadas às condições áridas, mas também existem lianas e epífitas em florestas úmidas. Há o registro de uma única espécie de liana na área estudada, Pereskia aculeata.

Em geral são epífitas, arbustos ou árvores, raramente lianas. O caule apresenta tufos de espinhos que ficam reunidos em estruturas denominadas aréolas. As folhas, em geral, são reduzidas ou ausentes (são conspícuas em Pereskia e Quiabentia). Apresenta flores bissexuadas, com muitas tépalas e estames; ovário ínfero com um estilete e de um a muitos estigmas. O fruto é geralmente uma baga com numerosas sementes.

\section{Cactaceae}

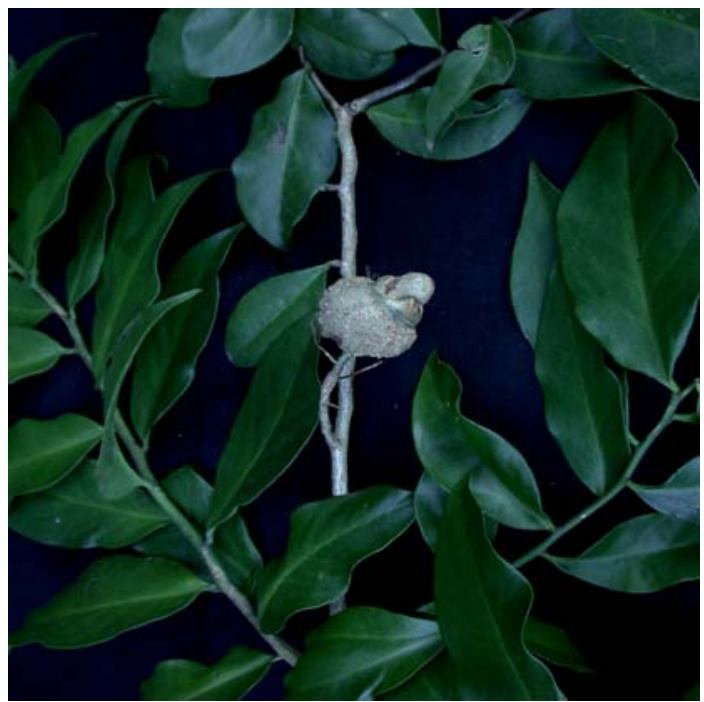

Pereskia aculeata Mill.

\section{DICA DE CAMPO}

Esta planta pode ser diferenciada das demais espécies de lianas da área por apresentar espinhos no caule, folhas com consistência carnosa e apenas a nervura central bem evidente. 


\section{Dilleniaceae}

Família com aproximadamente 300 espécies, distribuídas por 12 gêneros. Apresenta distribuição pantropical e ocorre com maior freqüência nos Neotrópicos. No trecho da Estação onde o estudo foi desenvolvido encontrou-se duas espécies.

A maioria das espécies são lenhosas com hábito lianescente, mas também podem ser encontrados arbustos, árvores e ervas. Algumas lianas são popularmente conhecidas como cipós-d’água, pois o tronco fornece água potável.

Família de fácil reconhecimento no campo, apresentando tronco geralmente de cor alaranjada que desprende lâminas papiráceas. Em corte transversal apresenta anéis concêntricos estriados. As folhas são simples, geralmente alternas espiraladas, com margem, em geral, serrilhada e nervuras secundárias apiculadas, proeminentes e numerosas. As flores são actinomorfas, com cálice persistente e pétalas caducas, caindo logo após a abertura da flor.
Flores de Davilla rugosa

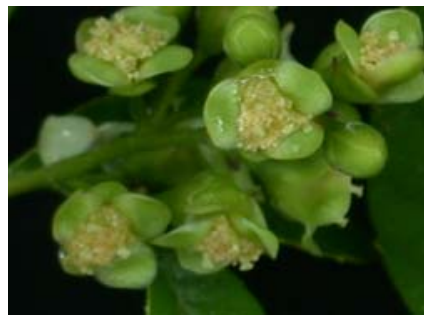

\section{CHAVE DE IDENTIFICAÇÃO}

1. Folhas elípticas ou obovadas ... Davilla rugosa

$1^{\prime}$. Folhas oblanceoladas ............. Doliocarpus sp.

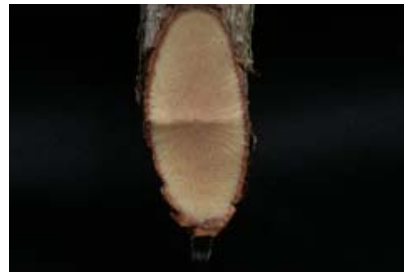

Caule de Davilla rugosa em corte oblíquo

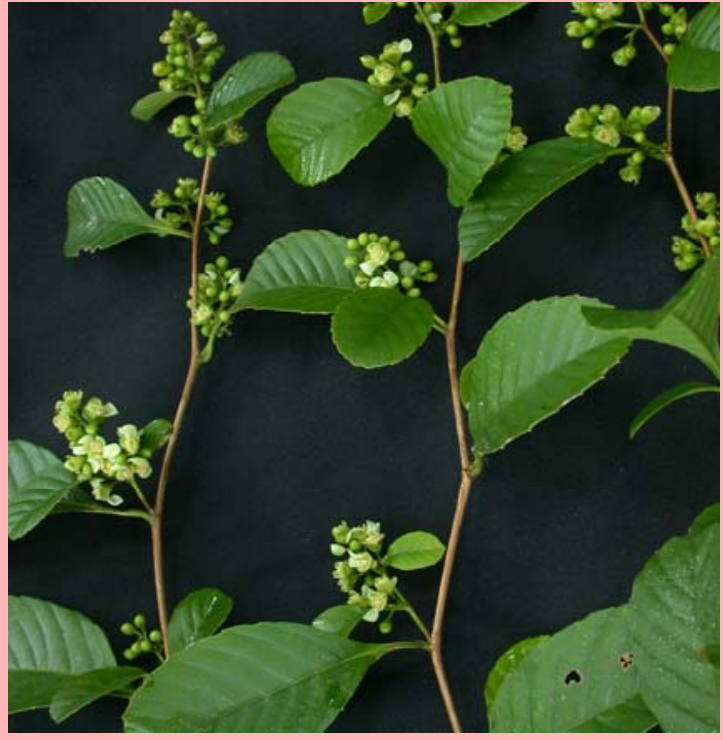

Davilla rugosa Poir.

\section{DICA DE CAMPO}

Planta com folhas variando de elípticas a obovadas e face abaxial muito áspera ao toque.

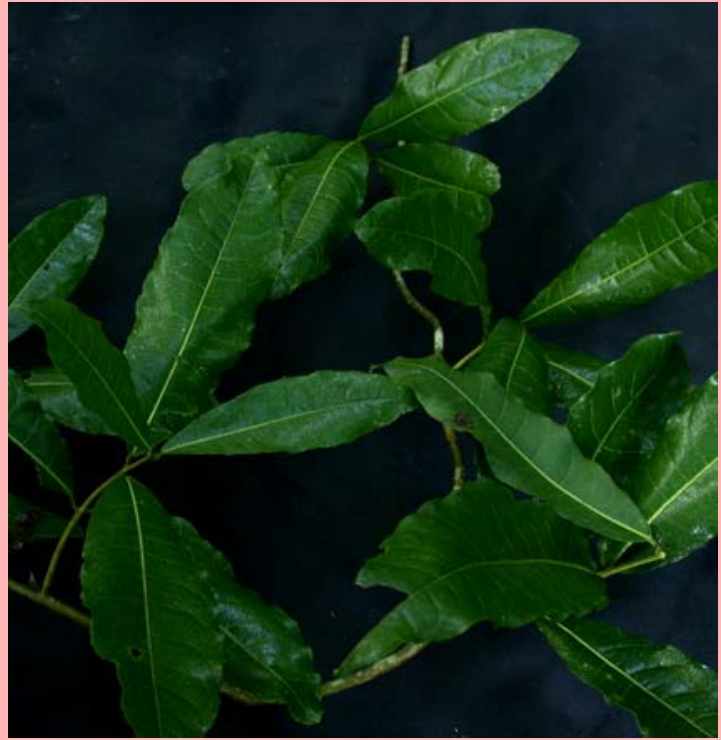

Doliocarpus sp.

\section{DICA DE CAMPO}

Pode ser diferenciada da outra espécie por apresentar folhas oblanceoladas, mas também ásperas ao toque. 


\section{Hippocrateaceae}

Esta família conta com 12 gêneros e cerca de 120 espécies, distribuídas pela região neotropical, sendo a bacia amazônica o centro de diversidade para o grupo. $\mathrm{Na}$ área de estudo foram encontradas apenas 2 espécies.

São plantas lenhosas, podendo ser arbustos, árvores ou lianas. As folhas são opostas, com estípulas pequenas e caducas, raramente persistentes. As flores são pequenas, com coloração variando de amarela a esverdeada, pentâmeras, com corola dialipétala; apresenta disco nectarífero. O androceu é formado por 3 (5) estames e o ovário é súpero. Fruto drupáceo, baciforme ou capsular, com sementes freqüentemente aladas.

Esta família foi recentemente, a partir de estudos moleculares, incluída em Celastraceae.

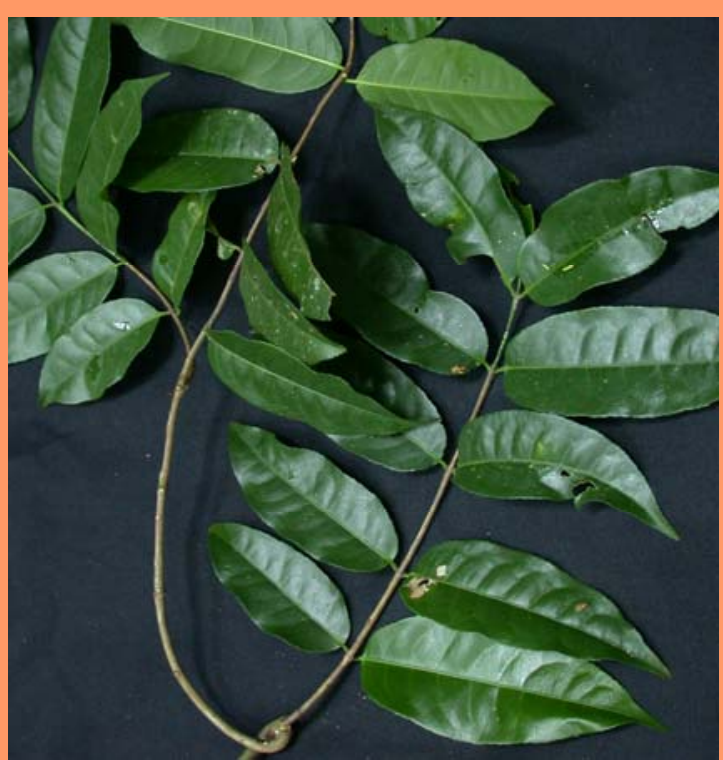

Anthodon decussatum Ruiz \& Pav.

\section{DICA DE CAMPO}

Difere da outra espécie da família por apresentar folhas membranáceas, com ápice acuminado e face superior lustrosa.

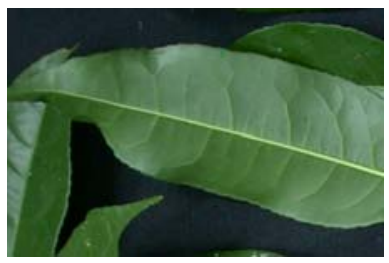

Folha de Anthodon decussatum: face abaxial

\section{CHAVE DE IDENTIFICAÇÃO}

1. Folhas membranáceas, com ápice acuminado e face superior lustrosa ....... Anthodon decussatum

1'. Folhas cartáceas, com ápice agudo e face superior opaca Hippocratea volubilis

Caule modificado em gancho de Hippocratea volubilis

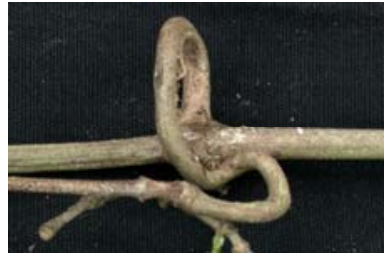

Hippocratea volubilis L.

\section{DICA DE CAMPO}

Planta com folhas cartáceas, de ápice agudo e face superior opaca. 


\section{Leguminosae}

Esta família é uma das maiores, dentre as Angiospermas, com cerca de 18.000 espécies distribuídas por 642 gêneros. Apresenta distribuição cosmopolita, estando representada principalmente nas regiões tropicais e subtropicais.

São plantas de hábito muito variado, podendo existir árvores, arbustos, ervas ou lianas, as quais podem ser herbáceas ou lenhosas. Podem viver nos mais variados ambientes, em diferentes latitudes e altitudes. As folhas são alternas e compostas, com estípulas e estipelas às vezes transformadas em espinhos; com pulvinos na base dos pecíolos e peciólulos. Essa família é subdividida em 3 subfamílias:

Caesalpinioideae: 180 gêneros e 2.500 espécies; apresenta prefloração da corola imbricada ascendente.

Faboideae: 500 gêneros e 10.000 espécies; apresenta prefloração da corola imbricada descendente.

Mimosoideae: 60 gêneros e 3.000 espécies; apresenta prefloração valvar.

\section{CHAVE DE IDENTIFICAÇÃO}

1. Planta com folhas bicompostas

Acacia plumosa

1'. Plantas com folhas bifolioladas ou pinadas

2. Planta com folhas bifolioladas, com folíolos fundidos Bauhinia microstachya

2’. Folhas com mais de 5 folíolos

Dalbergia frutescens

\section{Leguminosae - Caesalpinioideae}

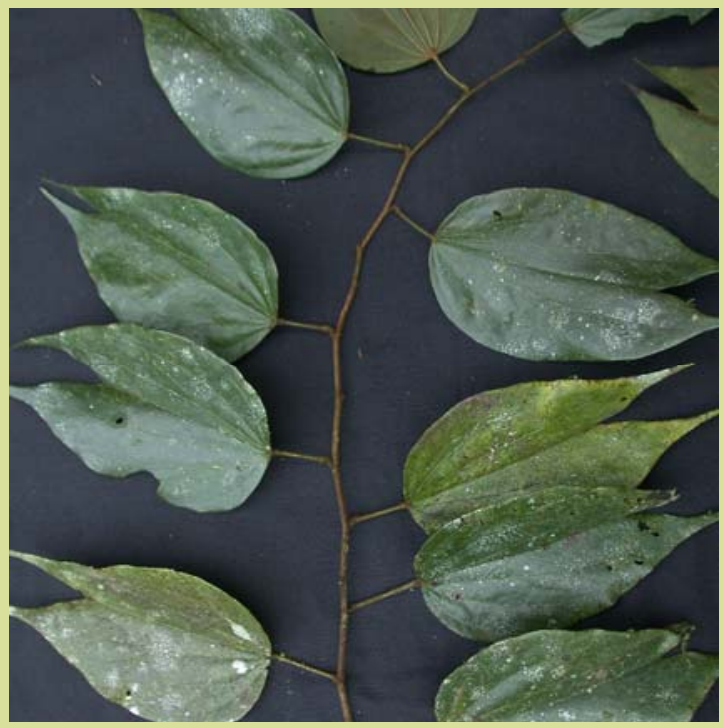

Bauhinia microstachya (Raddi) J.F. Macbr.

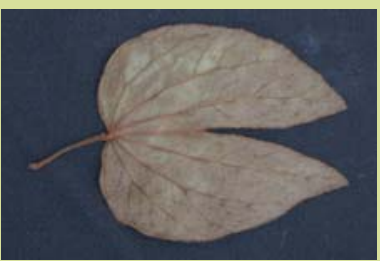

Folha: face abaxial

\section{DICA DE CAMPO}

Planta conhecida popularmente por escada de macaco. Apresenta folhas alternas e bifolioladas com folíolos fundidos. 


\section{Leguminosae - Faboideae}



Dalbergia frutescens (Vell.) Britton

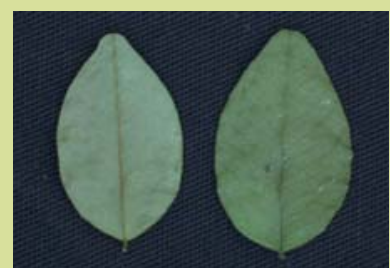

Folíolos: face abaxial e adaxial

\section{DICA DE CAMPO}

Espécie facilmente reconhecida na área por apresentar folhas pinadas.

\section{Leguminosae -Mimosoideae}

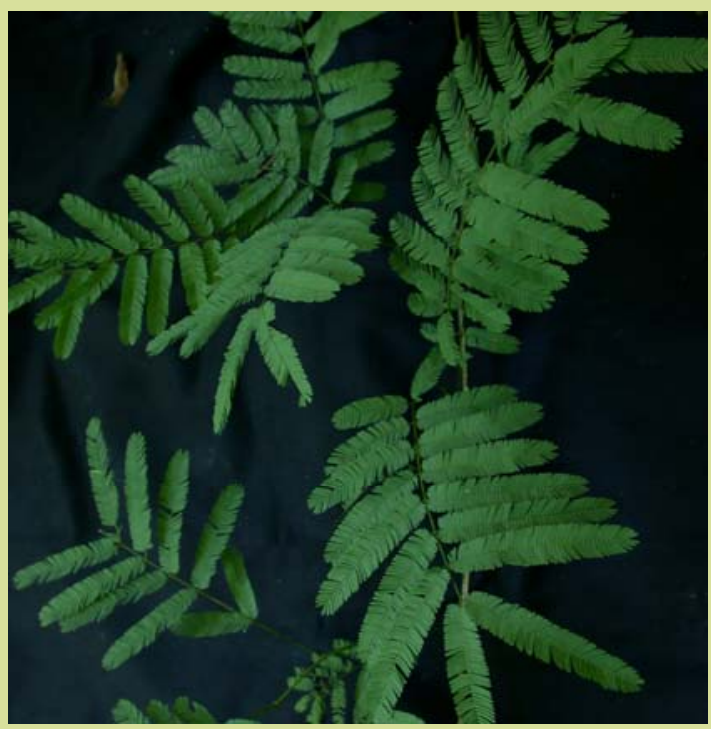

Acacia plumosa Lowe

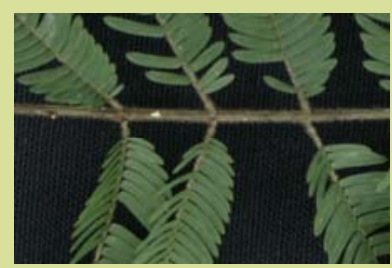

Raque foliar

\section{DICA DE CAMPO}

Esta espécie pode ser facilmente reconhecida por ser a única na área a apresentar folhas bicompostas. A raque foliar é provida de glândulas circulares. 


\section{Malpighiaceae}

distribuida pelas regiões tropicais e do mundo, principalmente no americano, onde é seu centro de de. É um grupo composto por cerca de os e 1.250 espécies, dos quais 44 gêneros nécies ocorrem nas Américas. No trecho גção florestal estudada foram encontrados os e 4 espécies de lianas.

Malpighiaceae são facilmente cidas vegetativamente por apresentarem simples, opostas, com margem inteira e s do tipo malpiguiáceo (com a forma de Apresentam, em geral, estípulas ciolares, as quais podem ser caducas nas A presença de glândulas na base das ou no peciolo é freqüente nas lianas, sendo caráter diagnóstico, pois e a única família nas na área com folhas opostas que nta esta característica. As flores são ente reconhecidas por apresentarem um par tarios em cada sépala.

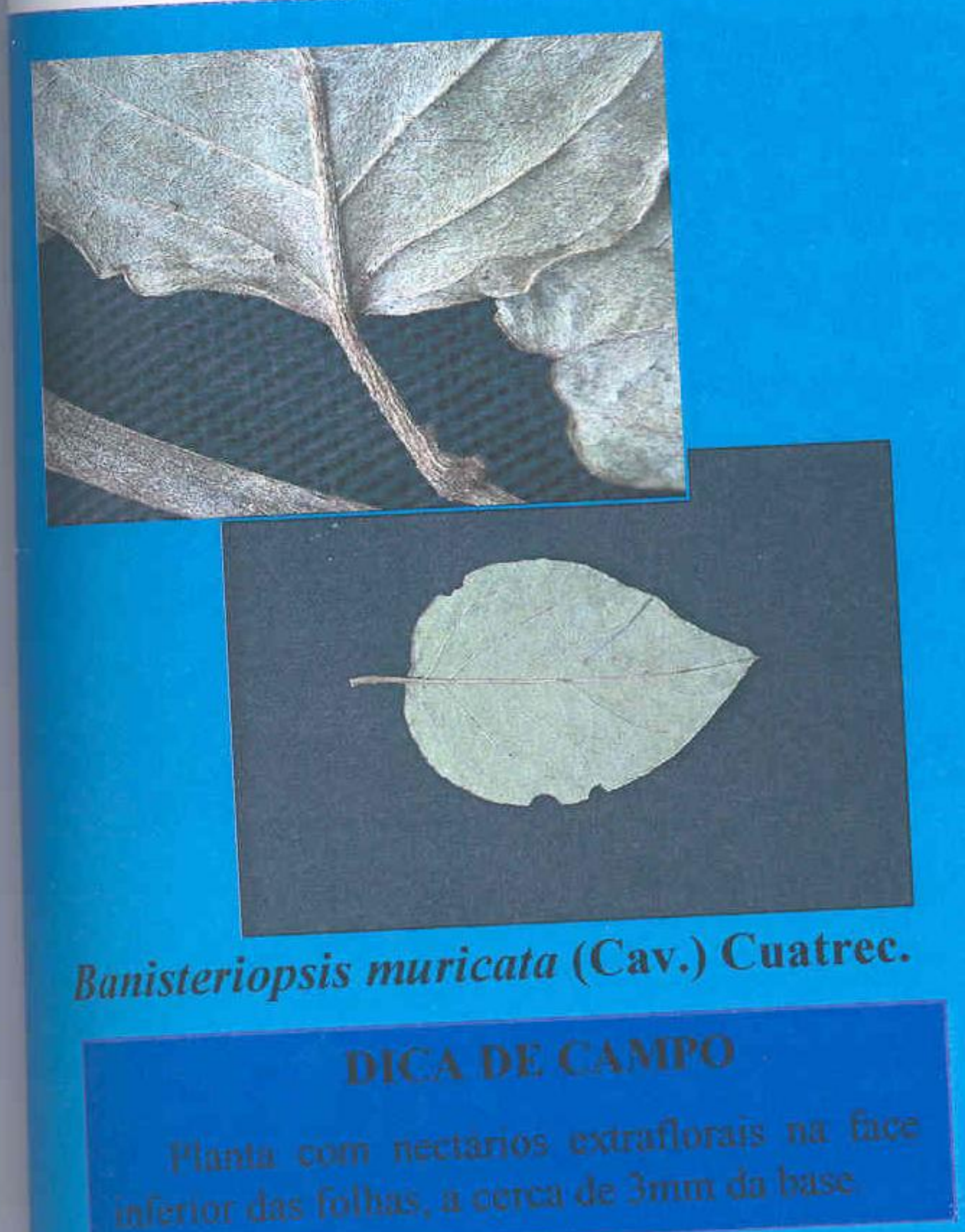

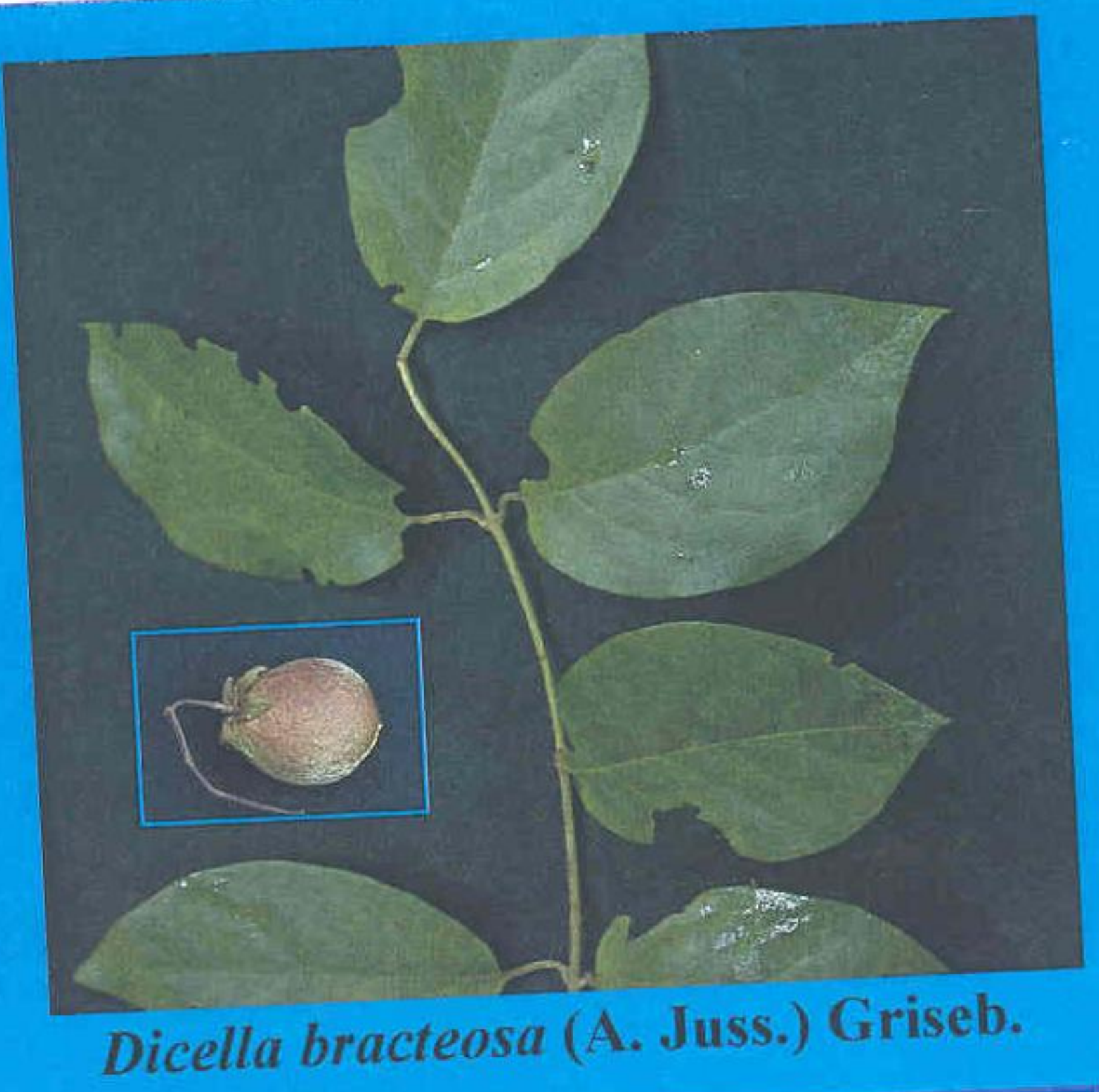

Dicella bracteosa (A. Juss.) Griseb. 


\section{Malpighiaceae}
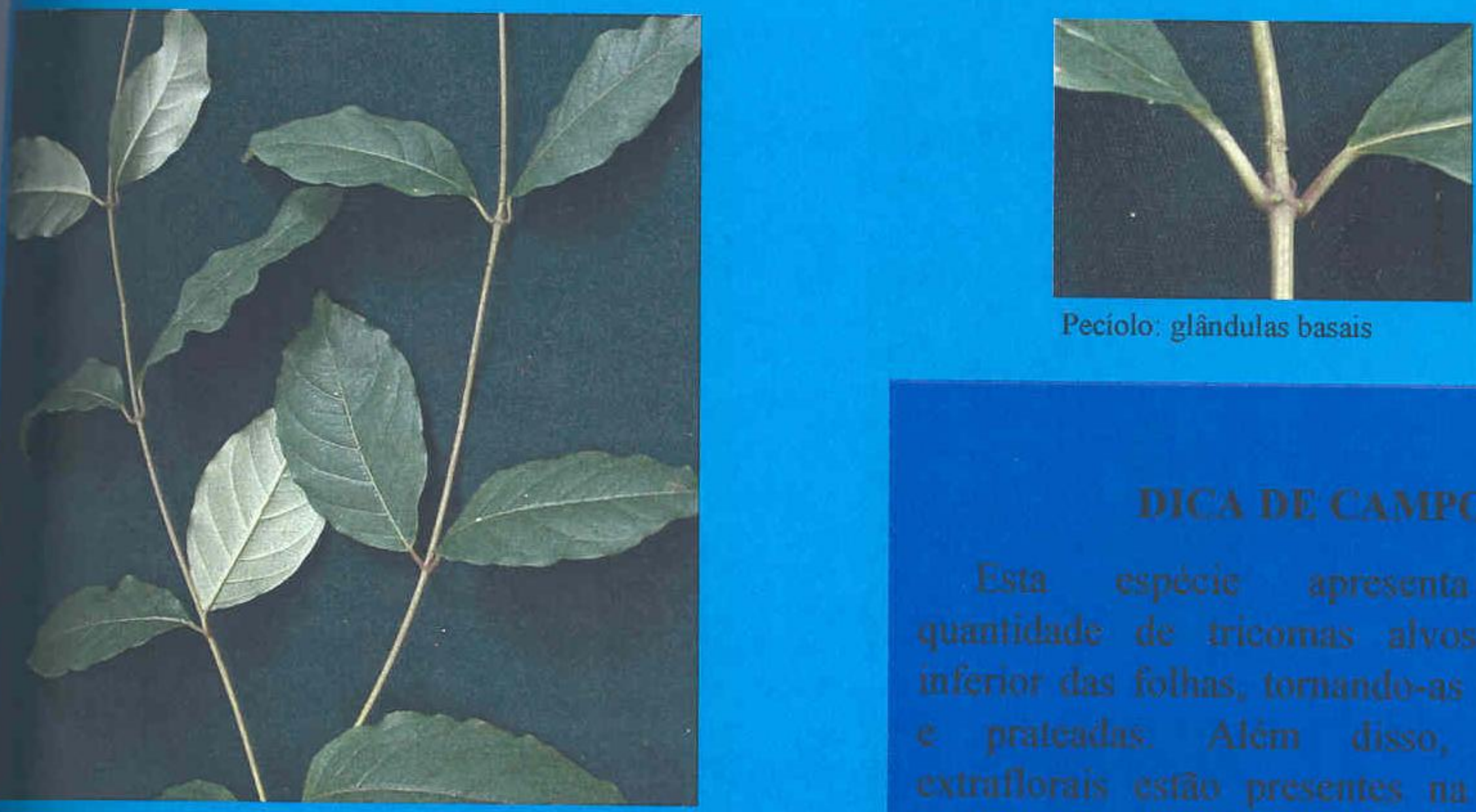

Peciolo: glândulas basais

eteropterys sp.

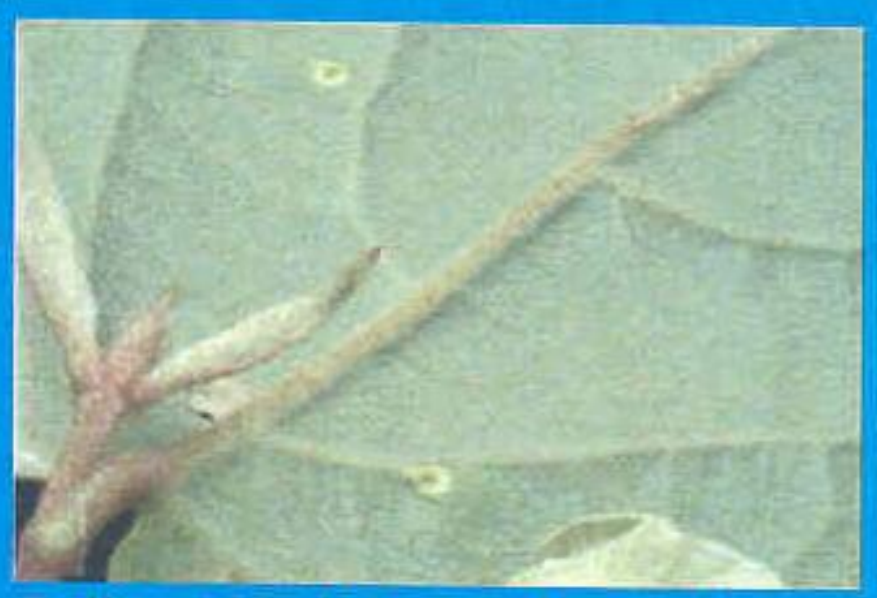

Folha: glândulas na face inferior

ascagnia cordifolia (A. Juss.) Griseb. 
Nyctaginaceae

Nyctaginaceae conta com 30 gêneros e cerca de 400 espécies com distribuição pantropical. No local estudado está representada por duas espécies de lianas, Bougainvillea glabra e Pisonia aculeata.

O hábito nesse grupo é bastante variado, existindo desde pequenas ervas até grandes árvores. As folhas são simples e as inflorescências, em geral, são cimosas. O ovário é súpero e o fruto é do tipo drupa indeiscente, às vezes envolto pela base do cálice persistente.

Nyctaginaceae é uma família de difícil reconhecimento no campo. De modo geral, suas espécies apresentam folhas opostas ou subopostas em um nó, alternando com um outro onde o caule se ramifica ou as folhas são verticiladas. As folhas geralmente são suculentas. Tanto as folhas quanto o tronco apresentam rápida oxidação quando partidos, o que deixa a parte afetada enegrecida rapidamente.

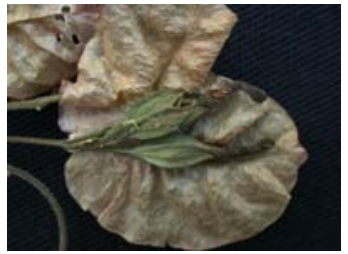

Frutos de Bougainvillea glabra
Frutos de Pisonia aculeata

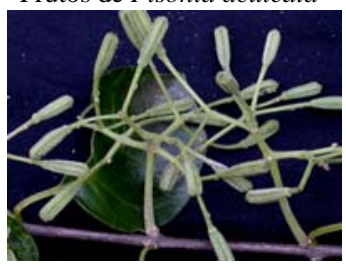

\section{CHAVE DE IDENTIFICAÇÃO}

1. Folhas com face inferior e pecíolo velutinos .... Bougainvillea glabra

$1^{\prime}$. Folhas com face inferior e pecíolo apresentando poucos tricomas esparsos

Pisonia aculeata

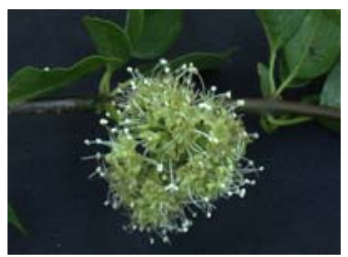

Flores de Pisonia aculeata
Caule de Pisonia aculeata

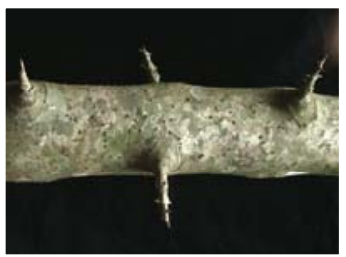

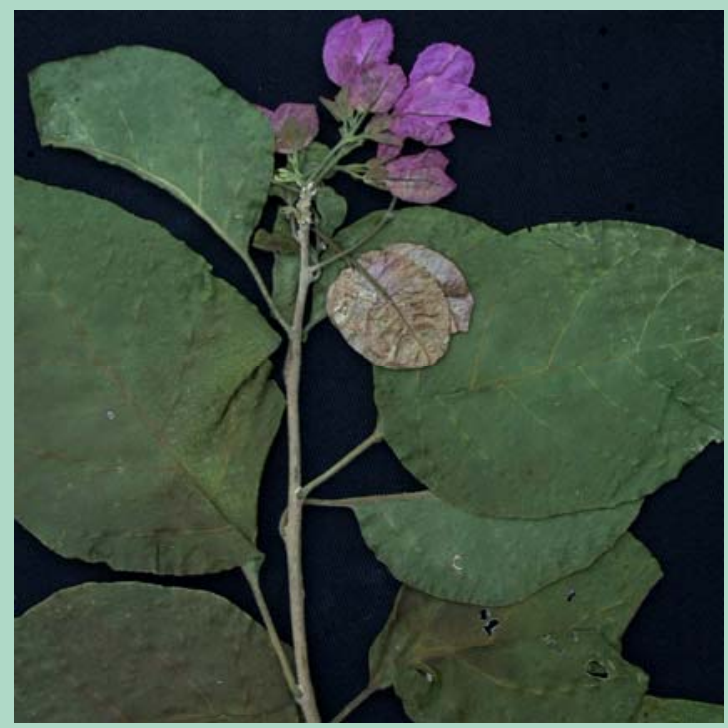

Bougainvillea glabra Choisy

\section{DICA DE CAMPO}

Planta com folhas alternas e face inferior das folhas velutina.

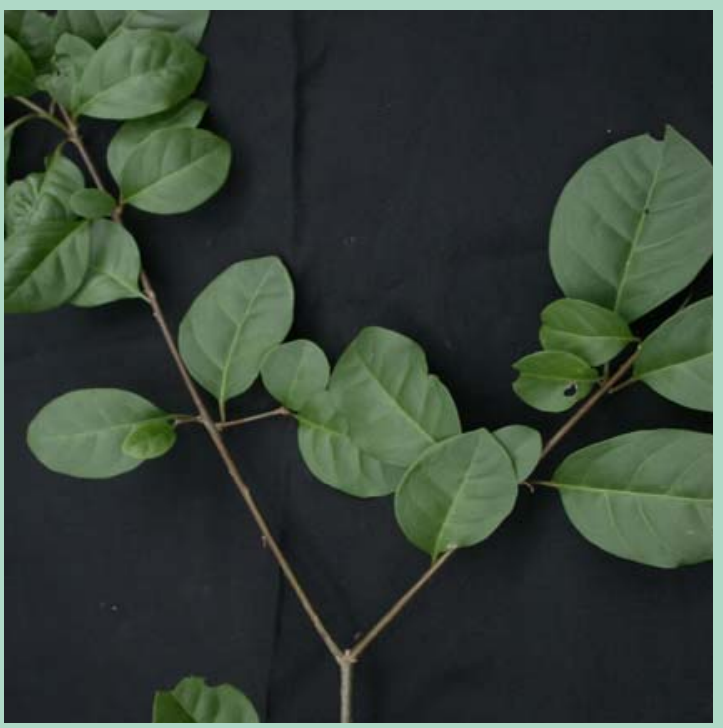

\section{Pisonia aculeata L.}

\section{DICA DE CAMPO}

Planta com folhas subopostas e face inferior das folhas com poucos tricomas esparsos. 


\section{Phytolaccaceae}

Phytolaccaceae é uma família relativamente pequena, com 17 gêneros e cerca de 80 espécies, distribuídas principalmente pela América do Sul tropical e subtropical. Foi encontrada, na área de estudo, uma única espécie com hábito lianescente, Seguieria floribunda.

São árvores, lianas, arbustos ou ervas. As folhas são simples e alternas. As flores são dióicas, monoclamídeas e com gineceu sincárpico; os frutos são bagas.

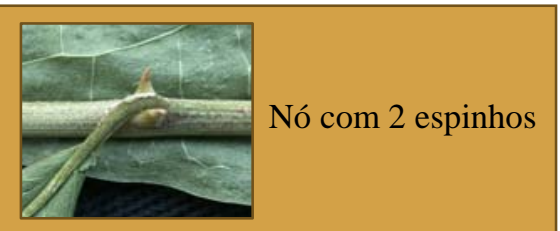

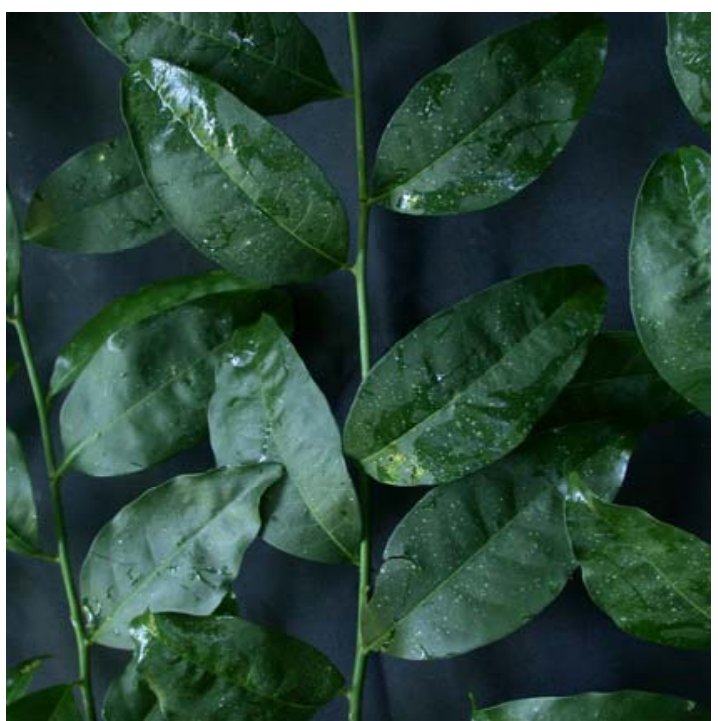

Seguieria floribunda Benth.

\section{DICA DE CAMPO}

Planta com folhas alternas e 2 espinhos pequenos e curvos na base do pecíolo. Esta espécie também pode ser encontrada com hábito arbóreo.
Família amplamente distribuída, ocorrendo em regiões temperadas, subtropicais e tropicais, compreende cerca de 50 gêneros e 900 espécies. Apresenta hábito bastante variado, desde árvores, arbustos, lianas até ervas (mais raramente).

Trata-se de um grupo com poucos representantes no Brasil. No local estudado foi encontrada apenas uma espécie, Gouania acalyphoides.

A maioria das espécies tem venação característica, marcadamente ascendente ou reta; as veias terciárias são mais ou menos paralelas e perpendiculares às secundárias.

\section{Rhamnaceae}

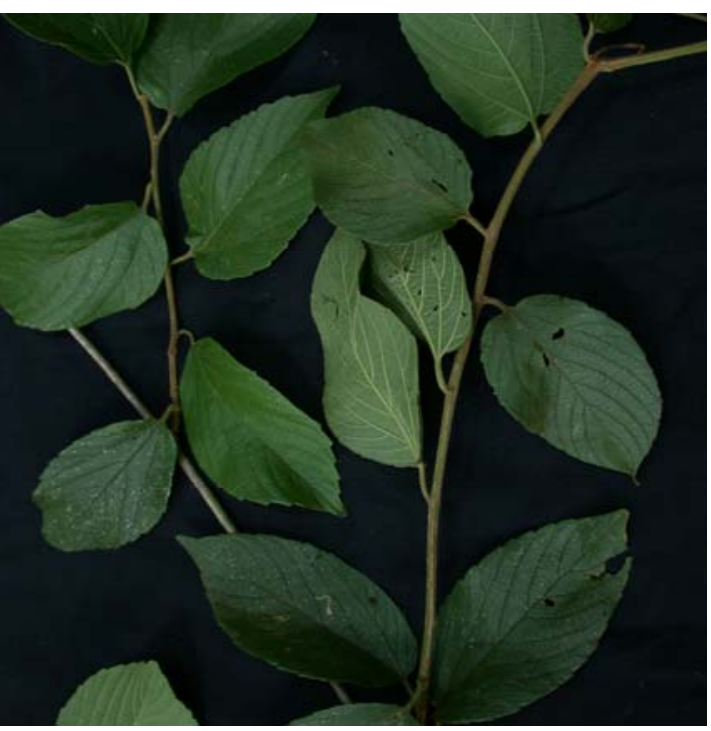

Gouania acalyphoides Reissek

\section{DICA DE CAMPO}

Dentre as espécies com folhas simples e alternas é a única com gavinha na axila das folhas. 


\section{Sapindaceae}

Família com 135 gêneros e cerca de 1.500 espécies distribuídas pelas regiões tropicais e subtropicais, com poucas espécies ocorrendo em áreas de clima temperado. No trecho estudado foram encontradas 7 espécies de lianas pertencentes ao gêneros Serjania, Thinouia e Urvillea, sendo o primeiro um dos maiores na família, em número de espécies.

São arbustos, árvores ou lianas, as quais podem ser herbáceas ou lenhosas, com folhas alternas, em geral compostas e gavinhas bífidas (nas lianas). As flores são pequenas, brancas ou amarelas, com pedicelo articulado e presença de disco nectarífero. Os frutos podem ser deiscentes ou indeiscentes, secos ou carnosos, às vezes alados, com sementes freqüentemente ariladas.

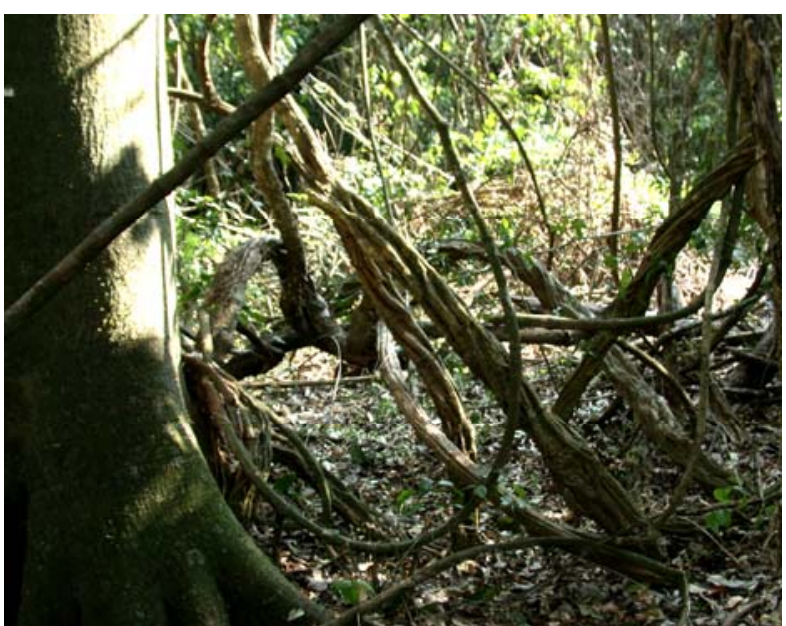

Caule de Thinouia ventricosa

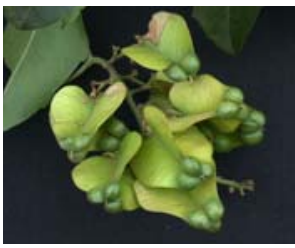

Frutos de Serjania caracasana

Flor de Serjania caracasana

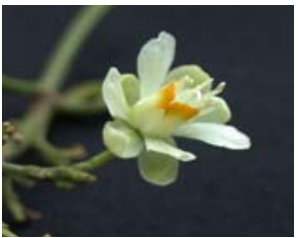

\section{CHAVE DE IDENTIFICAÇÃO}

1. Folhas 3-folioladas

2. Folíolos triplinérveos e cartáceos Thinouia ventricosa

2’. Folíolos peninérveos e membranáceos Urvillea laevis

$1^{\prime}$. Folhas 2-ternadas

3. Ramo com câmbio único .Serjania meridionalis

3.Ramo com câmbio central e supernumerários

4. Oito câmbios supernumerários, sendo o central do mesmo tamanho dos demais Serjania fuscifolia

4'. Câmbio central maior que os supernumerários, sendo o total diferente de 8

5. Caule com 5 câmbios

supernumerários agrupados 2-2-1, de forma eqüidistante .... Serjania glabrata

5'. Caule com câmbios

supernumerários não eqüidistantes

6. Estípula triangular persistente

Serjania caracasana

6'. Estípula linear caduca, deixando cicatriz semilunar..... Serjania laruotteana

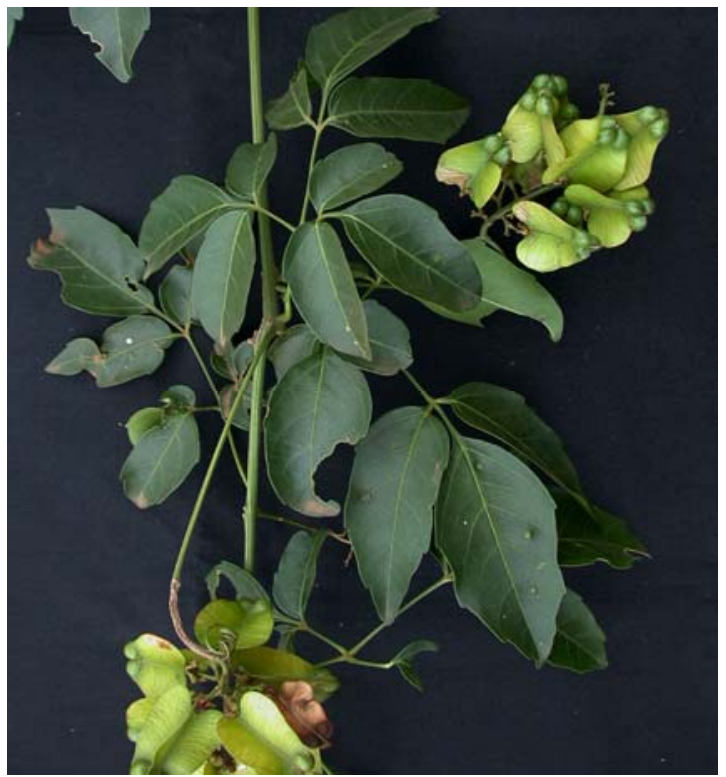

Serjania caracasana (Jacq.) Willd.
É facilmente reconhecida, pois apresenta estípula triangular persistente. 


\section{Sapindaceae}

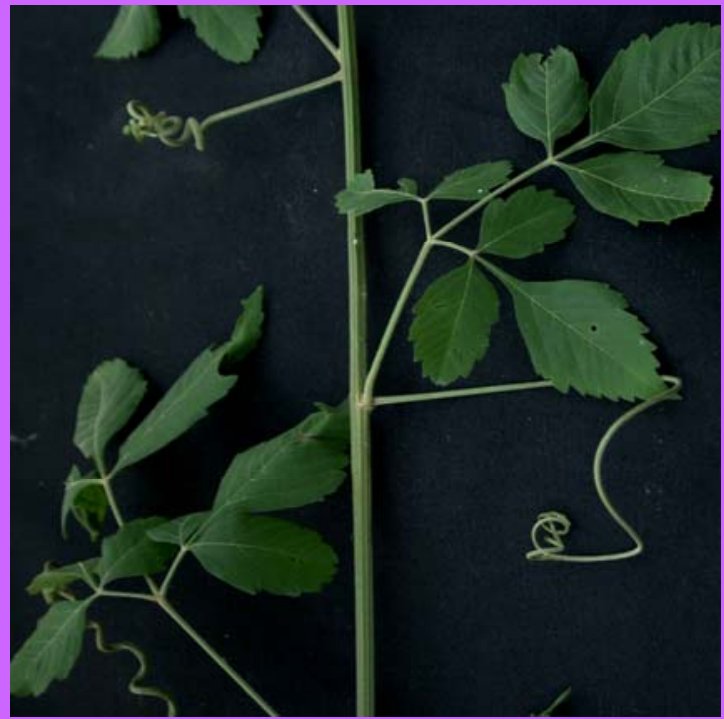

Serjania fuscifolia Radlk.

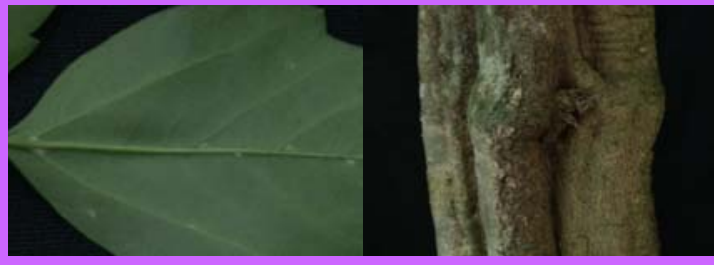

Folha: face inferior com domácias

\section{DICA DE CAMPO}

Esta espécie apresenta folíolos com ambas as faces pubérulas. É reconhecida com grande facilidade por apresentar 8 câmbios supernumerários do mesmo tamanho que o central.

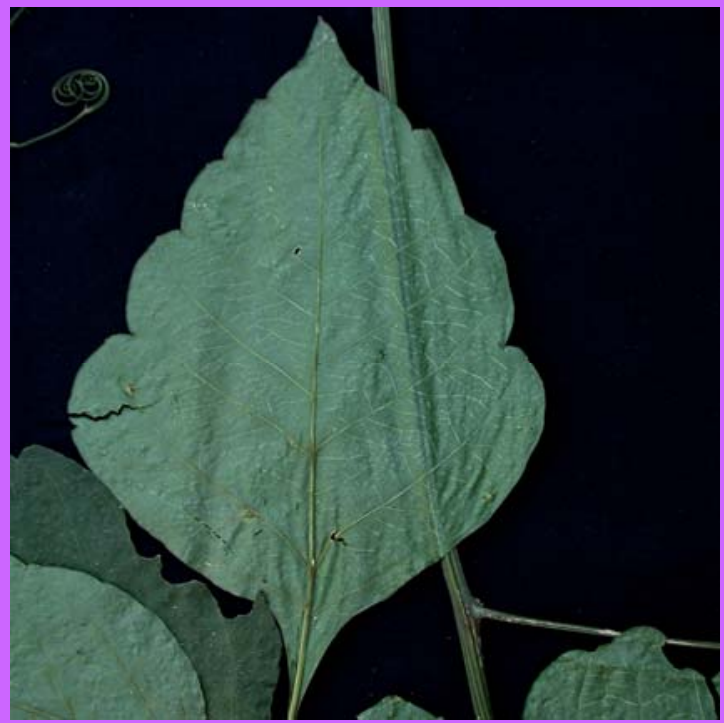

Serjania glabrata Kunth

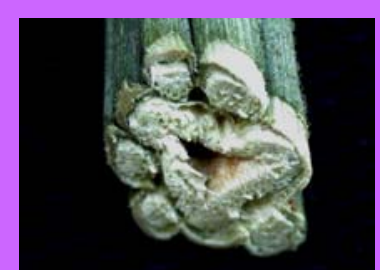

Caule em corte transversal: câmbios

\section{DICA DE CAMPO}

Esta espécie apresenta os câmbios supernumerários eqüidistantes (dando a forma triangular ao câmbio central). 


\section{Sapindaceae}

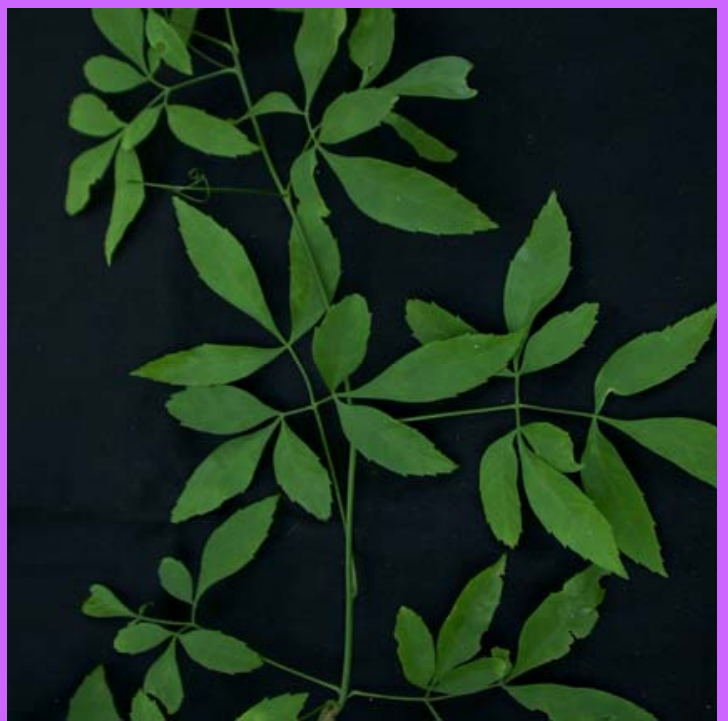

Serjania laruotteana Cambess.

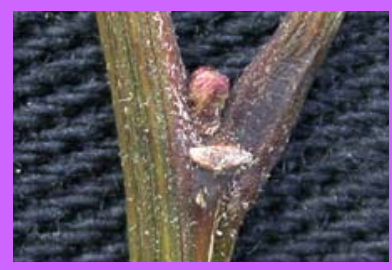

Cicatriz semi-lunar deixada com queda da estípula

\section{DICA DE CAMPO}

Além de apresentar folhas 2-ternadas, apresenta estípulas caducas, que deixam cicatriz semilunar.

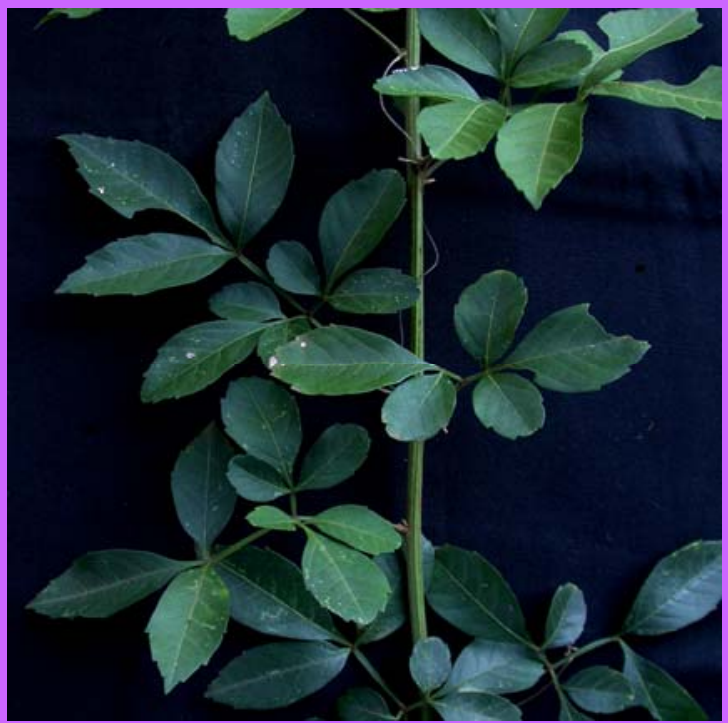

Serjania meridionalis Cambess.

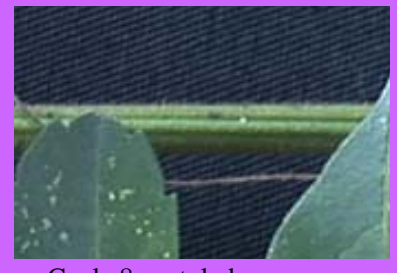

Caule 8-costulado

\section{DICA DE CAMPO}

Espécie de fácil reconhecimento, pois não apresenta câmbios supernumerários e as folhas são 2-ternadas. 


\section{Sapindaceae}

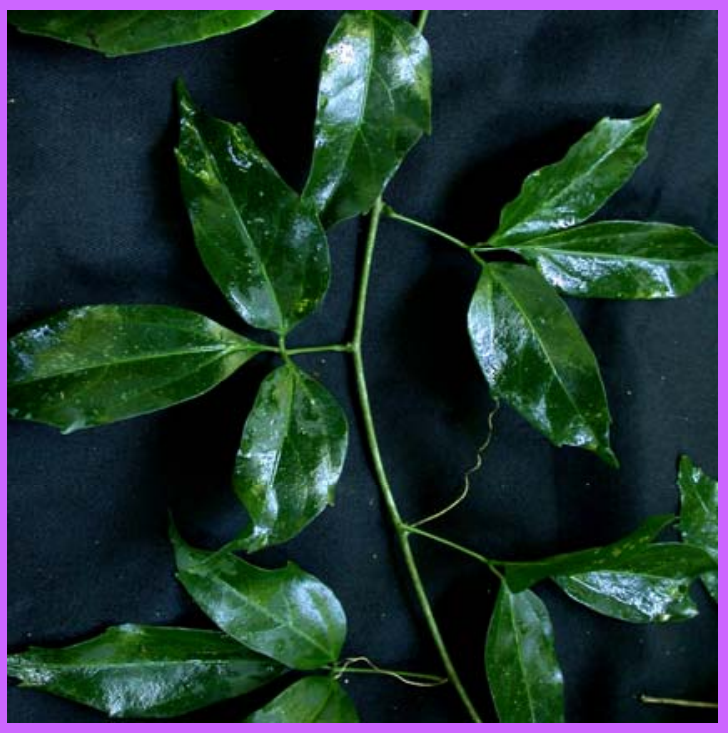

Thinouia ventricosa Radlk.

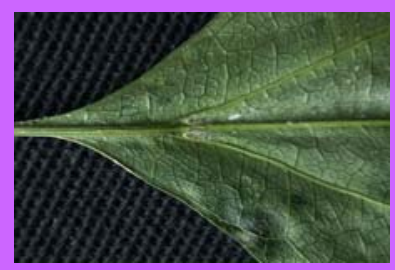

Folíolo triplinérvio e domácias

\section{DICA DE CAMPO}

Difere da outra espécie trifoliolada por apresentar folíolos triplinérveos e cartáceos.

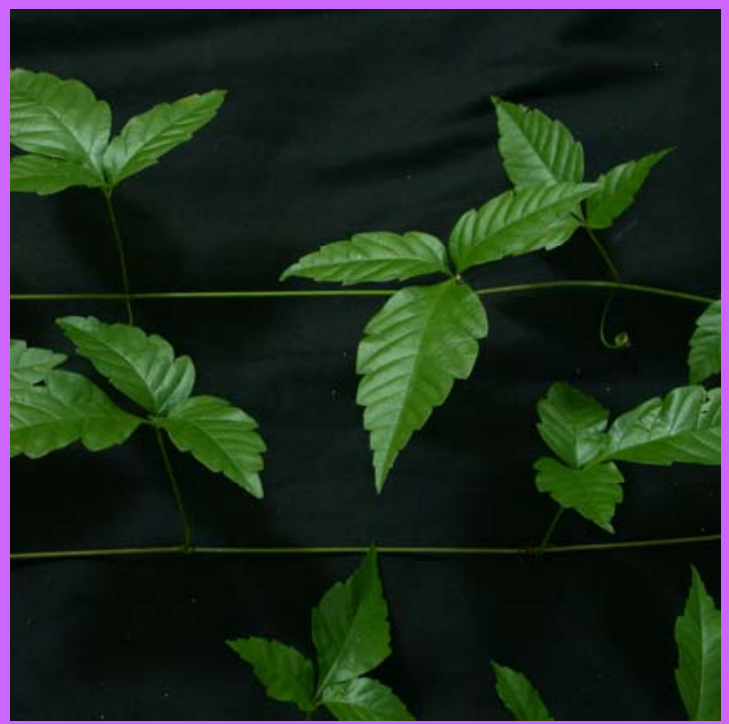

Urvillea laevis Radlk.

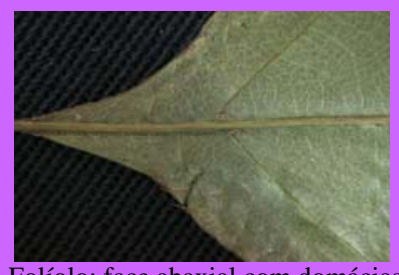

Folíolo: face abaxial com domácias

\section{DICA DE CAMPO}

Espécie muito abundante na Estação Ecológica. Além de ser 3-foliolada, apresenta folíolos membranáceos e estes são peninérveos. 


\section{Solanaceae}

Família com ampla distribuição, principalmente nas regiões tropicais e subtropicais da América do Sul. Conta com cerca de 2.260 espécies e 102 gêneros. Na área estudada foram encontradas 2 espécies de lianas lenhosas, as quais sempre estão associadas a áreas de clareiras e bordas de mata.

Inclui árvores pequenas ou, principalmente, arbustos, ervas e trepadeiras. Apresenta folhas simples e alternas e não apresenta estípulas. A inflorescência é do tipo cimeira ou ainda pode apresentar flores solitárias. As flores apresentam corola gamopétala e os estames são adnados ao tubo da corola. O fruto pode ser uma baga, cápsula ou drupa.

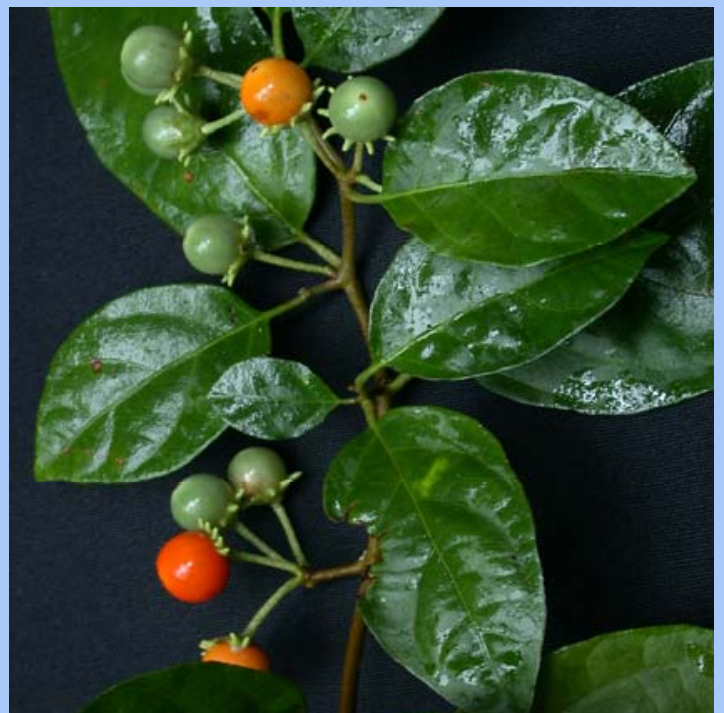

Lycianthes australe (Morton) A.T. Hunz. \& Barboza

\section{DICA DE CAMPO}

Pode ser diferenciada da outra espécie da família por apresentar face adaxial glabra e lustrosa.

\section{CHAVE DE IDENTIFICAÇÃO}

1. Folhas com face adaxial glabra e abaxial com tricomas estrelados, com 3 ou 4 ramificações

Lycianthes australe

1'. Folhas com face abaxial e adaxial com tricomas dendríticos, sempre com mais de 5 ramificações Solanum hirtellum

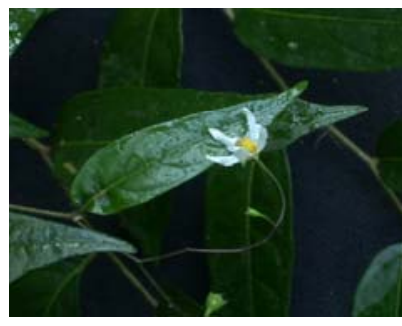

Detalhe do cálice de Lycianthes australe Flor de Solanum hirtellum
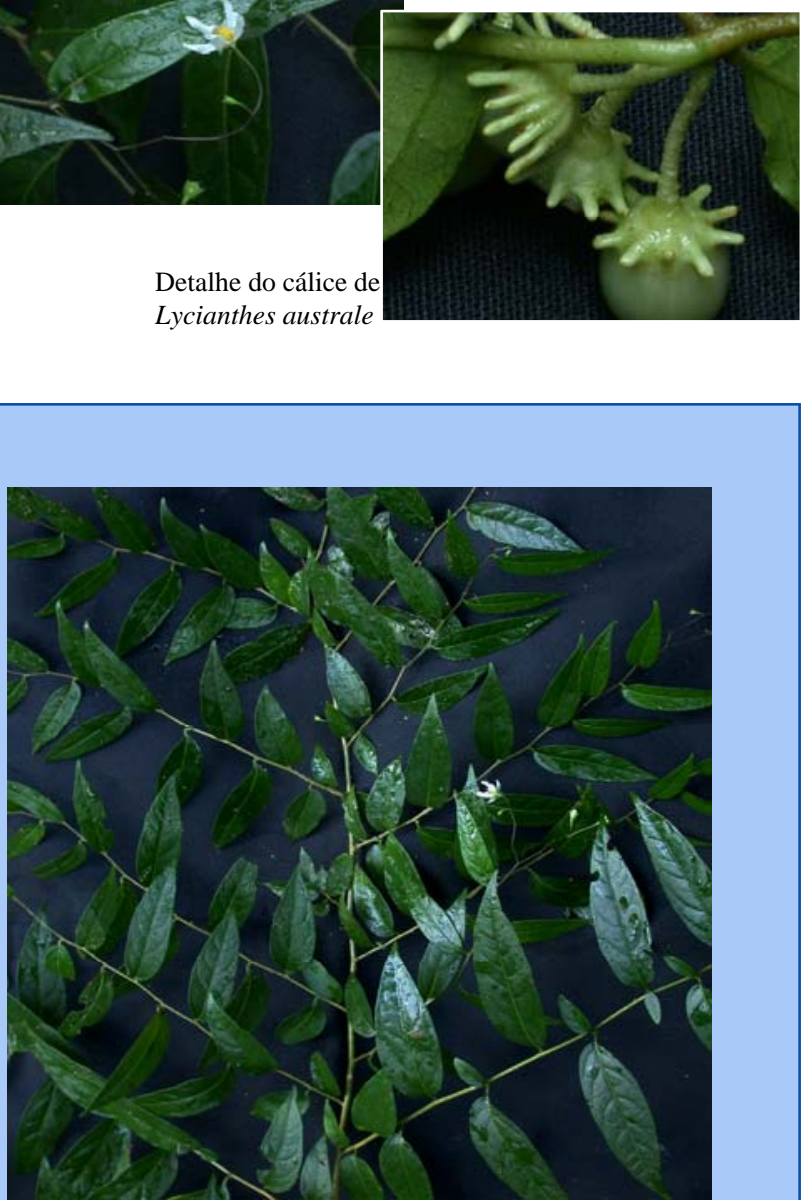

Solanum hirtellum (Spreng.) Hassl.

\section{DICA DE CAMPO}

Esta espécie apresenta grande quantidade de tricomas dendríticos em ambas as faces das folhas. 


\section{Sterculiaceae}

Família com cerca de 1.000 espécies distribuídas por 65 gêneros com ocorrência nas regiões tropicais e subtropicais do mundo. Nos neotrópicos podem ser encontrados 16 gêneros e cerca de 510 espécies. Houve o registro de apenas uma espécie de liana para a área estudada, Byttneria catalpifolia.

São árvores, arbustos ou lianas, com folhas alternas, com venação palmada na base. Apresentam estípulas e tricomas estrelados.

As flores são perfeitas (Byttneria) ou unissexuais, com espécies monóicas ou dióicas. Concentram-se em inflorescências multifloras, axilares ou terminais. Apresentam estames fundidos formando um tubo ao redor do ovário.

Recentemente, a partir de estudos moleculares, esta família foi incluída em Malvaceae, juntamente com Bombacaceae e Tiliaceae.

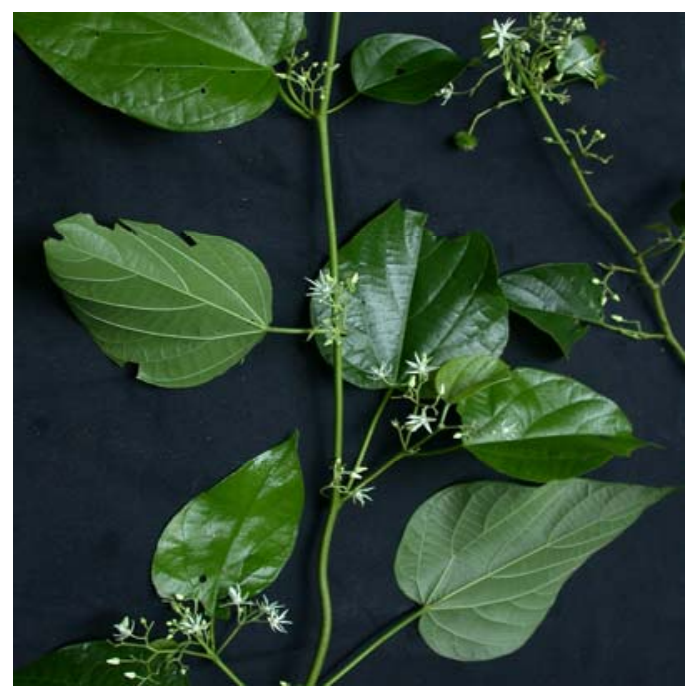

Byttneria catalpifolia Jacq.

\section{DICA DE CAMPO}

Dentre as espécies sem gavinhas e com folhas simples e alternas, esta é a única que apresenta folhas palminérveas.
Família com distribuição pantropical e temperada (nas regiões mais quentes), compreende 14 gêneros e cerca de 850 espécies. No local estudado é representada por uma única espécie, Cissus verticillata.

Grupo formado por lianas de fácil reconhecimento, mesmo em estado vegetativo, pois apresentam gavinhas opostas às folhas. Apresentam estípulas na base do pecíolo geralmente decíduas, margem foliar com apículos provindos das nervuras secundárias ou terciárias e ápice mucronado.

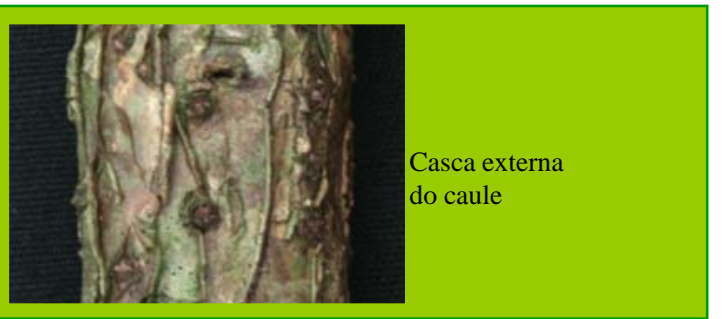

Cissus verticillata (L.) Nicolson \& C.E. Jarvis

\section{DICA DE CAMPO}

Esta é a única espécie da área que apresenta gavinhas opostas às folhas. 


\section{CHAVE DE IDENTIFICAÇÃO PARA AS FAMÍLIAS BASEADA APENAS NAS ESPÉCIES AMOSTRADAS}

1. Folhas opostas

2. Folhas compostas Bignoniaceae (Pág. 86)

2'. Folhas simples

3. Plantas com látex alvo ou incolor Apocynaceae (Pág. 83)

3’. Plantas sem látex

4. Plantas com gavinhas Loganiaceae (Pág. 96) $4^{\prime}$. Plantas sem gavinhas

5. Pecíolo ou limbo foliar com nectários extraflorais

Malpighiaceae (Pág. 96)

5'. Pecíolo ou limbo foliar sem nectários extraflorais

6. Folhas glabras Hippocrateaceae (Pág. 90) 6'. Folhas tomentosas

Asteraceae (Pág. 85)

$1^{\prime}$. Folhas alternas

7. Folhas compostas

8. Plantas com gavinhas

9. Folhas bifolioladas Leguminosae (Pág. 92)

9'. Folhas sempre com 3 ou mais folíolos Sapindaceae (Pág. 101) 8 . Plantas sem gavinhas

10. Plantas com estípulas e sem pontuações glandulosas nas folhas Leguminosae (Pág. 92) 10'. Plantas sem estípulas e com pontuações glandulosas de cor negra na face abaxial das folhas Connaraceae (Pág. 89) 
$7^{\prime}$. Folhas simples

11. Plantas com espinhos

12. Tufos de espinhos presentes ao longo do caule . Cactaceae (Pág. 89) $12^{\prime}$. Espinhos aos pares, presentes na base dos ramos

Phytolaccaceae (Pág. 100)

$11^{\prime}$. Plantas inermes

13. Plantas com ócrea que, quando se desprende do caule, deixa cicatriz conspícua Polygonaceae (Pág. 100) $13^{\prime}$. Ócrea ausente

14. Plantas com gavinhas opostas aos pecíolos ... Vitaceae (Pág. 103) $14^{\prime}$. Plantas sem gavinhas

15. Folhas deltóides; pseudoestípulas foliáceas Aristolochiaceae (Pág. 85)

15'. Folhas ovadas, largamente ovadas ou lanceoladas; pseudoestípulas ausentes

16. Folhas com margem serrilhada ......... Violaceae (Pág. 103)

$16^{\prime}$. Folhas com margem inteira ... Menispermaceae (Pág. 99) 


\section{Apocynaceae}

Apocynaceae é uma família com cerca de 415 gêneros e 4.500 espécies, amplamente distribuída por regiões tropicais e subtropicais, com poucos representantes em regiões temperadas. No Brasil ocorrem cerca de 41 gêneros e 400 espécies. Para a área de estudo foram registradas 4 espécies, pertencentes a 4 gêneros distintos.

O hábito nesse grupo é bastante variável, podendo ocorrer, além de lianas, ervas, arbustos e árvores. São plantas geralmente com látex alvo e abundante. As flores são bissexuais e geralmente vistosas, com corola tubulosa e os lobos torcidos no botão (prefloração contorta). Os filetes são unidos ao tubo da corola.

Recentemente, a partir de estudos moleculares, foi incluída nesta família as “Asclepiadaceae”.

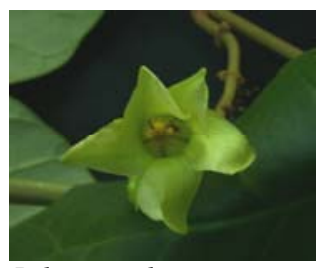

Peltastes peltatus

\section{CHAVE DE IDENTIFICAÇÃO}

1. Folhas peltadas Peltastes peltatus

1'. Folhas não peltadas

2. Folhas verticiladas Secondatia densiflora

2'. Folhas opostas

3. Folhas com domácias urceoladas na face superior Forsteronia sp.

3’. Folhas sem domácias

Prestonia coalita

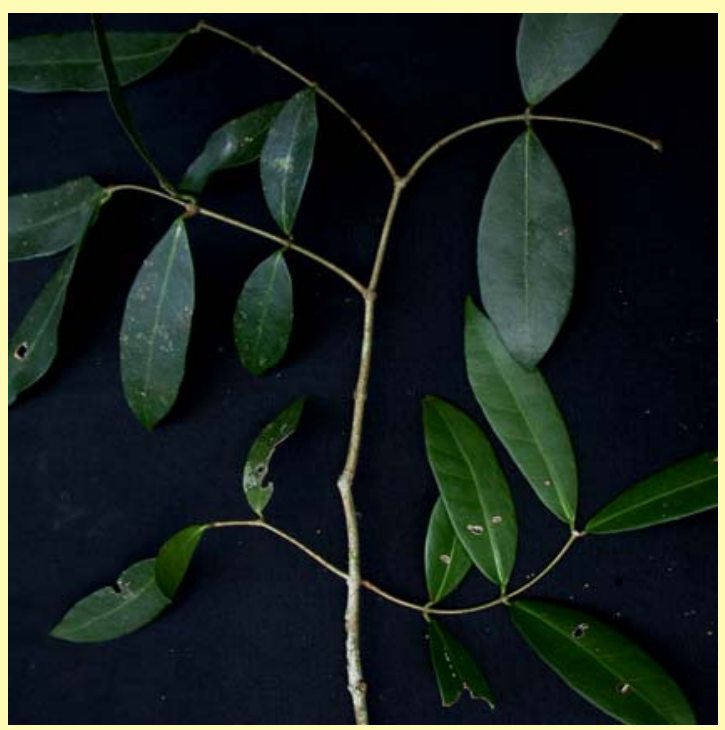

Forsteronia sp.

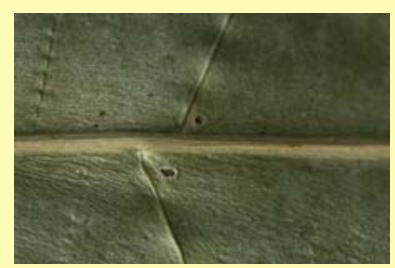

Domácias urceoladas

\section{DICA DE CAMPO}

Esta espécie pode ser reconhecida principalmente por apresentar folhas com domácias urceoladas. 


\section{Apocynaceae}

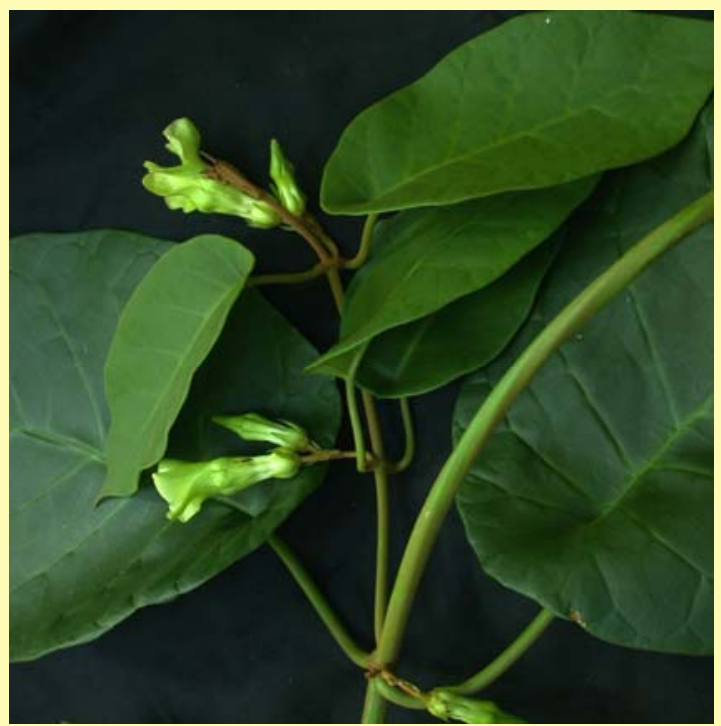

Peltastes peltatus (Vell.) Woodson

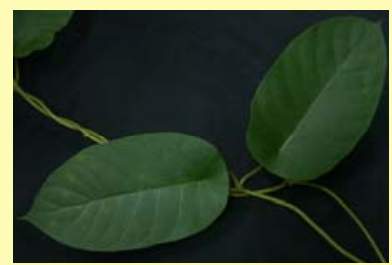

Folhas peltadas

\section{DICA DE CAMPO}

Esta é a única espécie de liana, dentre as encontradas na área, que apresenta folhas peltadas e látex incolor.

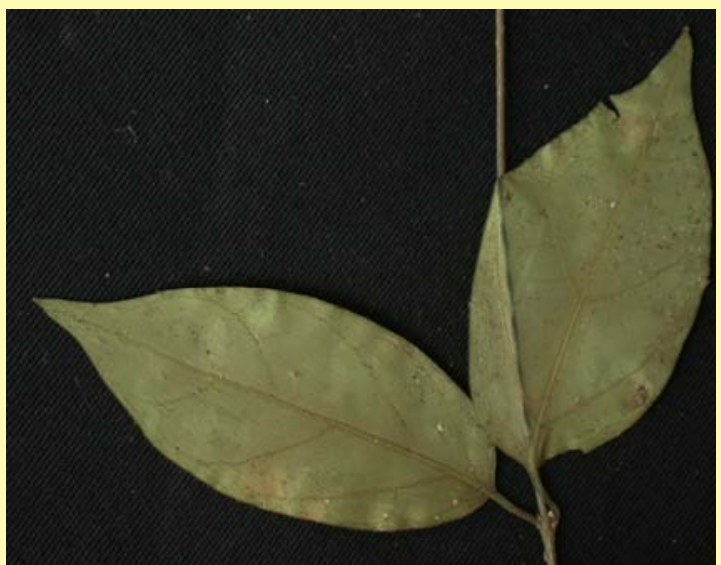

Prestonia coalita (Vell.) Woodson

\section{DICA DE CAMPO}

Esta espécie pode facilmente ser diferenciada de Forsteronia sp. por não apresentar domácias na face inferior do limbo.

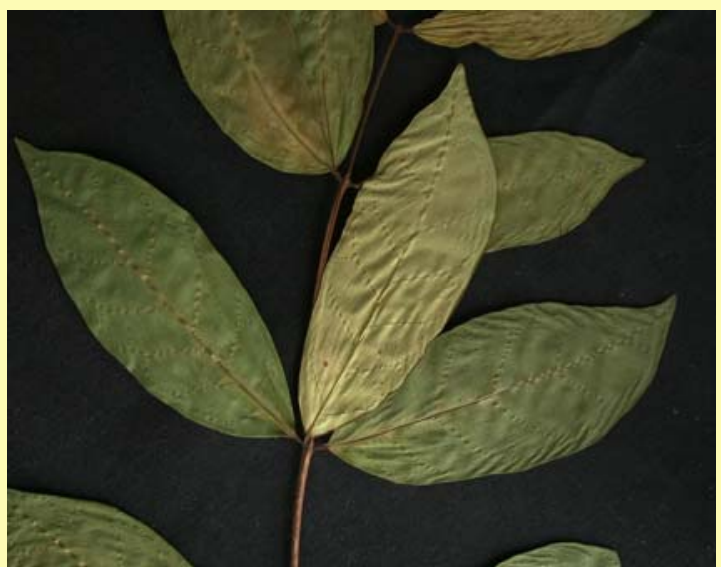

Secondatia densiflora A. DC.

\section{DICA DE CAMPO}

Esta é a única, dentre as encontradas na área, que apresenta folhas verticiladas. 


\section{Aristolochiaceae}

Família constituída por 7 gêneros e cerca de 650 espécies em regiões tropicais, subtropicais e temperadas de todo o mundo, sendo representada nos neotrópicos por 3 gêneros e cerca de 260 espécies. Na área de estudo foi encontrada uma única espécie, Aristolochia paulistana.

Grupo composto predominantemente por lianas, também apresentando espécies com porte herbáceo ou arbustivo. As folhas são alternas, em geral cordiformes ou reniformes e a presença de pseudoestípulas é freqüente. As flores são zigomórfas, com as tépalas unidas em tubo, freqüentemente infladas na base. Apresentam 5 a 6 estames unidos com o estilete, formando o ginostêmio. O ovário é ínfero e os frutos são do tipo cápsula.

Podem ser confundidas, vegetativamente, com as Menispermaceae, sendo facilmente reconhecidas pela anatomia do caule, que forma secções radiadas, pela presença de uma pequena cavidade no ponto de inserção do pecíolo e pela ausência de engrossamento no ápice do mesmo.

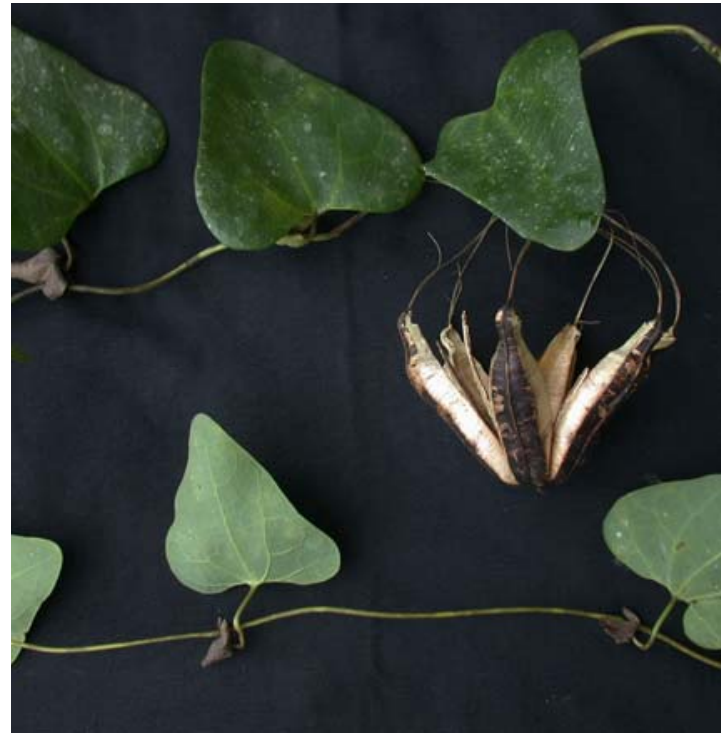

Aristolochia paulistana Hoehne

\section{DICA DE CAMPO}

Única espécie encontrada na área que, além de apresentar folhas simples e deltóides, possui pseudoestípulas foliáceas persistentes.

\section{Asteraceae}

A família Asteraceae está entre as maiores das Angiospermas, com cerca de 22.750 espécies, distribuídas por cerca de 1.500 gêneros. Apresenta distribuição cosmopolita, não sendo encontrada apenas no continente Antártico. Tratase de um grupo bem representado nas formações vegetacionais campestres, ocorrendo poucas espécies nas florestas Atlântica de Encosta e Amazônica. Na área estudada foi encontrada uma única espécie, Mikania hirsutissima.

Esta é uma família muito diversificada em relação ao hábito, existindo desde espécies herbáceas até arbustos, árvores e lianas. Considerando as lianas, estas ainda podem ser volúveis, escandentes ou apresentarem gavinha (como em Mutisia). A principal característica da família é a inflorescência em capítulo.

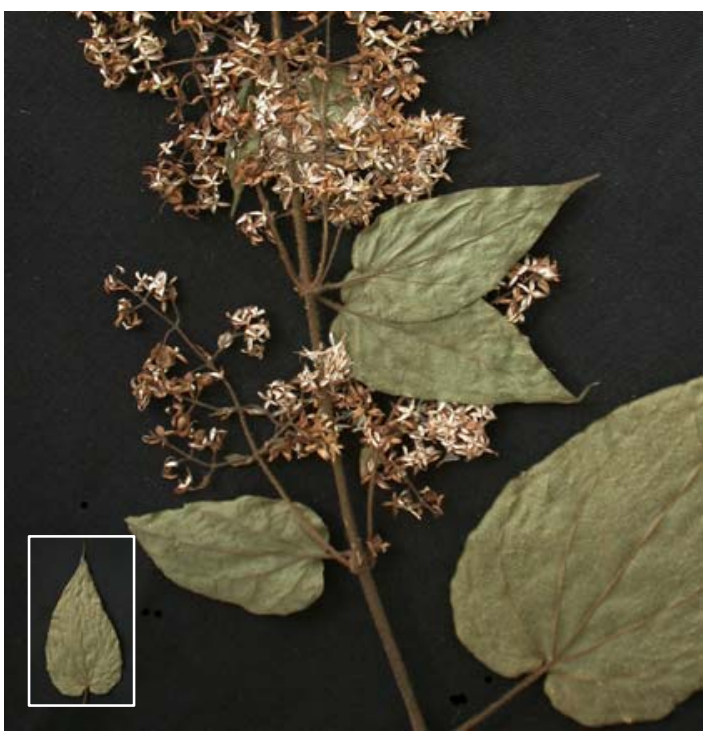

Mikania hirsutissima DC.

\section{DICA DE CAMPO}

Esta espécie apresenta folhas cordiformes com ápice caudado e indumento tomentoso ao longo do caule e folhas. 


\section{Bignoniaceae}

Família com cerca de 800 espécies e 113 gêneros, distribuídos por 8 tribos. Apresenta distribuição predominantemente neotropical, com poucas espécies nas regiões temperadas.

No trecho da formação florestal estudada é representada por 4 espécies de lianas de 4 gêneros diferentes. As lianas dessa família podem facilmente ser reconhecidas no campo pelos nós espessados, mesmo após a queda das folhas, que são opostas e compostas, pelo floema arranjado em forma de cruz, na maioria das espécies, e pelo folíolo terminal geralmente modificado em gavinha, a qual pode ser simples ou trífida. As flores são caracterizadas por apresentar corola gamopétala, 4 estames didínamos, um estaminódio e estigma bífido. Os frutos, em geral, são cápsulas achatadas com sementes aladas. Algumas espécies podem ser hemiepífitas, como é o caso de Schlegelia parviflora, que apresenta raízes grampiformes.

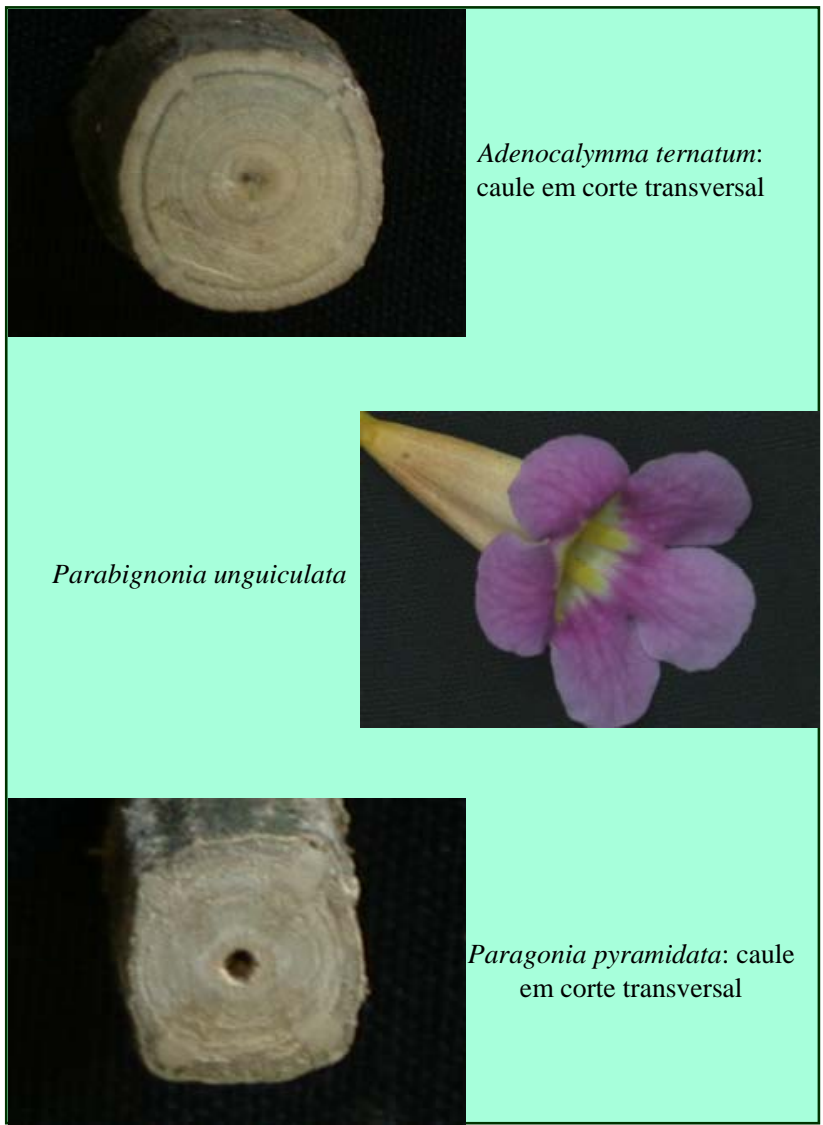

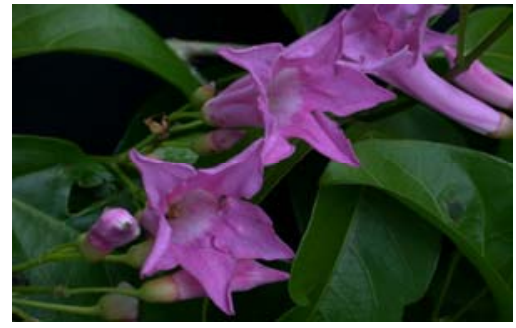

Paragonia pyramidata

\section{CHAVE DE IDENTIFICAÇÃO}

1. Gavinha simples

2. Folíolos glabros, com base aguda Anemopaegma lanceolatum

2’. Folíolos com face inferior hirsuta, com base cordada Adenocalymma ternatum

1’. Gavinha trífida

3. Gavinha uncinada; nectários
concentrados na região interpeciolar
.............................. Parabignonia unguiculata

3’. Gavinha não uncinada; nectários ausentes na região interpeciolar Paragonia pyramidata

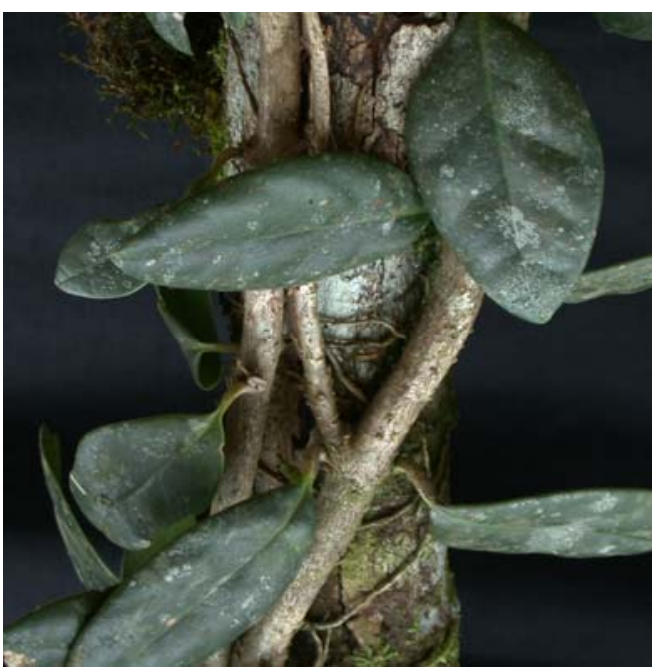

Raízes grampiformes de Schlegelia parviflora (Bignoniaceae hemiepífita de folhas simples) 


\section{Bignoniaceae}

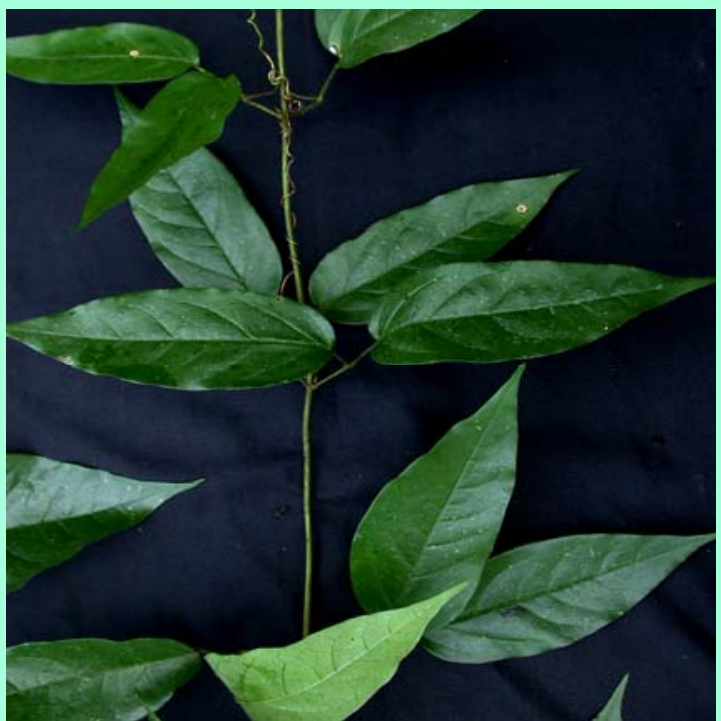

Adenocalymma ternatum (Vell.)

Corr. Méllo ex Bureau \& K. Schum.

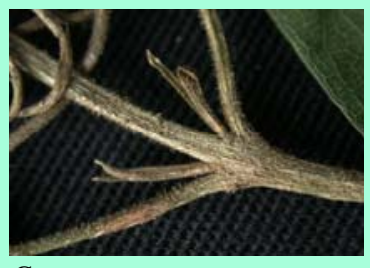

Gema

\section{DICA DE CAMPO}

Esta é a única espécie de Bignoniaceae, encontrada no Parque, que apresenta indumento hirsuto.

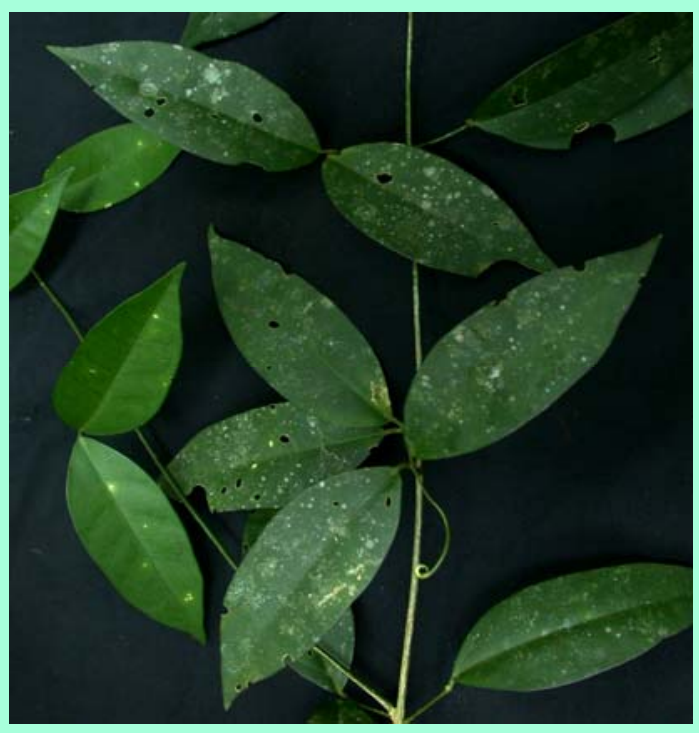

Anemopaegma lanceolatum (A. DC.) Bureau ex Schumann

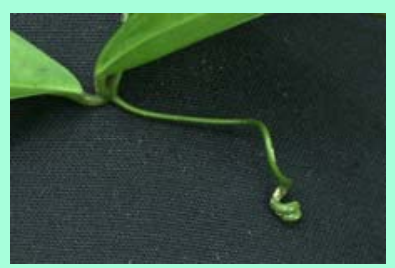

Gavinha

\section{DICA DE CAMPO}

Única Bignoniaceae ocorrente na área estudada que apresenta, ao mesmo tempo, folhas glabras e gavinha simples. 


\section{Bignoniaceae}

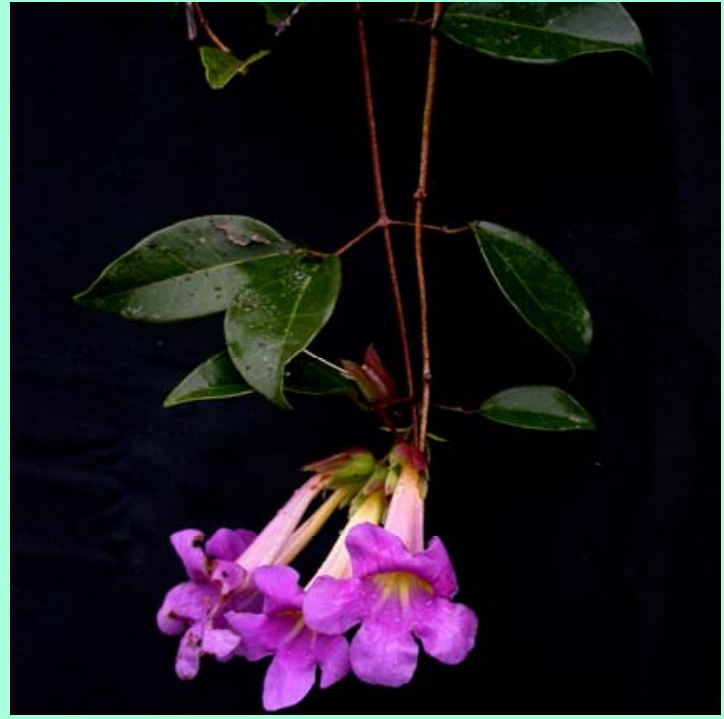

Parabignonia unguiculata (Vell.) A.H. Gentry

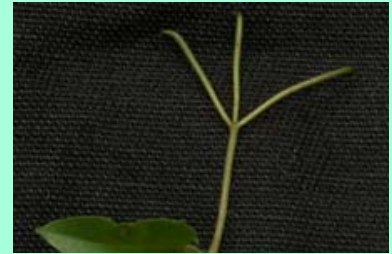

Gavinha uncinada

\section{DICA DE CAMPO}

Esta é uma das espécies conhecidas popularmente por unha-de-gato, pois apresenta gavinha trífida e uncinada. Apresenta nectários concentrados na região interpeciolar, o que a diferencia de Paragonia pyramidata.

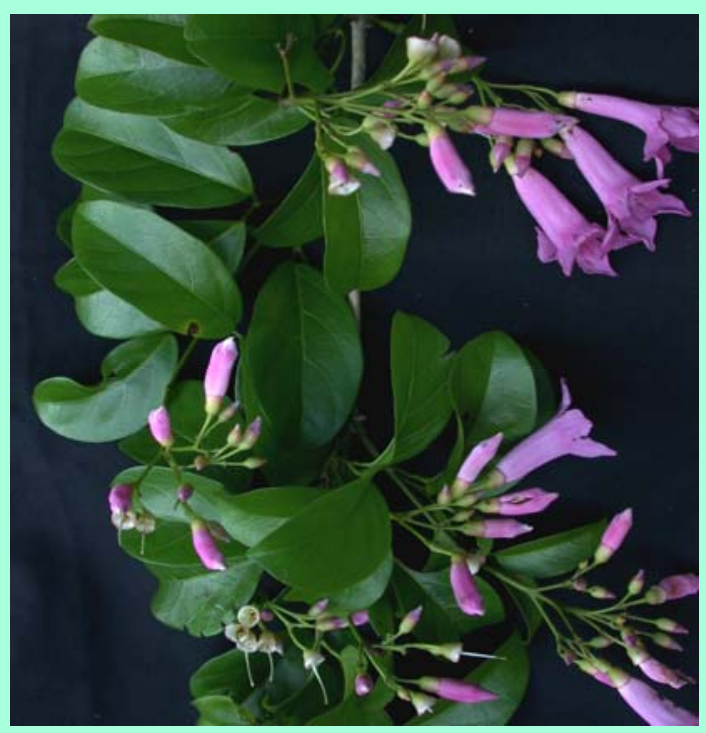

Paragonia pyramidata (Rich.) Bureau

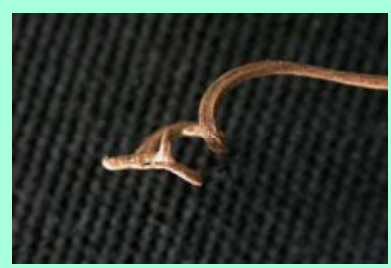

Gavinha trífida, não uncinada

\section{DICA DE CAMPO}

Esta espécie apresenta gavinhas trífidas mas não uncinadas. Pode facilmente ser diferenciada de Parabignonia unguiculata por não apresentar nectários concentrados na região interpeciolar. 


\section{Cactaceae}

Família com distribuição neotropical representada por cerca de 1.500 espécies, distribuídas por 100 gêneros. Em geral são adaptadas às condições áridas, mas também existem lianas e epífitas em florestas úmidas. $\mathrm{Na}$ área estudada há o registro de uma única espécie de liana, Pereskia aculeata.

Em geral são epífitas, arbustos ou árvores, raramente lianas. O caule apresenta tufos de espinhos que ficam reunidos em estruturas denominadas aréolas. As folhas, em geral, são reduzidas ou ausentes (são conspícuas em Pereskia e Quiabentia). Apresenta flores bissexuadas, com muitas tépalas e estames; ovário ínfero com um estilete e de um a muitos estigmas. O fruto é geralmente uma baga com numerosas sementes.

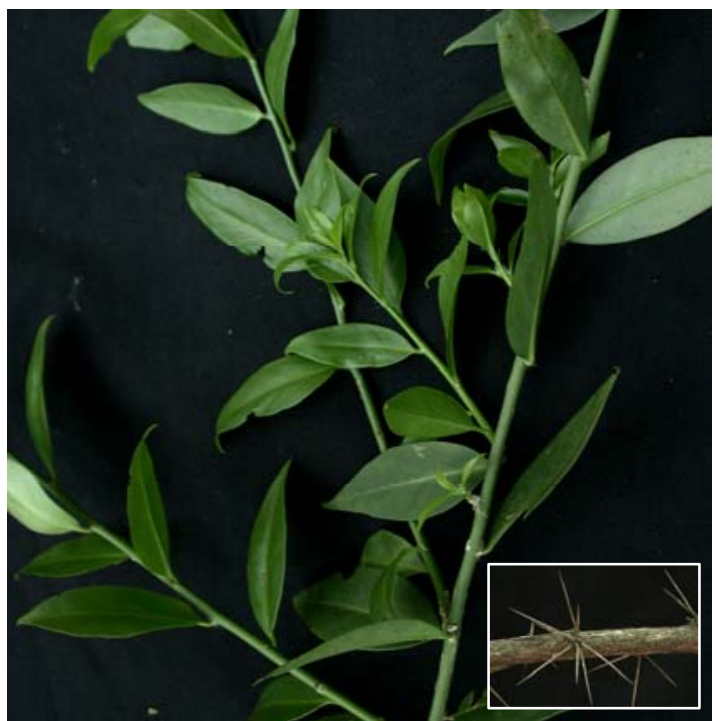

Pereskia aculeata Mill.

\section{DICA DE CAMPO}

Esta planta pode ser caracterizada por apresentar espinhos no caule, folhas de consistência carnosa e com apenas a nervura central bem evidente.

\section{Commaraceae}

Connaraceae apresenta distribuição pantropical, com cerca de 180 espécies, distribuídas por 12 gêneros. Na região neotropical é representada por 5 gêneros. No Parque há o registro de uma única espécie, Connarus rostratus.

Connaraceae pode apresentar hábito arbóreo ou lianescente. São plantas sem estípulas e com folhas imparipinadas e alternas. As flores são pequenas, em geral alvo-amareladas, pentâmeras ou, mais raramente, tetrâmeras. As sépalas geralmente são persistentes nos frutos. O androceu é formado por 10 estames concrescidos na base e o gineceu é apocárpico, formado por 5 carpelos. Apresenta fruto seco capsular (folículo), sendo que geralmente um único carpelo se desenvolve.

Esta família é comumente confundida com Leguminosae, mas pode ser distinguida por não apresentar estípulas.

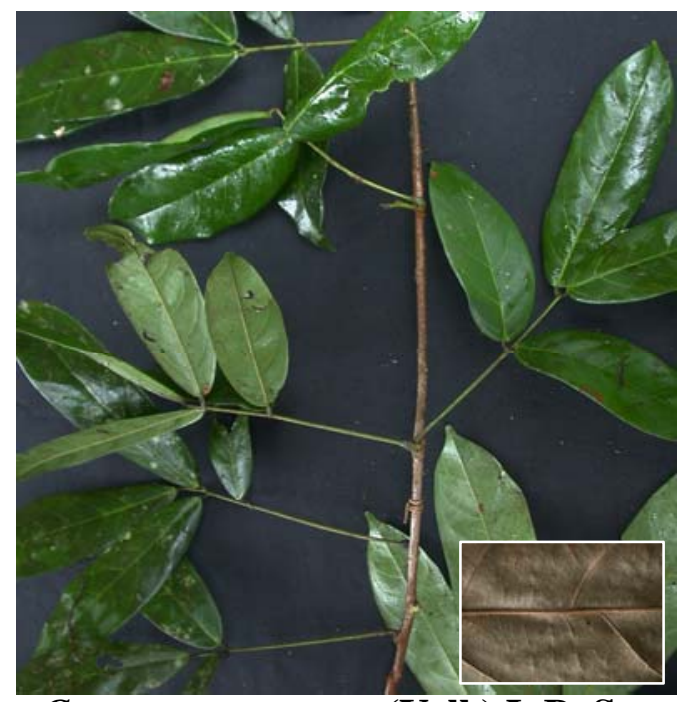

Connarus rostratus (Vell.) L.B. Sm.

\section{DICA DE CAMPO}

Esta espécie é comumente confundida com Leguminosae, mas é facilmente diferenciada desse grupo por apresentar pontuações glandulosas de cor negra nos folíolos (detalhe) e por não apresentar estípulas. 


\section{Hippocrateaceae}

Esta família conta com 12 gêneros e cerca de 120 espécies, distribuídas pela região neotropical, sendo a bacia amazônica o centro de diversidade para o grupo. Foram encontradas apenas 3 espécies na área estudada.

São plantas lenhosas, podendo ser arbustos, árvores ou lianas. As lianas, em geral, apresentam modificações no caule denominadas "ganchos", os quais auxiliam na fixação ao suporte. As folhas são opostas, com estípulas pequenas e caducas, raramente persistentes. As flores são pequenas, com coloração variando de amarela a esverdeada, pentâmeras, com corola dialipétala; apresenta disco nectarífero. O androceu é formado por 3 (-5) estames e o ovário é súpero. Fruto drupáceo, baciforme ou capsular, com sementes freqüentemente aladas.

Esta família foi recentemente, a partir de estudos moleculares, incluída em Celastraceae.

\section{CHAVE DE IDENTIFICAÇÃO}

1. Folhas com margem serrilhada Anthodon decussatum

1'. Folhas com margem inteira

2'. Nervuras secundárias sulcadas na face inferior das folhas Salacia elliptica

2. Nervuras secundárias salientes na face inferior das folhas

3. Folhas sempre maiores que 17 $\mathrm{cm}$, margem revoluta Tontelea sp.

3’. Folhas sempre menores que $13 \mathrm{~cm}$, margem não revoluta

4. Ápice agudo Salacia mossenii

4’. Ápice acuminado Peritassa sp.

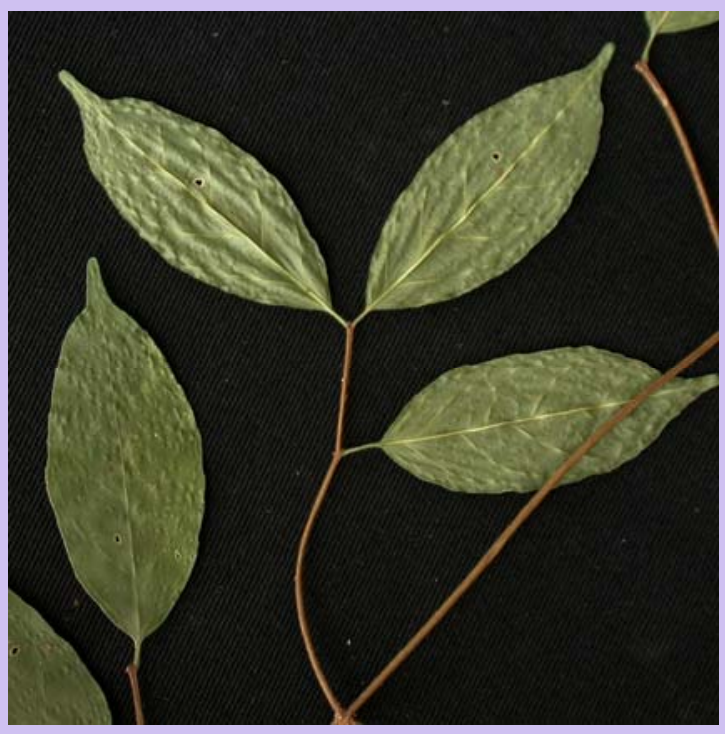

Anthodon decussatum Ruiz \& Pav.

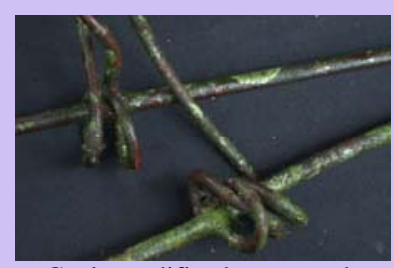

Caule modificado em gancho

\section{DICA DE CAMPO}

Única espécie de Hippocrateaceae encontrada no Parque que apresenta folhas com bordo serrilhado. 


\section{Hippocrateaceae}

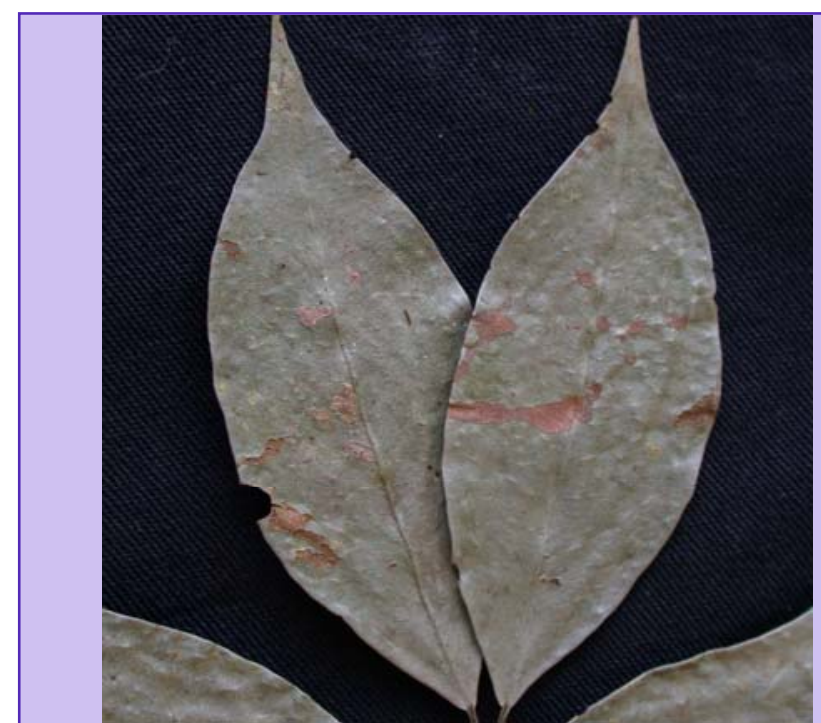

Peritassa sp.

\section{DICA DE CAMPO}

Esta espécie apresenta folhas com ápice acuminado e caule formando grande quantidade de ganchos.

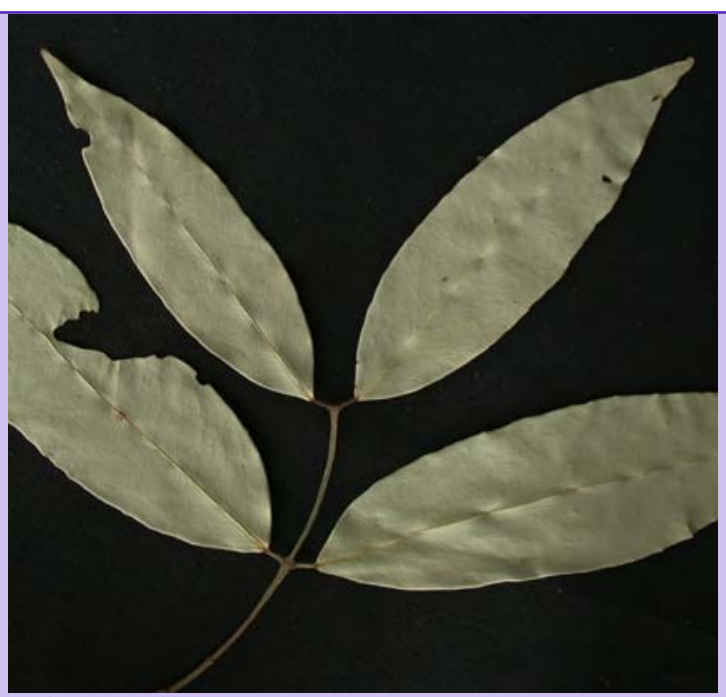

Salacia elliptica (Mart. ex Schult.) G. Don

\section{DICA DE CAMPO}

Apresenta folhas com nervuras secundárias sulcadas na face inferior. Os ganchos não ocorrem em grande quantidade.

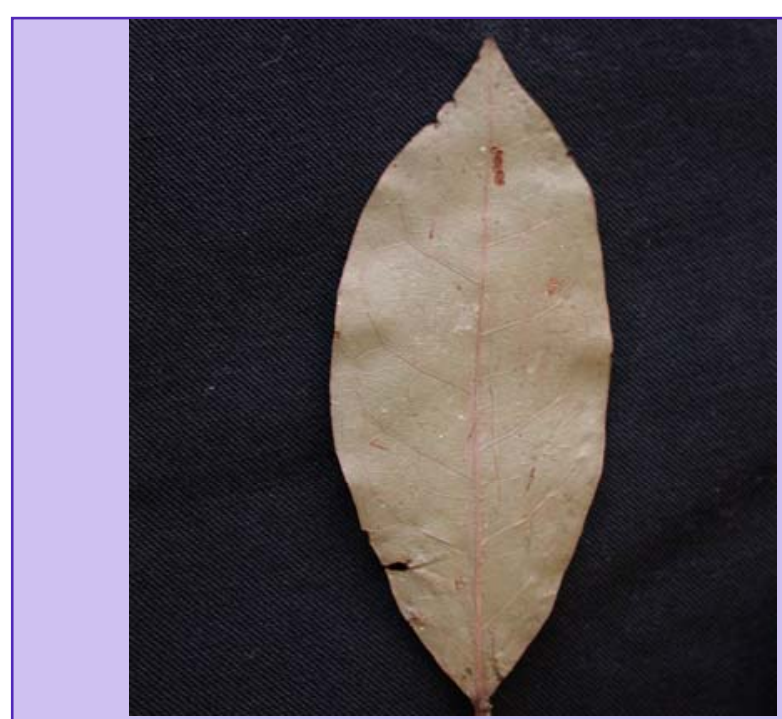

Salacia mosenii A.C. Sm.

\section{DICA DE CAMPO}

Esta espécie difere de Peritassa sp. por apresentar folhas com ápice agudo e ganchos em pouca quantidade.

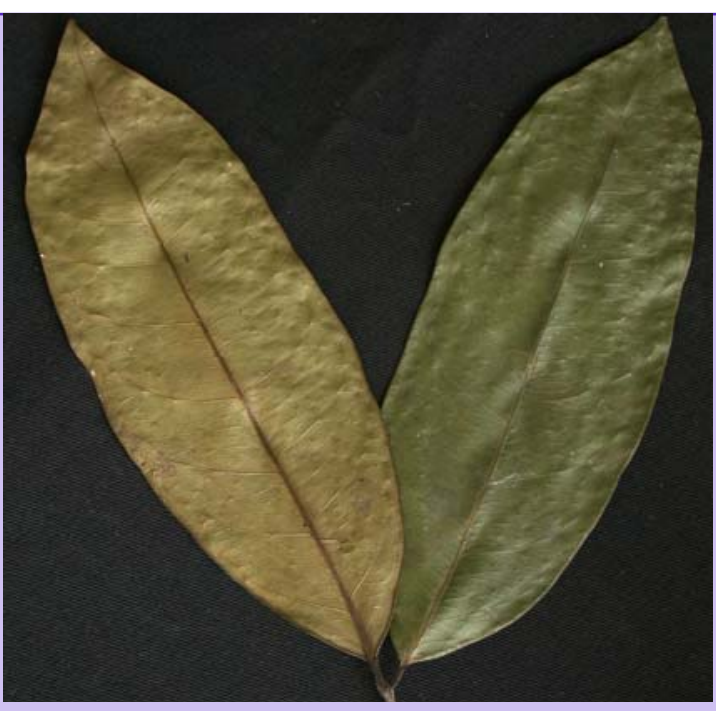

\section{Tontelea sp.}

\section{DICA DE CAMPO}

Nesta espécie as folhas sempre são maiores que $17 \mathrm{~cm}$ e há grande quantidade de ganchos (caule modificado). 


\section{Leguminosae}

Esta família é uma das maiores, dentre as Angiospermas, com cerca de 18.000 espécies distribuídas por 642 gêneros. Apresenta distribuição cosmopolita, estando representada principalmente nas regiões tropicais e subtropicais.

São plantas de hábito muito variado, podendo existir árvores, arbustos, ervas ou lianas, as quais podem ser herbáceas ou lenhosas. Podem viver nos mais variados ambientes, em diferentes latitudes e altitudes. As folhas são alternas e compostas, com estípulas e estipelas às vezes transformadas em espinhos; com pulvinos na base dos pecíolos e peciólulos. Essa família é subdividida em 3 subfamílias:

Caesalpinioideae: 180 gêneros e 2.500 espécies; apresenta prefloração da corola imbricada ascendente.

Faboideae: 500 gêneros e 10.000 espécies; apresenta prefloração da corola imbricada descendente.

Mimosoideae: 60 gêneros e 3.000 espécies; apresenta prefloração valvar.

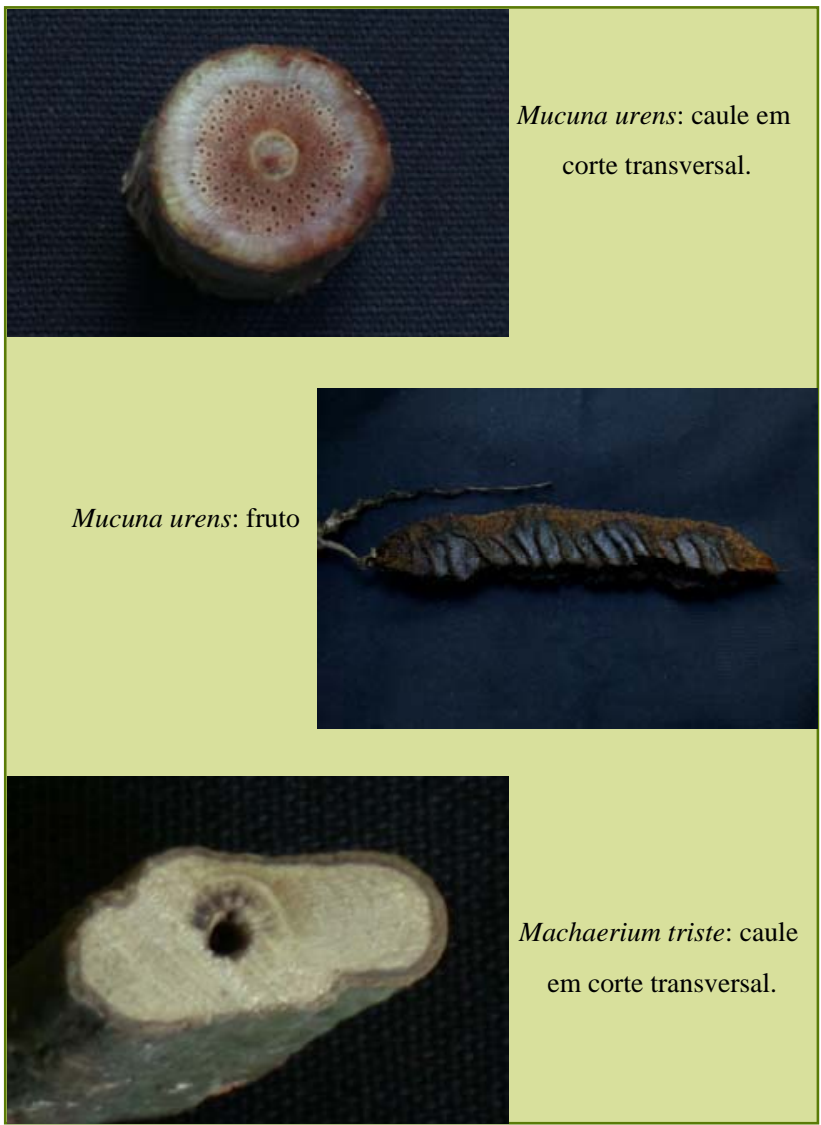

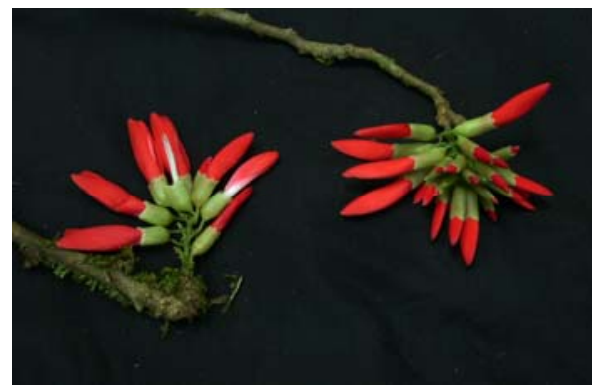

Dahlstedtia pentaphylla

\section{CHAVE DE IDENTIFICAÇÃO}

1. Folhas bicompostas Acacia lacerans

1'. Folhas 2-3-foliolada ou pinadas

2. Folhas bifolioladas com folíolos fundidos .. Bauhinia microstachya

2’. Folhas com mais de 2 folíolos

3. Folhas 3-folioladas Mucuna urens

3’. Folhas pinadas

4. Folhas 5(7)-folioladas; planta escandente ..... Dahlstedtia pentaphylla

4’. Folhas com 8 ou mais folíolos; plantas volúveis.

5. Folíolos discolores; caule sem espinhos nos ganchos Dalbergia frutescens

5’. Folíolos concolores; caule com espinhos nos ganchos Machaerium triste

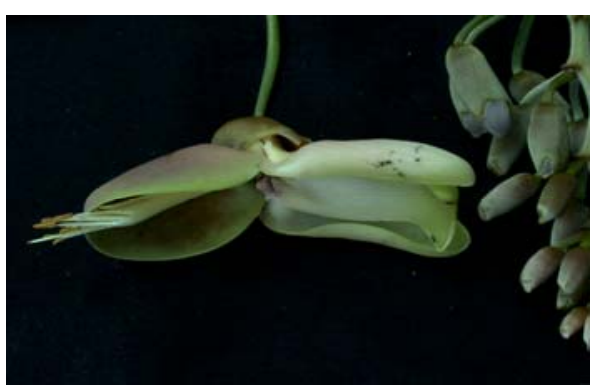

Mucuna urens: flor 


\section{Leguminosae - Caesalpinioideae}

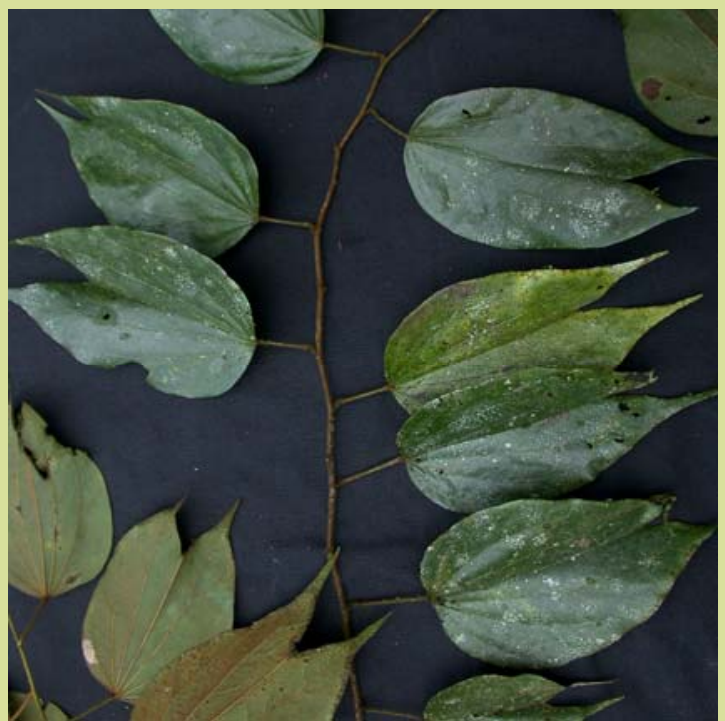

Bauhinia microstachya (Raddi) J.F. Macbr.

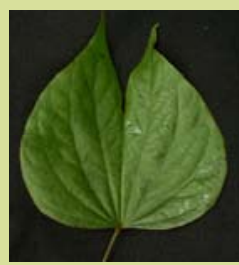

Folha: face superior

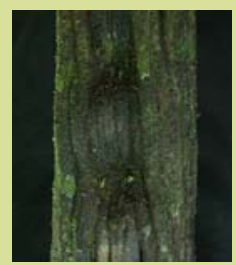

Caule: escada-de-macaco

\section{DICA DE CAMPO}

Esta espécie é conhecida popularmente por escada-de-macaco (devido à forma do caule). Suas folhas são bifolioladas com folíolos unidos e apresentam grande quantidade de tricomas ferrugíneos na face inferior. As gavinhas apresentam porção apical espessa.

\section{Leguminosae - Faboideae}

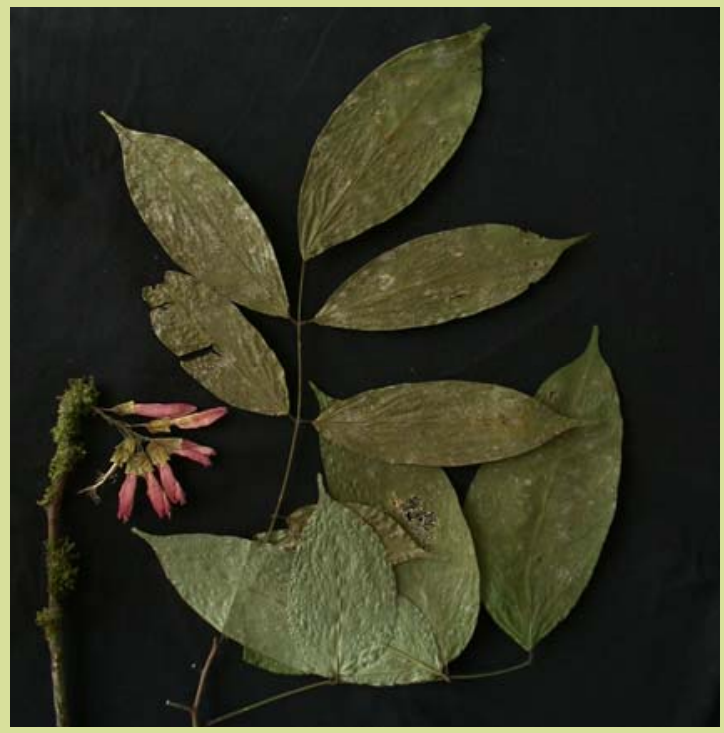

Dahlstedtia pentaphylla (Taub.) Burkart

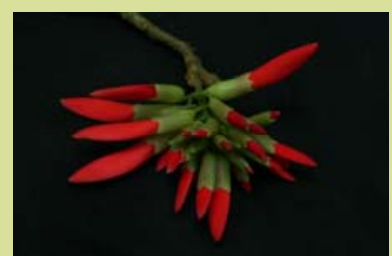

Flores

DICA DE CAMPO

Planta escandente, com folhas 5(7)folioladas. Esta espécie também pode ser encontrada com hábito arbóreo. 


\section{Leguminosae - Faboideae}

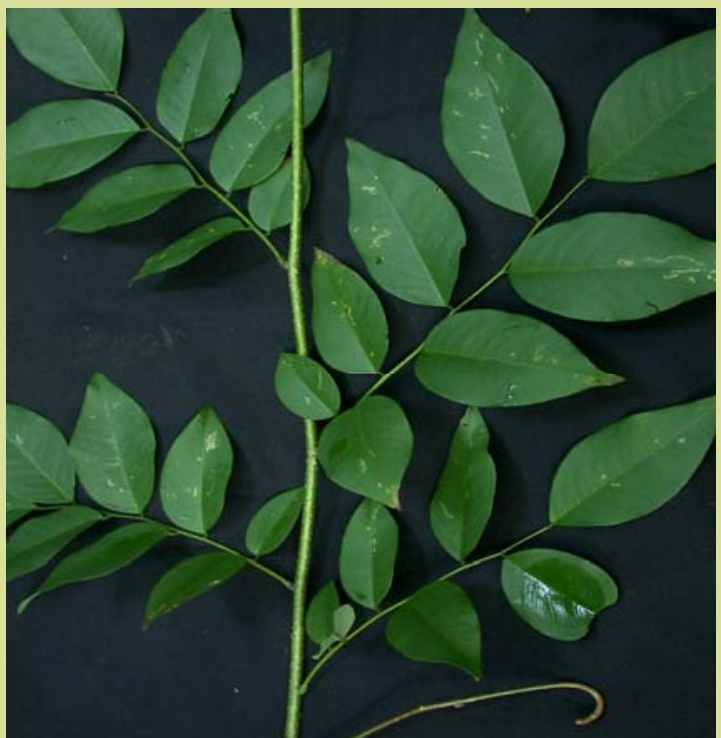

Dalbergia frutescens (Vell.) Britton

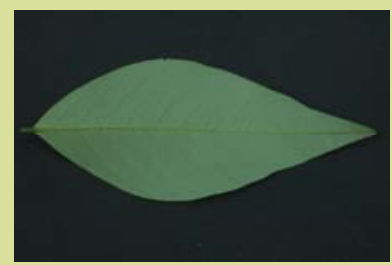

Foliolo: face inferior

\section{DICA DE CAMPO}

Essa espécie pode ser caracterizada por apresentar folíolos discolores (a face inferior é verde acinzentada) com nervuras secundárias paralelas e próximas umas das outras. O caule apresenta modificações com a forma de gancho, sem espinhos.

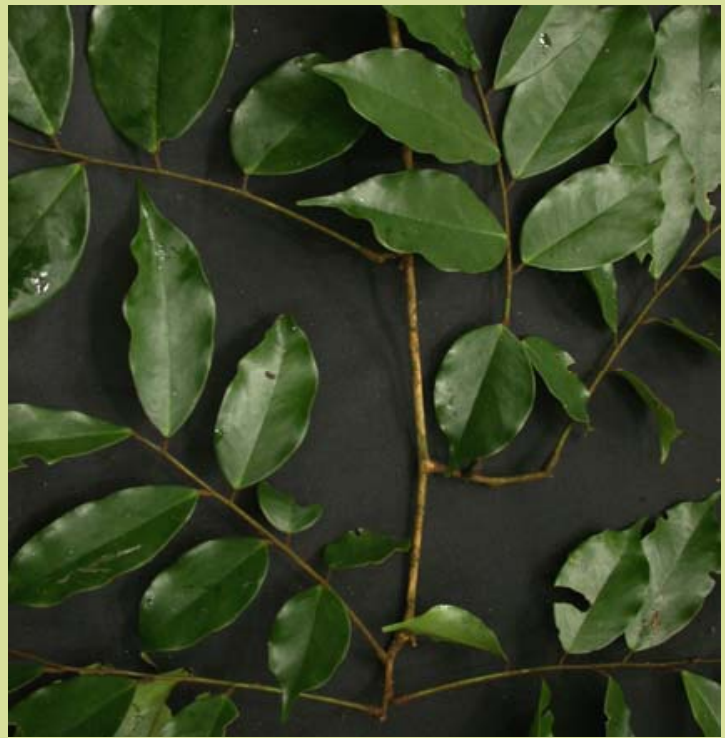

Machaerium triste Vogel

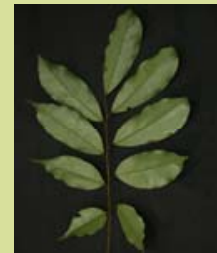

Folha: face superior

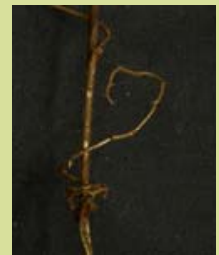

Caule modificado em gancho

\section{DICA DE CAMPO}

Essa espécie apresenta folíolos com ápice acuminado e os ganchos (caule modificado) apresentam espinhos. 


\section{Leguminosae - Faboideae}

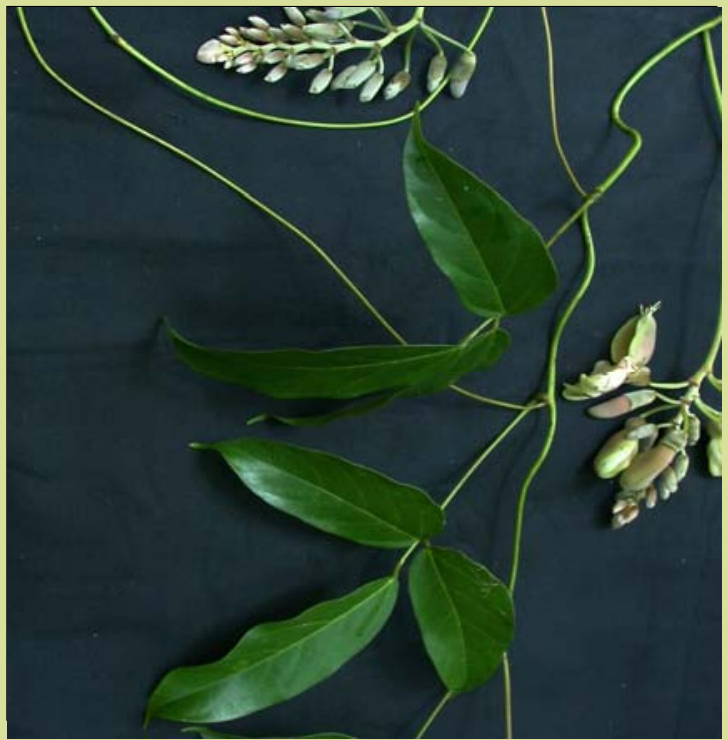

Mucuna urens (L.) Medik.

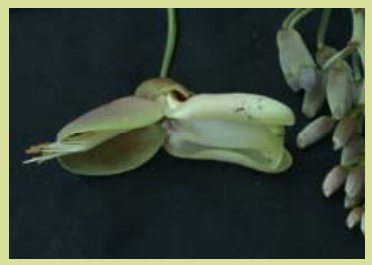

Flor

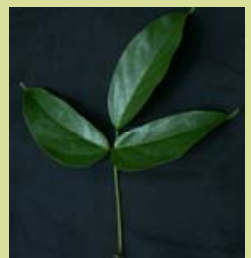

Folha: face superior

\section{DICA DE CAMPO}

Apresenta folhas 3-folioladas, sendo os folíolos laterais assimétricos. O pedúnculo é muito longo, podendo atingir mais de $1,5 \mathrm{~m}$.

\section{Leguminosae - Mimosoideae}

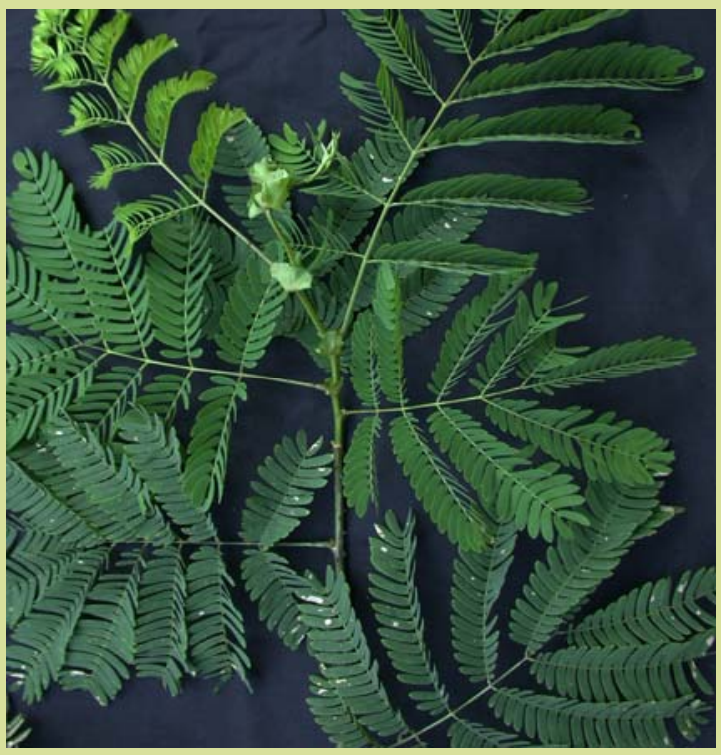

Acacia lacerans Benth.

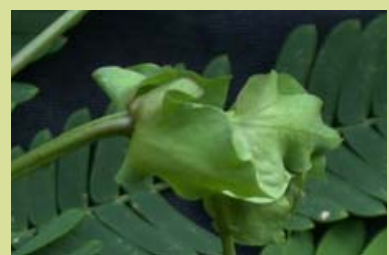

Estípula foliácea

DICA DE CAMPO

Única Leguminosae encontrada na área de estudo que apresenta espinhos ao longo do caule e estípulas foliáceas. 


\section{Loganiaceae}

Trata-se de uma família bastante heterogênea morfologicamente que compreende 13 gêneros e 420 espécies. Ocorre predominantemente nas regiões tropicais e subtropicais de todo mundo. $\mathrm{Na}$ área abrangida pelo estudo foi encontrada uma única espécie, Strychnos trinervis.

São plantas herbáceas, arbustivas, arbóreas ou lianas, com folhas opostas ou verticiladas, com margem inteira, com estípulas. As flores são actinomorfas, diclamídeas, tetrâmeras ou pentâmeras e perfeitas. Os estames apresentam-se em número igual ao das pétalas e são alternos a elas. O ovário é súpero e o fruto uma cápsula loculicida, baga (Strychnos) ou drupa carnosa e indeiscente.

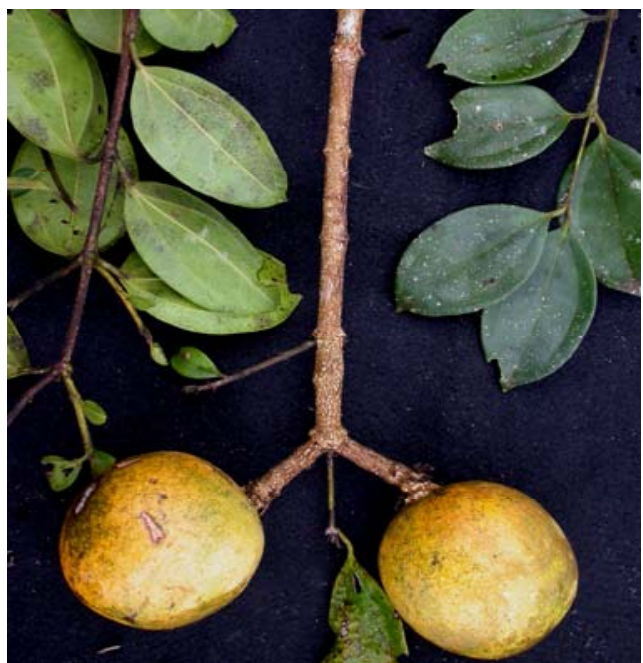

Strychnos trinervis (Vell.) Mart. DICA DE CAMPO

Esta espécie pode ser caracterizada por apresentar caule com espinhos e gavinhas com porção apical espessa. Além disso, as folhas são elípticas e triplinérveas.

\section{Malpighiaceae}

Família distribuída pelas regiões tropicais e subtropicais do mundo, principalmente no continente americano, onde é seu centro de diversidade. É um grupo composto por cerca de 68 gêneros e 1.250 espécies, dos quais 44 gêneros e 800 espécies ocorrem nas Américas. Na área de estudo foram encontradas 4 espécies de lianas.

As Malpighiaceae são facilmente reconhecidas em estado vegetativo por apresentar folhas simples, opostas, com margem inteira e tricomas do tipo malpiguiáceo (com a forma de “T”). Apresentam, em geral, estípulas intrapeciolares, as quais podem ser caducas nas lianas. A presença de glândulas na base das folhas ou no pecíolo é freqüente, sendo este um caráter diagnostico, pois é a única família de lianas na área com folhas opostas que apresenta esta característica. As flores são facilmente reconhecidas por apresentarem um par de nectários em cada sépala.

\section{CHAVE DE IDENTIFICAÇÃO}

1. Estípulas não unidas ao pecíolo; indumento denso na face abaxial das folhas

2. Face abaxial com indumento de coloração dourada. Heteropterys nitida

2'. Face abaxial com indumento de coloração branca Banisteriopsis argyrophylla

1'. Estípulas unidas ao pecíolo; face abaxial das folhas com poucos tricomas

3. Folhas lanceoladas com ápice agudo a acuminado Hiraea sp. 1 3’. Folhas oblanceoladas com ápice obtuso .... Hiraea sp. 2 


\section{Malpighiaceae}

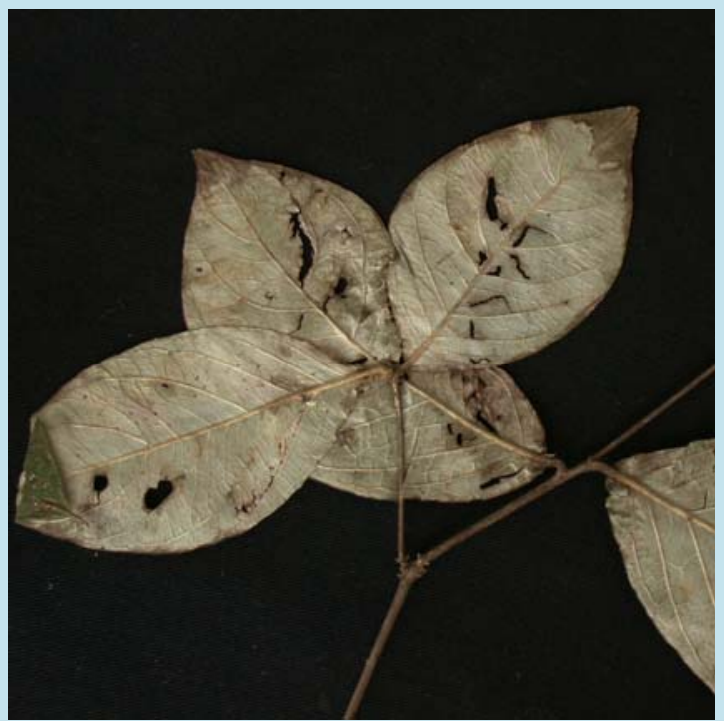

Banisteriopsis argyrophylla (A. Juss.) B. Gates

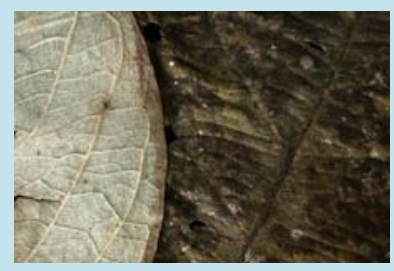

Folhas: face abaxial e adaxial

\section{DICA DE CAMPO}

Espécie de fácil reconhecimento no campo por apresentar a face inferior das folhas com indumento branco.

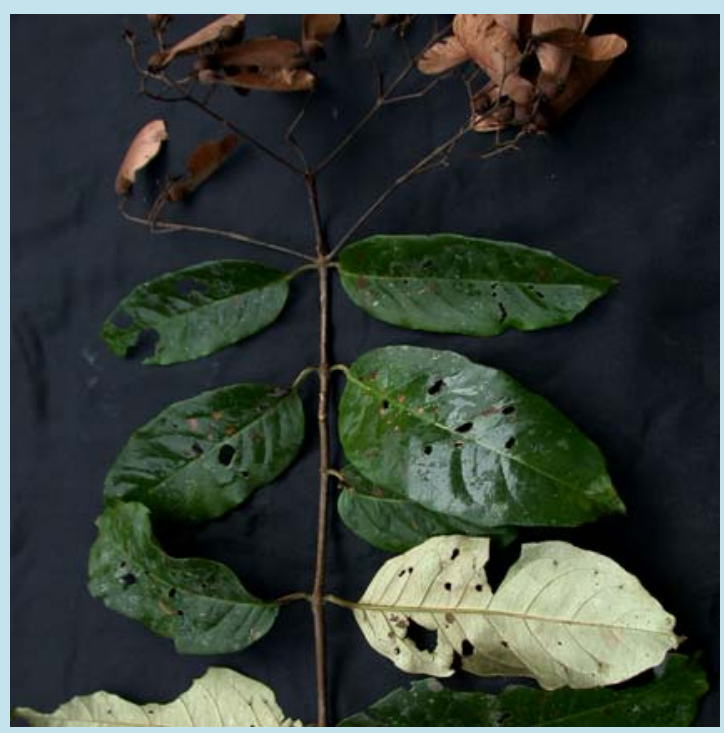

Heteropterys nitida (Lamark) DC.

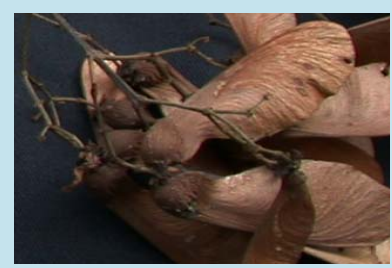

Frutos

\section{DICA DE CAMPO}

Espécie caracterizada por apresentar a face inferior das folhas douradas. 


\section{Malpighiaceae}

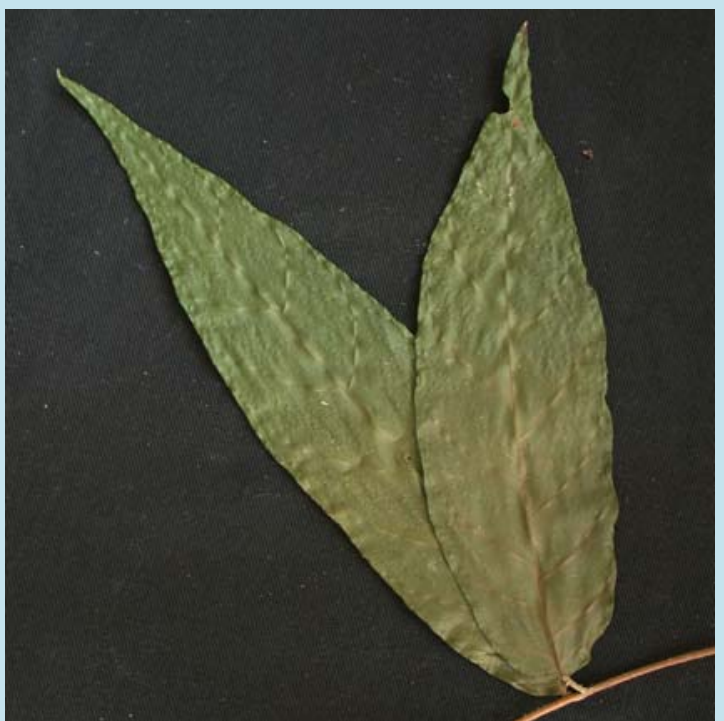

Hiraea sp. 1

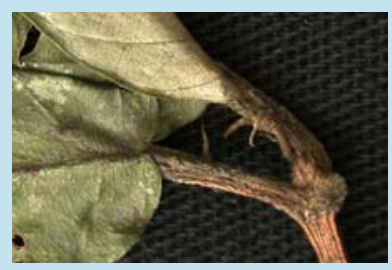

Estípulas unidas ao pecíolo

\section{DICA DE CAMPO}

Apresenta folhas lanceoladas com ápice agudo a acuminado.

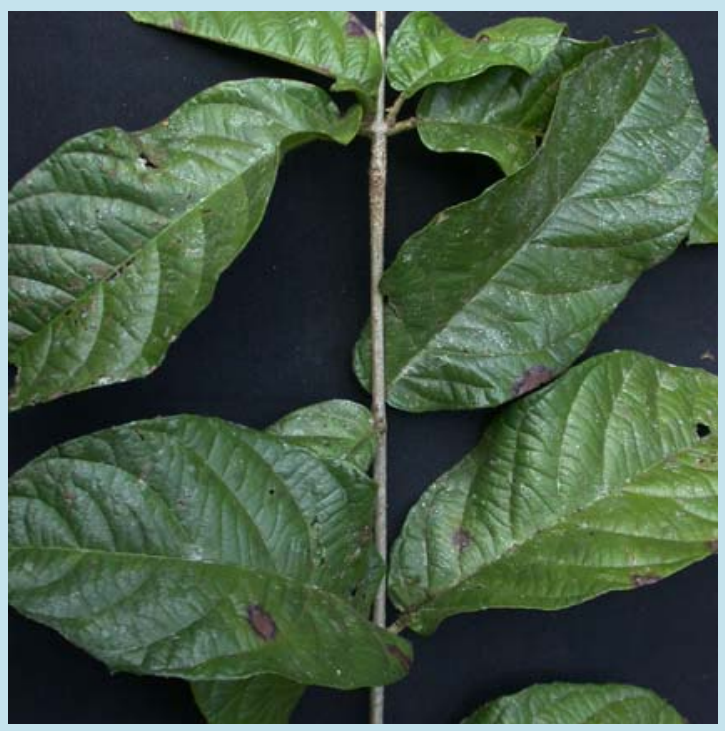

Hiraea sp. 2

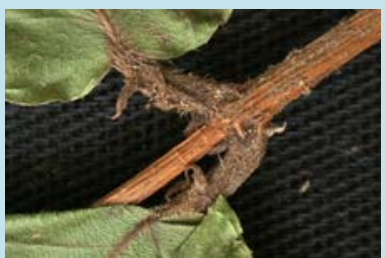

Estípulas unidas ao pecíolo

\section{DICA DE CAMPO}

Pode ser diferenciada da outra espécie de Hiraea por apresentar folhas oblanceoladas com ápice obtuso. 


\section{Menispermaceae}

Família predominantemente de lianas, com distribuição pantropical. É representada por 420 espécies, distribuídas por 70 gêneros. Nos neotrópicos existem 17 gêneros e 187 espécies. Na área estudada foram registradas duas espécies, Abuta selloana e Cissampelos andromorpha.

São lianas sem gavinhas, que apresentam folhas alternas, simples, com venação palmada e não apresentam estípulas; o pecíolo é alongado com pulvino engrossado no ápice e na base. As flores são pequenas, de coloração verde, alvacenta, amarela ou marrom (raramente rosa), unissexuais, em geral trímeras. Apresentam pétalas menores que as sépalas e o fruto é drupáceo. Em geral as folhas são decíduas e é comum que as flores apareçam em ramos áfilos.

\section{CHAVE DE IDENTIFICAÇÃO}

1. Folhas glabras, ovadas; ápice do pecíolo espessado Abuta selloana

1'. Folhas pubérulas, largamente ovadas; ápice do pecíolo não espessado

\section{Cissampelos andromorpha}

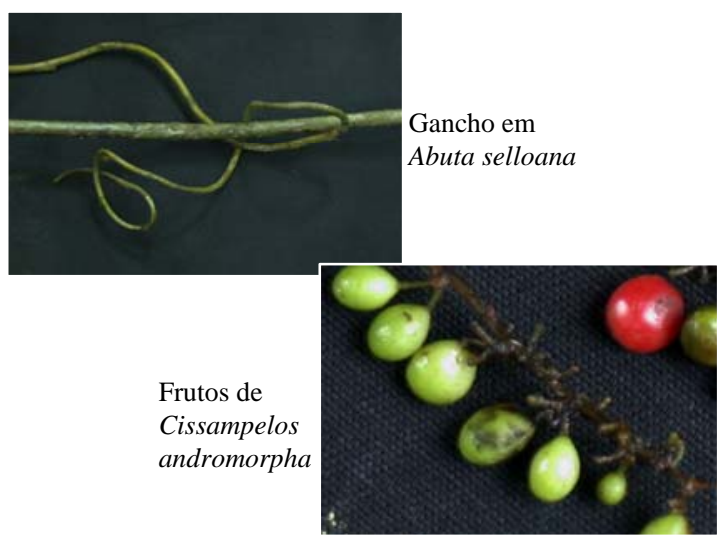

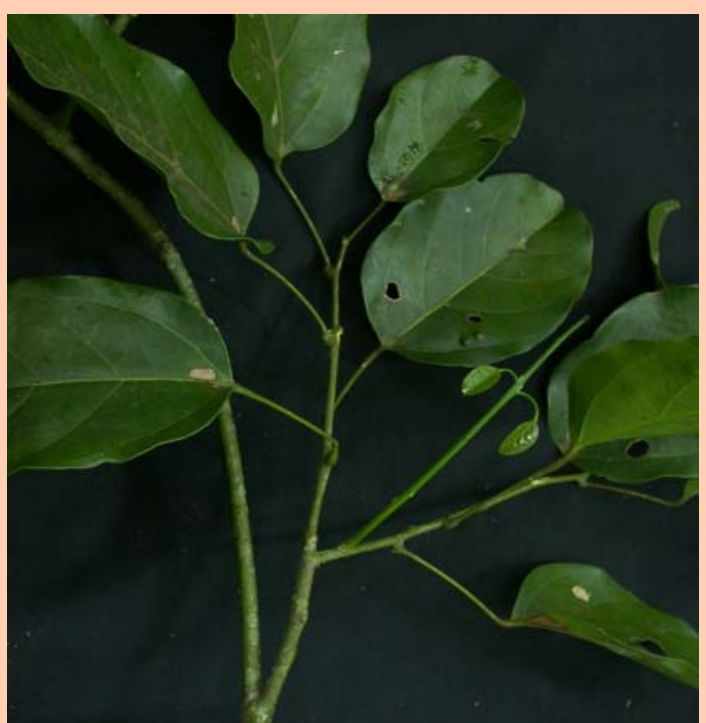

Abuta selloana Eichler

\section{DICA DE CAMPO}

Planta volúvel, com longos pecíolos (em geral maiores que $5 \mathrm{~cm}$ ) e folhas glabras, 3-nervadas. O caule apresenta modificações em forma de gancho.

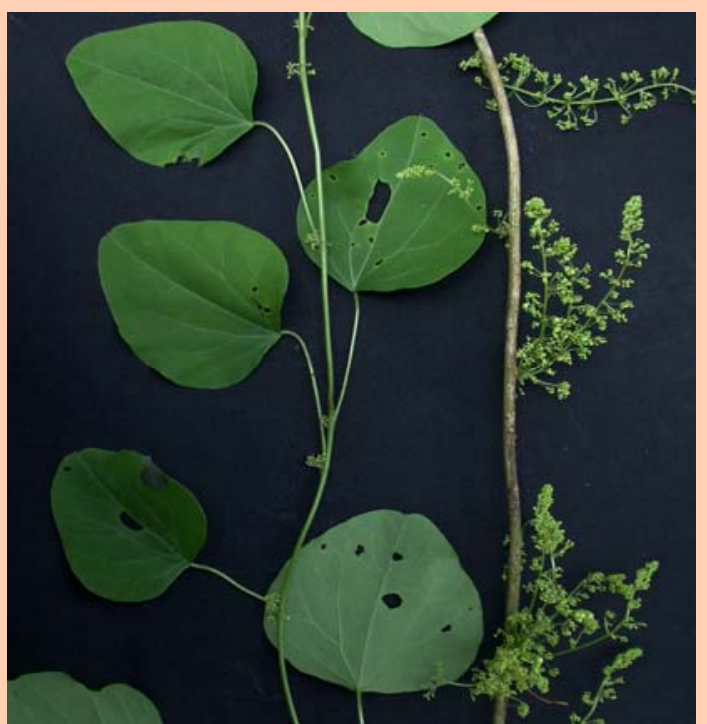

Cissampelos andromorpha DC.

\section{DICA DE CAMPO}

Nessa espécie as folhas são largamente ovadas e o caule não apresenta modificações em forma de gancho. 


\section{Phytolaccaceae}

Phytolaccaceae é uma família relativamente pequena, com 17 gêneros e cerca de 80 espécies, distribuídas principalmente pela América do Sul tropical e subtropical. Na área de estudo foi encontrada um única espécie com hábito lianescente, Seguieria floribunda.

São árvores, lianas, arbustos ou ervas. As folhas são simples e alternas. As flores são dióicas, monoclamídeas e com gineceu sincárpico; os frutos são bagas.

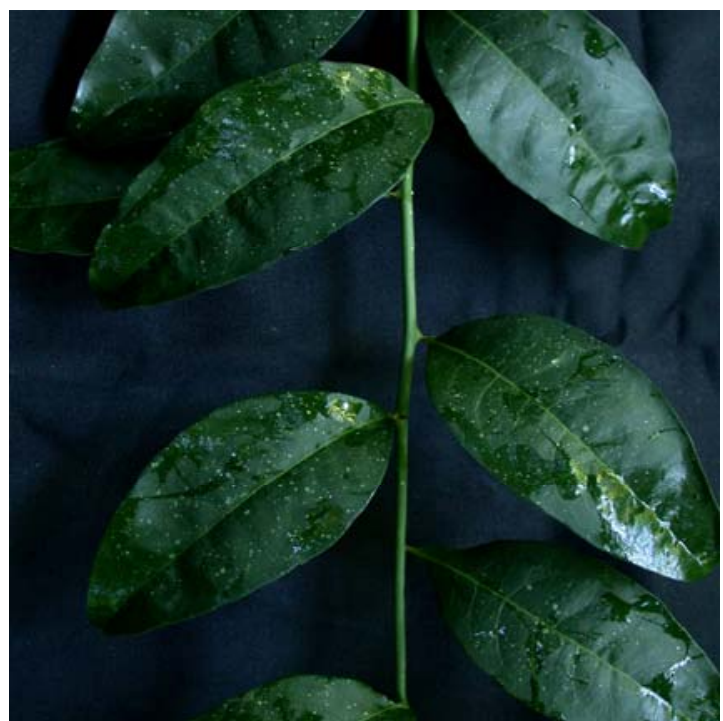

Seguieria floribunda Benth.

\section{DICA DE CAMPO}

Dentre as plantas com folhas simples, é a única que apresenta 2 espinhos na base dos ramos laterais.

\section{Polygonaceae}

Família cosmopolita, distribuída principalmente nas zonas temperadas. Contém aproximadamente 1150 espécies, distribuídas por 51 gêneros. Na área de estudo foi encontrada uma única espécie, Coccoloba cf. parimensis.

A família inclui árvores, arbustos, ervas e lianas. As folhas são simples e alternas, com margem inteira. O pecíolo é envolvido por uma ócrea.

As Polygonaceae, em geral, são dióicas, com flores reduzidas, dispostas numa espiga ou racemo, geralmente axilar. Em Coccoloba as flores são muito reduzidas, com 5 tépalas. Os frutos são globosos, alados ou triangulares.

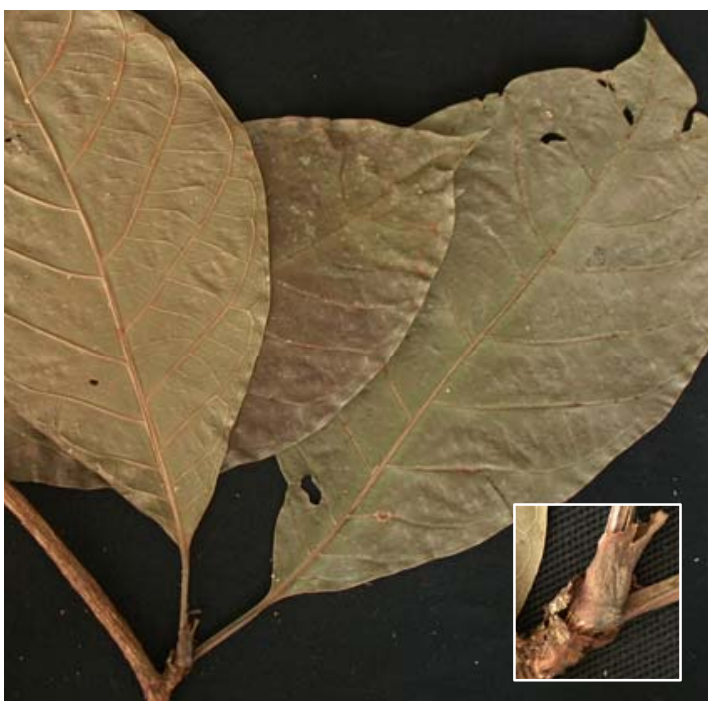

Coccoloba cf. parimensis Benth.

\section{DICA DE CAMPO}

Única espécie encontrada na área de estudo que apresenta ócrea. 


\section{Sapindaceae}

Família com 135 gêneros e cerca de 1.500 espécies distribuídas pelas regiões tropicais e subtropicais, com poucas espécies ocorrendo em áreas de clima temperado. Na área abrangida pelo estudo foram encontradas 3 espécies de lianas pertencentes ao gênero Paullinia, o qual é o segundo maior da família, com cerca de 200 espécies.

São arbustos, árvores ou lianas, as quais podem ser herbáceas ou lenhosas, com folhas alternas e gavinhas bífidas (nas lianas). As flores são pequenas, brancas ou amarelas, com pedicelo articulado e presença de disco nectarífero. Os frutos podem ser deiscentes ou indeiscentes, secos ou carnosos, às vezes alados, com sementes freqüentemente ariladas.

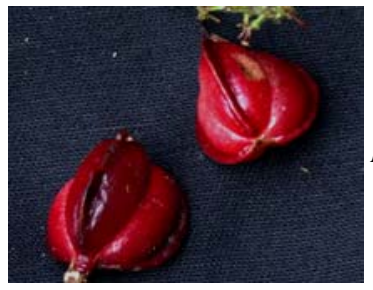

Paullinia meliifolia: frutos

\section{CHAVE DE IDENTIFICAÇÃO}

1. Planta com caule e folhas providos de indumento hirsuto ..................Paullinia meliifolia

1'. Planta com caule e folhas providos de indumento esparso

2. Raque foliar com alas muito evidentes com 0,7-1,0cm de largura e domácias inconspícuas ............. Paullinia carpopoda

2'. Raque foliar com alas pouco evidentes, não ultrapassando $0,3 \mathrm{~cm}$ de largura e domácias conspícuas ..... Paullinia trigonia

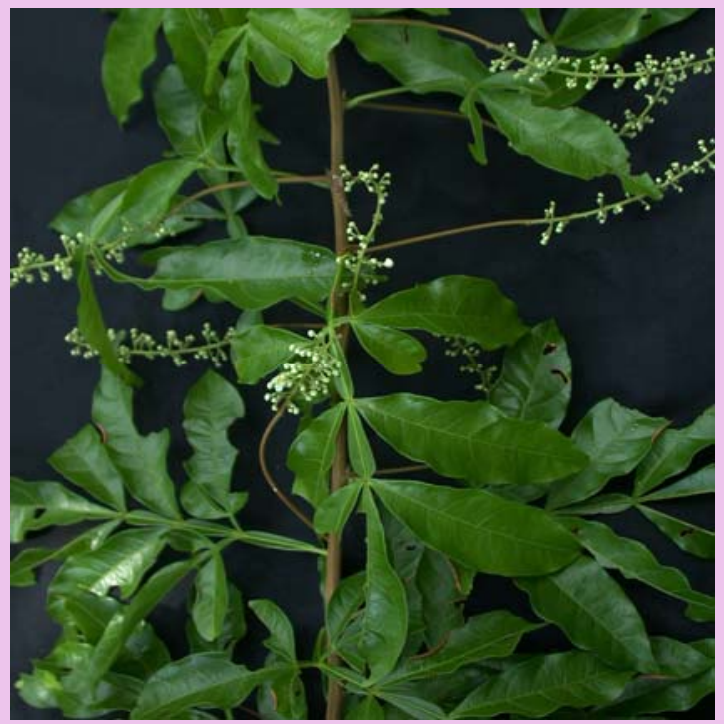

Paullinia carpopoda Cambess.

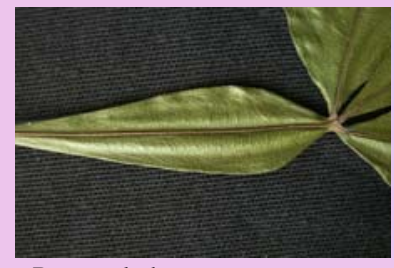

Raque alada

\section{DICA DE CAMPO}

Espécie facilmente reconhecida por apresentar raque foliar com alas muito evidentes (0,7-1,0 cm de largura), diferindo de $P$. meliifolia por não apresentar indumento hirsuto. 


\section{Sapindaceae}

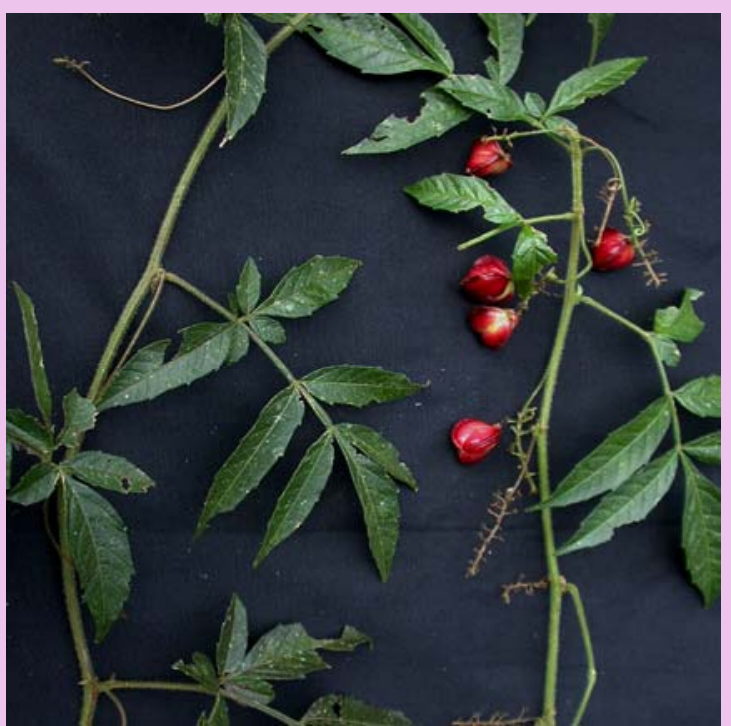

Paullinia meliifolia Juss.

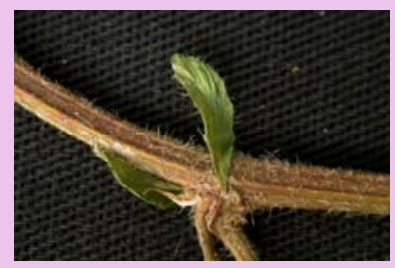

Estípulas foliáceas

\section{DICA DE CAMPO}

Esta espécie apresenta caule e folhas providos de indumento hirsuto e a raque foliar com alas bem evidentes. Uma característica importante para seu reconhecimento é a presença de estípulas foliáceas.

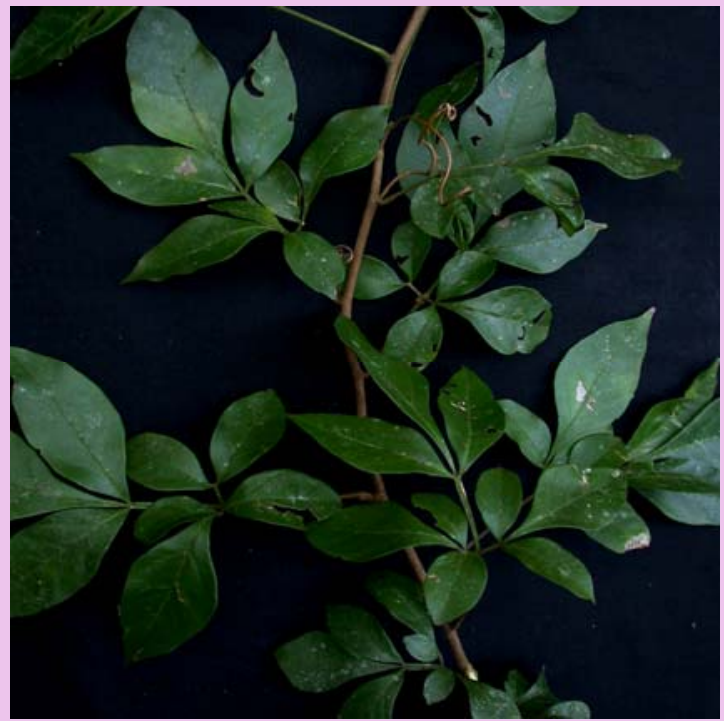

Paullinia trigonia Vell.

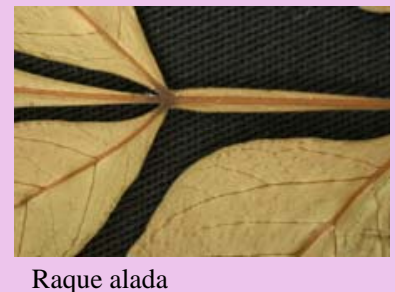

DICA DE CAMPO

Tanto o caule quanto as folhas são providos de poucos e esparsos tricomas. As folhas apresentam alas estreitas. 
Família cosmopolita, contendo 830 espécies, distribuídas por 23 gêneros. Nos neotrópicos, os maiores gêneros são Hybanthus e Rinorea. Na área de estudo foi encontrado um único representante, Anchietea pyrifolia, única liana da família que ocorre em São Paulo.

Podem ser árvores, arvoretas, arbustos, ervas e lianas (apenas Anchietea, Corynostylis e Hybanthopsis). As folhas são simples, com margem inteira a levemente serrilhada, algumas espécies com pontuações e estípulas, às vezes, caducas. As flores são pentâmeras, normalmente bissexuais, solitárias e axilares ou em racemos, panículas ou tirsos. O fruto é uma cápsula trivalvar, ou mais raramente uma noz indeiscente e globosa (Leonia). As sementes são freqüentemente ariladas ou aladas.

Família com distribuição pantropical e temperada (nas regiões mais quentes), compreende 14 gêneros e cerca de 850 espécies. $\mathrm{Na}$ área de estudo é representada por uma espécie: Cissus verticillata.

Grupo formado por lianas de fácil reconhecimento, mesmo em estado vegetativo, pois apresentam gavinhas opostas às folhas. Apresentam estípulas na base do pecíolo geralmente decíduas, margem foliar com apículos provindos das nervuras secundárias ou terciárias e ápice mucronado.

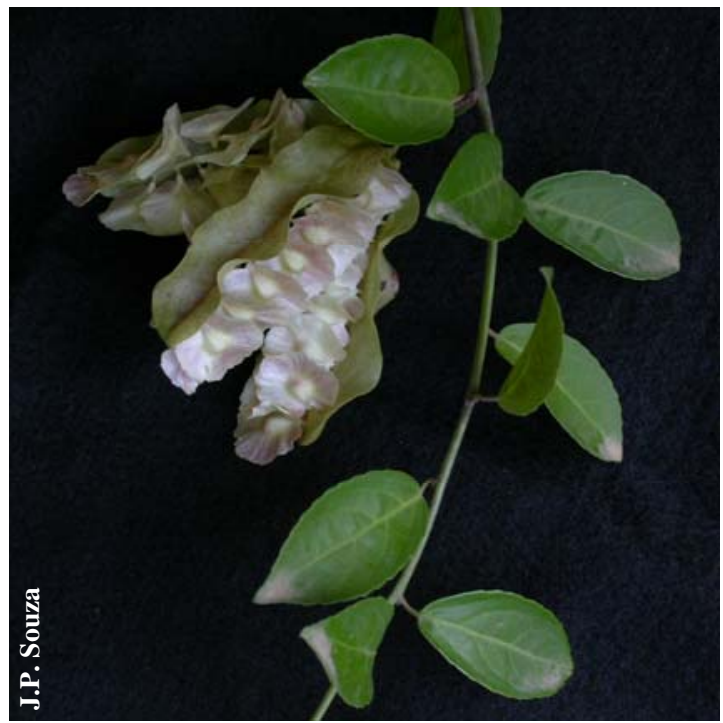

Anchietea pyrifolia (Mart.) G. Don

\section{DICA DE CAMPO}

Apresenta folhas com margem serrilhada e pontuações lustrosas na face abaxial.

\section{Vitaceae}

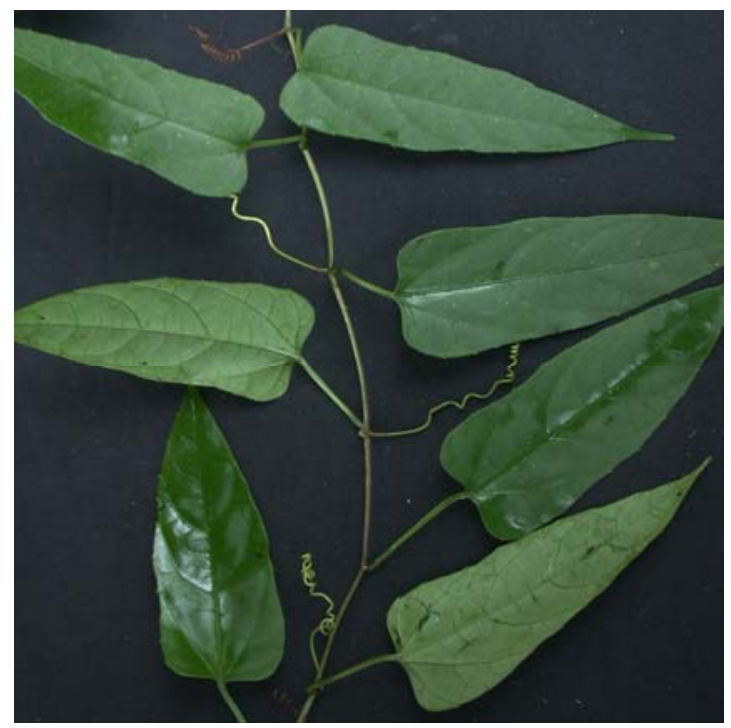

Cissus verticillata (L.) Nicolson \& C.E. Jarvis

\section{DICA DE CAMPO}

Espécie de fácil reconhecimento, pois apresenta gavinhas opostas às folhas. 


\section{REFERÊNCIAS BIBLIOGRÁFICAS}

BENZING, D.H. Vascular epiphytes: general biology and related biota. New York: Cambridge University Press, 1990. 354p.

BERNACCI, L.C.; LEITÃO FILHO, H.F. Flora fanerogâmica da fazenda São Vicente, Campinas, SP. Revista Brasileira de Botânica, v.19, n.2, p.149-164, 1996.

CAIN, S.A.; CASTRO, G.M. Manual of vegetation analysis. New York: Harper, 1959. 325p.

CAMARGO, M.N.; KLAMT, E.; KAUFFMAN, J.H. Sistema brasileiro de classificação de solos. Boletim Informativo da Sociedade Brasileira de Ciência do Solo, v.12, n.1, p.11-33, 1987.

CROAT, T. Flora of Barro Colorado Island. California: Standford University Press, 1978. 943p.

CRONQUIST, A. An integrated system of classification of flowering plants. New York: Columbia University Press, 1981. 1262p. 
DARWIN, C. The different forms of flowers on plants of the same species. Chicago: University of Chicago Press, 1867. 352p.

DOMINGUES, E. N.; SILVA, D. A. Geomorfologia do Parque Estadual de Carlos Botelho (SP). Boletim Técnico do Instituto Florestal, v.42, p.71-105, 1988.

EMMONS, L.H.; GENTRY, A.H. Tropical struture and the distribution of gliding and prehensile vertebrates. The American Naturalist, v.121, n.4, p.513-524, 1983.

ENGEL, V.L.; FONSECA, R.C.B.; OLIVEIRA, R.E. Ecologia de lianas e o manejo de fragmentos florestais. Série Técnica IPEF, v.12, n.32, p. 43-64, 1998.

GENTRY, A.H. An ecotaxonomic survey of panamanian lianas. In: ARCY, W.G.D.; CORREA, M. Historia Natural de Panama. St. Louis: Missouri Botanical Garden, 1985. p.29-42.

GENTRY, A.H. The distribution and evolution of clibing plants. In: PUTZ, F.E.; MOONEY, H.A. The biology of vines. Cambridge: Cambridge University Press, 1991. p.3-49.

GENTRY, A.H.; DODSON, C. Contribution of nontrees to species richness of a tropical rain forest. Biotropica, v.19, n.2, p.149-156, 1987.

GIVNISH, T.J.; VERMEIJ, G.J. Sizes and shapes of liane leaves. The American Naturalist, v.110, p.743-748, 1976. 
GROMBONE, M.T.; BERNACCI, L.C.; MEIRA NETO, J.A.A.; TAMASHIRO, J.Y.; LEITÃO FILHO, H.F. Estrutura fitossociologica da floresta semidecídua de altitude do Parque Municipal da Grota Funda (Atibaia - Estado de São Paulo). Acta Botanica Brasílica, v.4, n.2, p.47-64, 1990.

HALL, J.B.; SWAINE, M.D. Classification and ecology of closed-canopy tropical forest in Ghana. Journal of Ecology, v.64, p.913-951, 1976.

HEGARTY, E.E. Vine-host interactions. In: PUTZ, F.E.; MOONEY, H.A. The biology of vines. Cambridge: Cambridge University Press, 1991. p.357-375.

HEGARTY, E.E.; CABALLÉ, G. Distribution and abundance of vines in forest communities. In: PUTZ, F.E.; MOONEY, H.A. The biology of vines. Cambridge: Cambridge University Press, 1991. p.313-335.

HORA, R.C. Composição florística e aspectos da estrutura da comunidade de lianas em uma mata mesófila semidecídua na Fazenda Canchim, São Carlos - SP. São Carlos, 1999. 86p. Dissertação (Mestrado) - Universidade Federal de São Carlos.

JACOBS, M. The study of lianas. Flora Malesiana Bulletin, v.29, 2610-2618, 1976.

KELLY, D.L. Epiphytes and climbers of a Jamaican rain forest: vertical distribution, life forms and life histories. Journal of Biogeography, v.12, p.223-241, 1985. 
KIM, A.C., Lianas da mata atlântica do Estado de São Paulo. Campinas, 1996. 211p. Dissertação (Mestrado) - Universidade Estadual de Campinas.

KÖEPPEN, W. Climatologia. México: Ed. Fundo de Cultura Econômica, 1948. 478 p.

LEE, D.W.; RICHARDS, J.H. Heteroblastic development in vines. In: PUTZ, F.E.; MOONEY, H.A. The biology of vines. Cambridge: Cambridge University Press, 1991. p.205-243.

LEITÃO FILHO, H.F. A vegetação da reserva de Santa Genebra. In: MORELLATO, P.C.; LEITÃO FILHO, H.F. (Org.) Ecologia e preservação de uma floresta tropical urbana, Reserva de Santa Genebra, Campinas: Ed. UNICAMP, 1995. p.19-29.

LIEBERMAN, M.; LIEBERMAN, D.; HARTSHORN, G.S.; PERALTA, R. Smallscale altitudinal variation in lowland wet tropical forest vegetation. Journal of Ecology, v.73, p.505-516, 1985.

LIMA, H.C.; LIMA, M.P.M.; VAZ, A.M.S.; PESSOA, S.V.A. Trepadeiras da reserva ecológica de Macaé de Cima. In: LIMA, H.C.; GUEDES-BRUNINI, R.R. Serra de Macaé de Cima: diversidade florística e conservação em Mata Atlântica. Rio de Janeiro: Jardim Botânico do Rio de Janeiro, 1997. p.75-87.

LOMBARDI, J.A.; GONÇALVES, M. Composição florística de dois remanescentes de Mata Atlântica do sudeste de Minas Gerais, Brasil. Revista Brasileira de Botânica, v.23, n.3, p.255-288, 2000. 
MAIA, L.M. de A. Aspectos fitossociológicos de lianas em mata de terra firme, Manaus, Amazonas. Manaus, 1990. 114p. Dissertação (Mestrado) - Instituto Nacional de Pesquisas da Amazônia.

MATTOS, I. F.A.; ROSSI, M.; SILVA, D.A.; PFEIFFER, R.M. Levantamento do meio biofísico e avaliação da fragilidade do ecossistema na Estação Ecológica dos Caetetus, SP. Sociedade e Natureza, v.15, p.388-393, 1996.

MENNINGER, E.A. Flowering vines of the world: an encyclopedia of climbing plants. New York: Hearthside Press Incorporated, 1970. 410p.

MORELLATO, L.P.C. Fenologia de árvores, arbustos e lianas de uma floresta semidecídua no sudeste do Brasil. Campinas, 1991. 236p. Tese (Doutorado) - Universidade Estadual de Campinas.

MORELLATO, L.P.C.; LEITÃO FILHO, H.F. Reproductive phenology of climbers in a southeasthern brazilian forest. Biotropica, v.28, n.2, p.180-191, 1996.

MORELLATO, L.P.C.; LEITÃO FILHO, H.F. Levantamento florístico da comunidade de trepadeiras de uma floresta semidecídua no sudeste do Brasil. Boletim do Museu Nacional, Nova Série, Botânica, n.103, p.1-15, 1998.

NEGREIROS, O.C. Características fitossociológicas de uma floresta latifoliolada pluviosa tropical visando ao manejo do palmito, Euterpe edulis Mart. Piracicaba, 1982. 104p. Dissertação (Mestrado) - Escola Superior de Agricultura “Luiz de Queiroz”, Universidade de São Paulo. 
OPLER, P.A.; BAKER, H.G.; FRANKIE, G.W. Seasonality of climber comunities: a review and example from Costa Rica dry forest. In: PUTZ, F.E.; MOONEY, H.A. The biology of vines. Cambridge: Cambridge University Press, 1991. p.377-391.

PAGANO, S.N.; LEITÃO FILHO, H.F. Composição florística do estrato arbóreo de mata mesófila semidecídua, no município de Rio Claro (Estado de São Paulo). Revista Brasileira de Botânica, v.10, p.37-47, 1987.

PEÑALOSA, J. Basal branching and vegetative spread in two tropical rainforest lianas. Biotropica, v.16, n.1, p.1-9, 1984.

PILIACKAS, J.M. Fitossociologia da comunidade epífita vascular do manguezal do Rio das Bicas por meio da análise de imagens digitalizadas (Picinguaba, Ubatuba, São Paulo, SP). Rio Claro, 2001. 113p. Tese (Doutorado) - Instituto de Biociências, Universidade Estadual Paulista "Júlio de Mesquita Filho".

PRANCE, C.T. A comparison of the efficacy of higher taxa and species numbers in the assessment of biodiversity in the neotropics. Philosophical Transaction of the Royal Society of London. Series B, v. 345, p.89-99, 1994.

PUTZ, F.E. The natural history of lianas on Barro Colorado Island, Panama. Journal of Ecology, v.65, n.6, p.1713-1724, 1984.

PUTZ, F.E.; CHAI, P. Ecological studies of lianas in Lambir National Park, Sarawak. Journal of Ecology, v.75, p.523-531, 1987. 
PUTZ, F.E.; WINDSOR, D.M. Liana phenology on Barro Colorado Island, Panama. Biotropica, v.19, n.4, p.334-341, 1987.

REZENDE, A.A. Levantamento florístico das espécies de lianas da estação ecológica do Noroeste Paulista - São José do Rio Preto / Mirassol, SP, chave de identificação e diagnoses. Campinas, 1997. 99p. Dissertação (Mestrado) Universidade Estadual de Campinas.

RIBEIRO, J.E.L.S.; HOPKINS, M.J.G.; VICENTINI, A.; SOTHERS, C.A.; COSTA, M.A.S.; BRITO, J.M.; SOUZA, M.A.D.; MARTINS, L.H.P.; LOHMANN, L.G.; ASSUNÇÃO, P.A.C.L.; PEREIRA, E.C.; SILVA, C.F.; MESQUITA, M.R.; PROCÓPIO, L.C. Flora da Reserva Ducke: guia de identificação das plantas vasculares de uma floresta de terra-firme na Amazônia Central. Manaus: INPA,1999. 816p.

RICHARDS, P.W. The Tropical Rain Forest. Cambridge: Cambridge University Press, 1952. 450p.

RODRIGUES, R.R.; MORELLATO, L.P.C.; JOLY, C.A.; LEITÃO FILHO, H.F. Estudo florístico e fitossociológico em um gradiente altitudinal de mata estacional mesófila semidecídua, na Serra do Japi, Jundiaí, SP. Revista Brasileira de Botânica, v.12, p.71-84, 1989.

SCHNITZER, S.A,; CARSON, W.P. Treefall gaps and the maintenance of species diversity in a tropical forest. Ecology, v.82, n.4, p.913-919, 2001.

SETZER, J. Contribuição para o estudo do clima do Estado de São Paulo. São Paulo: Escolas Profissionais Salesianas, 1946. 239p. 
SILVA, A.F.; LEITÃO FILHO, H.F. Composição florística e estrutura de um trecho de mata atlântica de encosta no município de Ubatuba (São Paulo, Brasil). Revista Brasileira de Botânica , v.5, p.43-52, 1982.

STEVENS, G.C. Lianas as structural parasites: the Bursera simaruba example. Journal of Ecology, v.68, n.1, p.77-81, 1987.

TABARELLI, M.; MANTOVANI, W. A riqueza de espécies arbóreas na floresta atlântica de encosta no Estado de São Paulo (Brasil). Revista Brasileira de Botânica, v.22, n.2, p.217-223, 1999.

UDULUTSCH, R.G. Composição florística da comunidade de lianas em uma floresta estacional semidecidual, Rio Claro, São Paulo. Rio Claro, 2001. 60p. Monografia (Graduação) - Instituto de Biociências, Universidade Estadual Paulista "Júlio de Mesquita Filho".

VELOSO, H. P. Sistema fitogeográfico. In: FUNDAÇÃO INSTITUTO BRASILEIRO DE GEOGRAFIA E ESTATÍSTICA. Manual Técnico da Vegetação Brasileira. Rio de Janeiro: IBGE, 1992. p.9-38. (Manuais Técnicos em Geociências, 1).

VELOSO, H.P.; GÓES-FILHO, L. Fitogeografia brasileira: classificação fisionômico-ecológica da vegetação neotropical. In: MINISTÉRIO DAS MINAS E ENERGIA. Boletim Técnico do Projeto RADAMBRASIL (Série Vegetação). Salvador: IBGE, 1982. p.1- 86. 
WAECHTER, J.L.O epifitismo vascular na planície costeira do Rio Grande do Sul. São Carlos, 1992. 161p. Tese (Doutorado) - Universidade Federal de São Carlos. 


\section{BIBLIOGRAFIA RECOMENDADA}

CRONQUIST, A. An integrated system of classification of flowering plants. New York: Columbia University Press, 1981. 1262p.

GENTRY, A.H. The distribution and evolution of clibing plants. In: PUTZ, F.E.; MOONEY, H.A. The biology of vines. Cambridge: Cambridge University Press, 1991.

HORA, R.C. Composição florística e aspectos da estrutura da comunidade de lianas em uma mata mesófila semidecídua na Fazenda Canchim, São Carlos - SP. São Carlos, 1999. 86p. Dissertação (Mestrado) - Universidade Federal de São Carlos.

JUDD, W.S.; CAMPBELL, C.S.; KELLOGG, E.A.; STEVENS, P.F. Plant Systematics: a phylogenetic approach. Sunderland: Sinauer Associates, 1999. 464p.

KIM, A.C., Lianas da mata atlântica do Estado de São Paulo. Campinas, 1996. 211p. Dissertação (Mestrado) - Universidade Estadual de Campinas. 
MORELLATO, L.P.C.; LEITÃO FILHO, H.F. Levantamento florístico da comunidade de trepadeiras de uma floresta semidecídua no Sudeste do Brasil. Boletim do Museu Nacional, Nova Série, Botânica, n.103, p.1-15, 1998.

REZENDE, A.A. Levantamento florístico das espécies de lianas da Estação Ecológica do Noroeste Paulista - São José do Rio Preto / Mirassol, SP, chave de identificação e diagnoses. Campinas, 1997. 99p. Dissertação (Mestrado) Universidade Estadual de Campinas.

RIBEIRO, J.E.L.S.; HOPKINS, M.J.G.; VICENTINI, A.; SOTHERS, C.A.; COSTA, M.A.S.; BRITO, J.M.; SOUZA, M.A.D.; MARTINS, L.H.P.; LOHMANN, L.G.; ASSUNÇÃO, P.A.C.L.; PEREIRA, E.C.; SILVA, C.F.; MESQUITA, M.R.; PROCÓPIO, L.C. Flora da Reserva Ducke: guia de identificação das plantas vasculares de uma floresta de terra-firme na Amazônia Central. Manaus: INPA,1999. 816p.

STEVENS, P.F. /www.mobot.org/MOBOT/Research/Apweb/welcome.html/ 15 de maio de 2002 - University of Missouri, St. Louis, and Missouri Botanical Garden. (26 DEC. 2002).

UDULUTSCH, R.G. Composição florística da comunidade de lianas em uma floresta estacional semidecidual, Rio Claro, São Paulo. Rio Claro, 2001. 60p. Monografia (Graduação) - Instituto de Biociências, Universidade Estadual Paulista "Júlio de Mesquita Filho". 